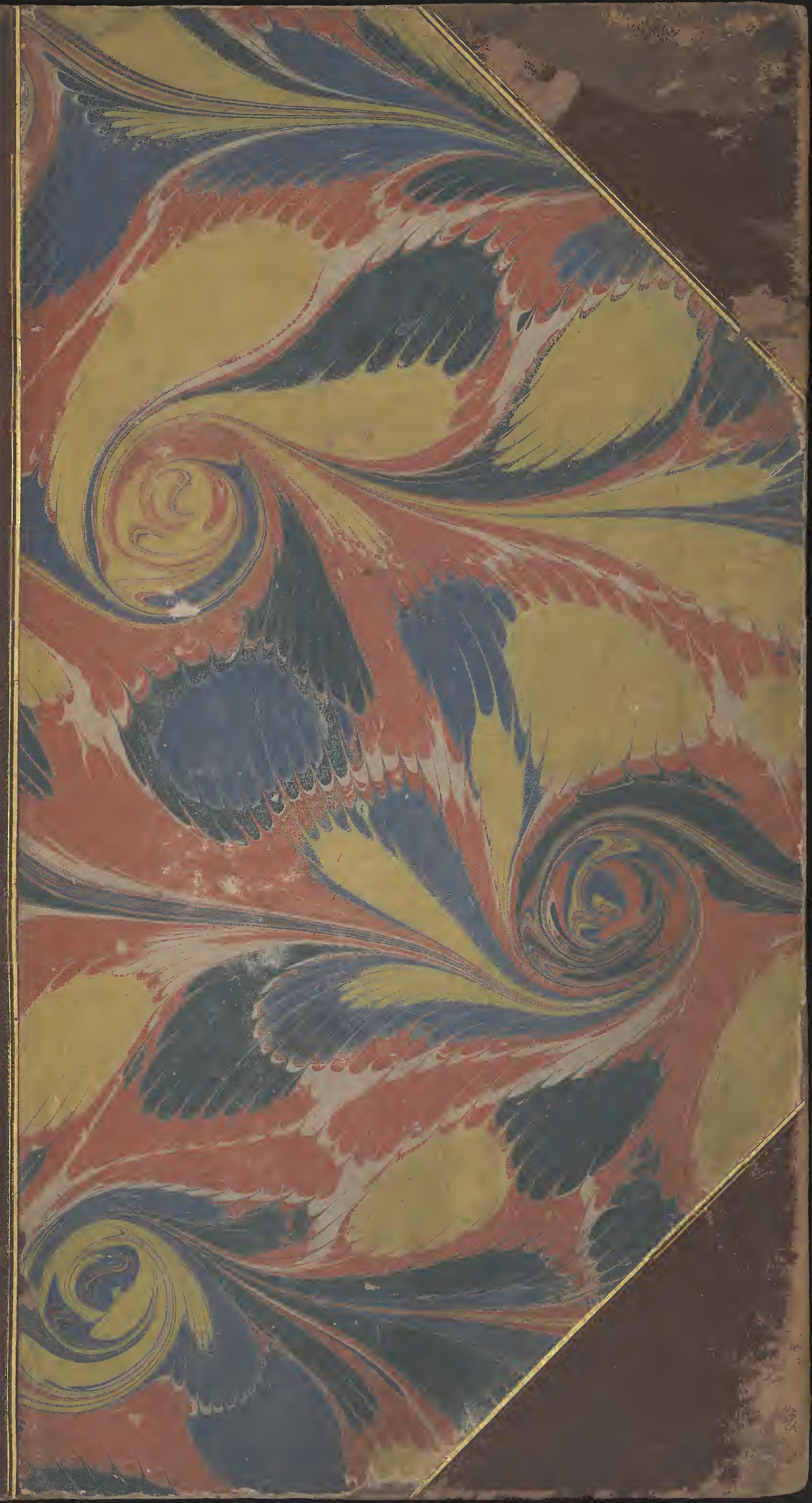


D) surger.

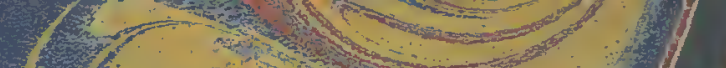




$$
30
$$




\section{Hllustrations and 伊scriptions}

oF

\section{THE PLANTS}

WHICH COMPOSE THE NATURAL ORDER

\section{CA M E L L I E $\not \mathbf{E}$,}

AND OF

THE VARIETIES OF

\section{A M EII I JAPO N I A,}

Cultiluated in the Garions of Great loritain.

THE DRAWINGS BY ALFRED CHANDLER.

THE DESCRIPTIONS BY WILLIAM BEATTIE BOOTH, A.L.S.

\section{Lonion:}

PUBLISHED BY JOHN AND ARTHUR ARCH, CORNHILL. PRINTED BY C. BAYNES, DUKE STREET, LINCOLN'S INN FIELDS.

1831. 


\section{PRE FA C E.}

The First Volume of this Work is now respectfully submitted to the Public. It contains illustrations of five species of Camellia, sixteen varieties of Camellia Japonica, which have been imported from China, and nineteen selected from those which have been raised from seed in this country; accompanied by a minute description of each, and a history, as far as we could ascertain, of their introduction and origin; all of which, we trust, will be found satisfactory and correct.

In addition to the above, we have endeavoured to redeem our promise at folio 6 , by giving, at the end of the volume, a succinct account of the fittest compost for Camellias, and of the most approved methods for their propagation and treatment. This, it is hoped, will make the volume complete in itself, and, at the same time, render it independent of the second one; the publication of which, from several unforeseen events, we are reluctantly obliged to postpone for the present. We cannot, however, allow the present opportunity to pass, without 
acknowledging our obligations to those who have honoured the Work with their patronage and support. At a future time, we trust again to appear before the Public, and hope our labours will meet with the same flattering encouragement.

A. CHANDLER.

W. B. BOOTH.

Loudon, November 1, 1831. 


\section{CONTENTS.}

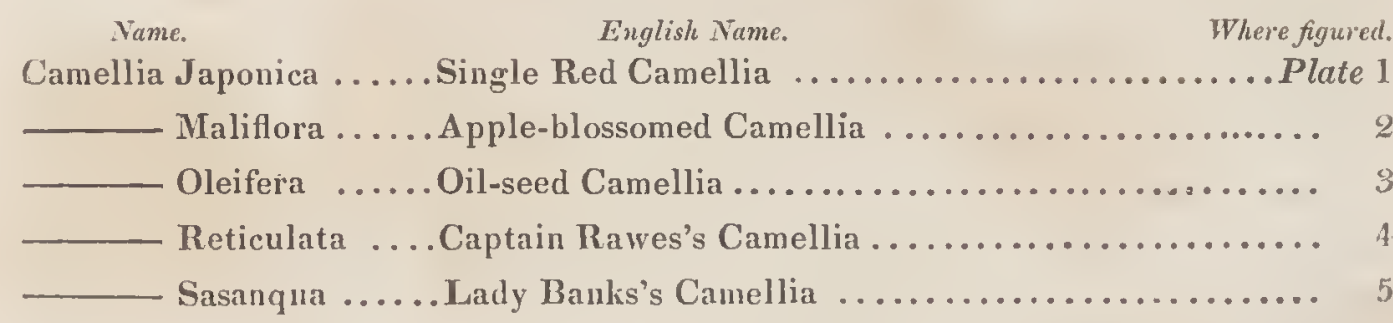

CHINESE VARIETIES OF CAMELLIA JAPONICA.

Alba semiduplex .......Palmer's Semi-double White Camellia ........... 33

— flore pleno ....... Double White Camellia ................... 11

Anemoniflora .........Anemone-flowered, or Waratáh Camellia ......... 8

Atro-rubens ..........Loddiges's Red Camellia ................... 25

Rosea ..............Middlemist's Red Camellia.................. 29

Crassinervis ...........Mr. Kent's Camellia....................... 39

Fimbriata ............ Fringed Double Wlite Camellia............... 15

Imbricata ............ Crimson Shell-flowered Camellia.............. 22

Incarnata ............Lady Hume's Blush Camellia ............... 7

Myrtifolia............Myrtle-leaved Camellia .................. 14

Pæoniflora rosea........Red Pæony-flowered Camellia ................ 19

Pomponia ............Pompone Camellia ..................... 9

Rubra plena.......... Double Red Camellia .................... 18

Speciosa.............Captain Rawes's variegated Waratáh Camellia ..... 32

Variegata .......... Double-striped Camellia ................. ${ }^{0}$

Welbankii............ Captain Welbank's Camellia ................ 27 


\section{ENGLISH VARIETIES OF CAMELLIA JAPONICA.}

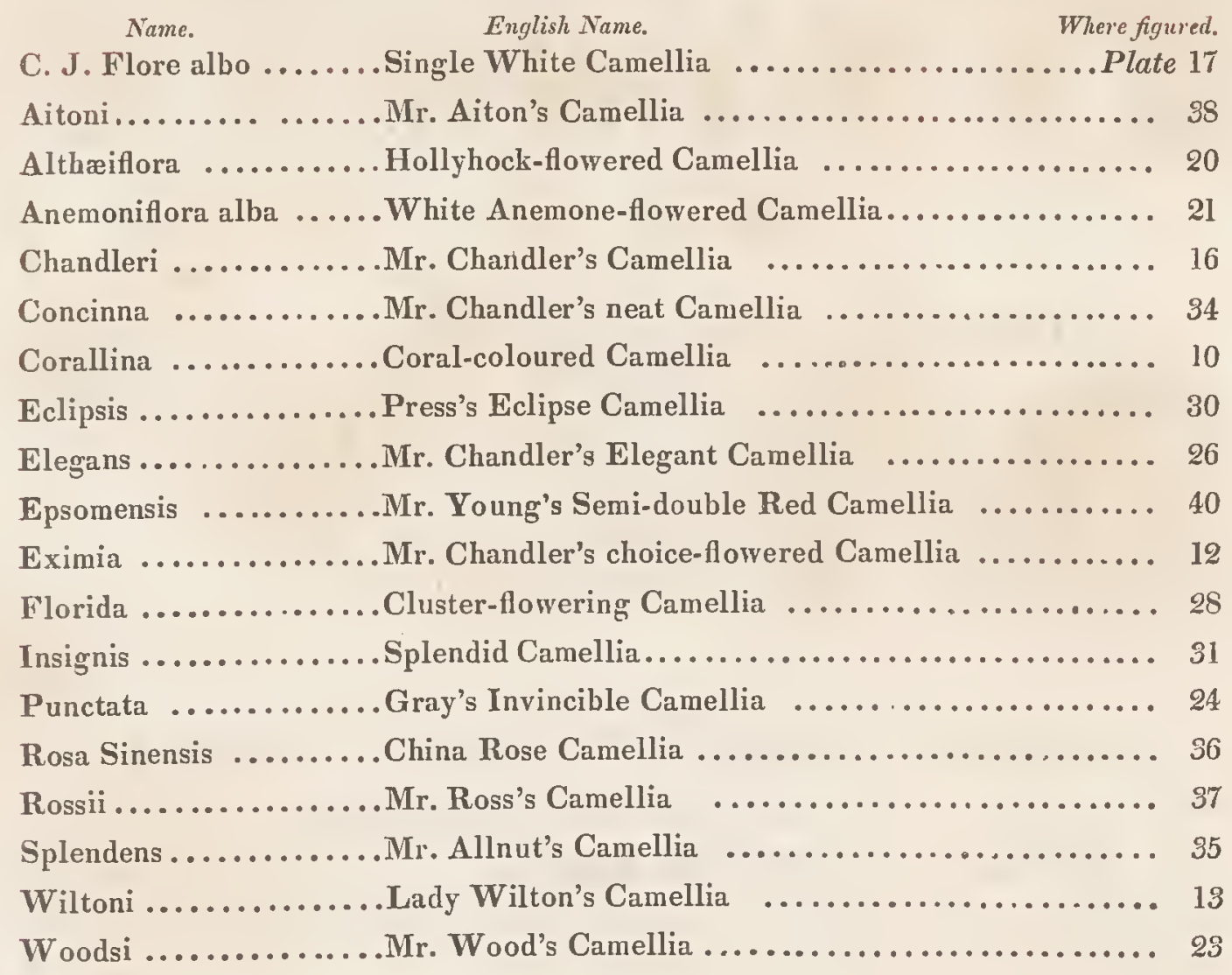

Directions for the Propagation and Treatment of Camellias, \&c...........page 41

* The Binder is requested to transpose the Plates No. 10, and 11. 


\section{INTRODUCTION.}

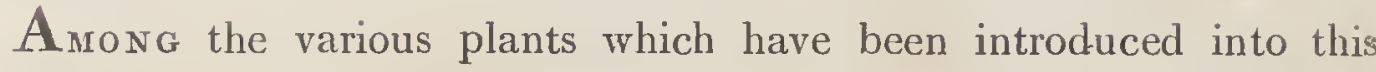
country, there are few, perhaps, more interesting, or more highly ornamental, than those which constitute the natural order Camellieæ. The whole of them, so far as we know at present, are indigenous to China, the islands of Japan, and the East Indies. In these countries they are held in great estimation; so much so, that their culture is regarded as an object of the utmost importance; particularly the genus Thea: the leaves of which, after undergoing a certain process, is the well-known Tea, which constitutes one of the chief articles of our commerce with the East, and the source from which a considerable portion of our national revenue is derived. This, of itself, is sufficient to recommend the Theas to the care and attention of every cultivator; whilst the Camellias, on the other hand, will always be esteemed for their beauty, especially the varieties of the Camellia Japonica, which are universally admired, and form, during the winter and early spring months, the most attractive ornament of the greenhouse and conservatory.

The order consists of only two genera, Thea and Camellia, which, from their great affinity to one another, has occasioned much diversity of opinion among botanical writers respecting them. By some, the Theas have been referred to Camellia; while others, with more propriety, regard them as forming a genus closely allied to, but differing 
viii

INTRODUCTION.

from Camellia, in several points of sufficient importance to justify their being separated. Linnæus not only considered them as two distinct genera, but as belonging to different classes, under which they will be found arranged in the first and second editions of his Species Plantarum ; the Theas, in Polyandria Monogynia; and the Camellias, in Monadelphia Polyandria. In the Prælectiones in Ordines Naturales, $\uparrow$ they are brought togetlier, and form part of the natural order Columniferæ; and it has 'been subsequently remarked by Sir James Edward Smith, in Rees' Cyclopedia (article, Thea), that they ought to stand next to one another in the artificial, as well as in the natural system.

Willdenow followed the arrangement of Linnæus, which was also adopted in the first and second editions of the Hortus Kewensis, and more recently by Professor Sprengel, in his Systema Vegetabilium. Mr. Ker and Dr. Sims have recorded their opinion in the Botanical Magazine, folio 998, that the two genera ouglit to be united; or, if they are to be kept separate, that they slould be placed in the same class. Professor Lindley, who has had the best opportunities of examining the genera, doubts the existence of any decisive limits by which Camellia is to be distinguished from Thea. In the Botanical Register, folio 1078, he has, however, given brief characters of the species, with large flowers, which he considers strictly referable to the former genus, namely, Camellia Japonica, C. Reticulata, and the plant known in the gardens as the Double Purple Sasanqua, which he has named C.Maliflora; while the other species, with small flowers, he would refer to Thea. This arrangement, although emanating from such an authority, appears to us objectionable, and for this reason:

* Species Plantarum, first edit. p. 515 and 698; second edit. p. 734 and 982.

+ Prælectiones in Ord. Nat. p. 451, \&c. 
because the plants, though possessing many of the characters common to Thea, will be found, on examination, to want those which are most essential in the distinguishing of that genus from Camellia.

The same uncertainty seems to have attended their arrangement in the natural system, as in the artificial. We have before stated that they form part of the natural order Columniferce of Linnæus. By Jussieu, they are placed in Aurantice; ${ }^{*}$ and by Ventenat, in Ebenacea. $\uparrow$ They are the Theacea $\neq$ of M. Mirbel, and the Camellieç of M. Decandolle. In this order they have been arranged by Mr. Don, in his Prodromus Floræ Nepalensis, p. 224, combined with Ternströmiacece, a tribe of plants which, in the structure of their flowers, as well as in their general habit and appearance, very much resemble those under consideration. 'The most essential difference between them, according to M. Decandolle, is in the seeds of the latter being without albumen. We shall here give the characters assigned to the order Camelliex, by that distinguished botanist, in his Prodromus, vol. i. p. 529.

\section{CAMELLIEA.}

CALYX. Sepals 5, 7, in æstivation imbricated, the inner often larger than the others, somewhat concave, coriaceous, deciduous. Petals 5, 6,9, (sometimes but not always) equal in number to thc sepals, alternate with them, and often cohéring at the base. Stamens, several. Filaments, filiform at the very base, monadelphous or polydelphous. Anther ellipsoid or round versatile. Ovary 1, ovate roundish. Styles 3, 6, filiform, more or less united. Capsules (see plate 1.) 3 celled, 3 valved,

* J uss. Genera, 262.

+ Ventenat, ii. 447.

† Bull. Phil. Decenbre, 1813.

Dec. Theor. Elem. ed. 1, Fevrier, 1813. 
splitting by the abortion of many of the ovules, 3 seeded, (the valves by an accidental alteration of dehiscence, ) either bearing the dissepiments in the middle, or forming them by the inflexion of their edges. Seeds fixed to the inner edge of the dissepiments, large, thick, and few. Albumen, none. Embryo, with large thick cotyledons, replete with oil, plano-convex, and, as it were, jointed at the base. Radicle, very short, obtuse opposite the hilum, drawn inwards, with a hardly conspicuous ascending plumule.

From the above definition, the plants which belong to the natural order Camelliea may be readily determined; we will therefore now proceed to the description of the genera which compose it. The first we shall notice is the genus CAMELLia, named in honour of George Joseph Kamel, a jesuit, whose name has been latinized into Camellus. He is author of Syllabus Stirpium in insula Luzone Philippinarum, annexed to the third volume of Ray's Historia Plantarum. The characters by which the genus is distinguished are as follow:

\section{CAMELLIA.}

Essential character.-Flowers, axillary sessile. Calyx inferior, of 7,8 , or more deciduous imbricated scales, the inner ones the largest. Petals, 5, 9. Styles united nearly their whole length. Capsule furrowed, having as many cells as furrows, and one or two seeds in each.

Generic character.-Calyx inferior, of many imbricated, deciduous, roundish-concave, downy scales. Petals, 5, 6, or 9, large, inversely egg-shaped, united and imbricated at the base, which is thick and fleshy. Stamens numerous, connected together for about one third their length, and rising erect in a sort of eylindrical cup or column; filiform, and nearly the same length as the petals. Anthers roundish, two-lobed. Ovary superior, roundish furrowed, pubescent. Styles 
united generally near their whole length, which is equal to that of the stamens; splitting at the point into 3, 5, acute stigmas. Capsules, nearly the size of a pigeon's egg, woody, furrowed, top-shaped, having as many cells as furrows, separated by slight partitions. Seeds, the size of a small nut.

The number of species hitherto introduced, which we consider referable to this genus, is six: viz. C. Japonica, C. Kissi, C. Malifiora, C. Oleifera, C. Reticulata, C. Sasanqua. In addition to these we may notice three others, which have been described as belonging to $\mathrm{Ca}$ mellia. The first is the C. Axillaris of Dr. Sims, figured under this name in the Botanical Magazine, t. 2047; the Botanical Register, t. 349; and in Loddiges's Botanical Cabinet, t. 675. It has since been ascertained not to be a Camellia, but to belong to a different genus. In the Systema Vegetabilium of Sprengel, vol. iii. 126, it is described as Gordonia Anomala; and in Sweet's Hortus Britannicus it is called Polyspora Axillaris. The latter name has been adopted in Loudon's Hortus Britannicus, where it is referred to the natural order Ternströmiacex.

The second species is the Camellia Drupifera of Loureiro, (Flora Cochinchinensis, vol. ii. 499,) which is questioned by M. Decandolle, although inserted in his Prodromus, vol. i. 529. By Sprengel it is described under the name of Mesua Bracteata. Judging from Loureiro's description, for we have not had an opportunity of seeing specimens of it, we think it a very doubtful species, and apparently distinct from Camellia. The plant has not yet been imported.

The third species is the Camellia Euryoides of the Botanical Register, t. 983, and of Loddiges's Botanical Cabinet, t. 1493. This plant is the connecting link between the two genera, Thea and Camellia, as it possesses several characters peculiar to both, but, in our opinion, agrees in more points with the former, than with the latter. It is a low 
bushy shrub, and remarkable on account of its being one of the plants upon which the Chinese graft their varieties of the Camellia Japonica.

Of the six species above enumerated, five will be found illustrated and described in this volume. The first of these, the Camellia Japonica, which we shall presently notice, must be considered as the type of the genus. The one omitted is the Camellia Kissi, of Dr. Wallich, which is but little known in our gardens, having only been introduced a few years since, and, as far as we have been able to learn, has not yet flowered in this country. An elaborate account of it is given in the Asiatic Researches, vol. xiii. p. 428.

We need scarcely add that the whole of the figures, both of the species of Camellia, and the varieties of Camellia Japonica, with only two or three exceptions, have been made from plants in the splendid collection of Messrs. Chandler, Vauxhall. 


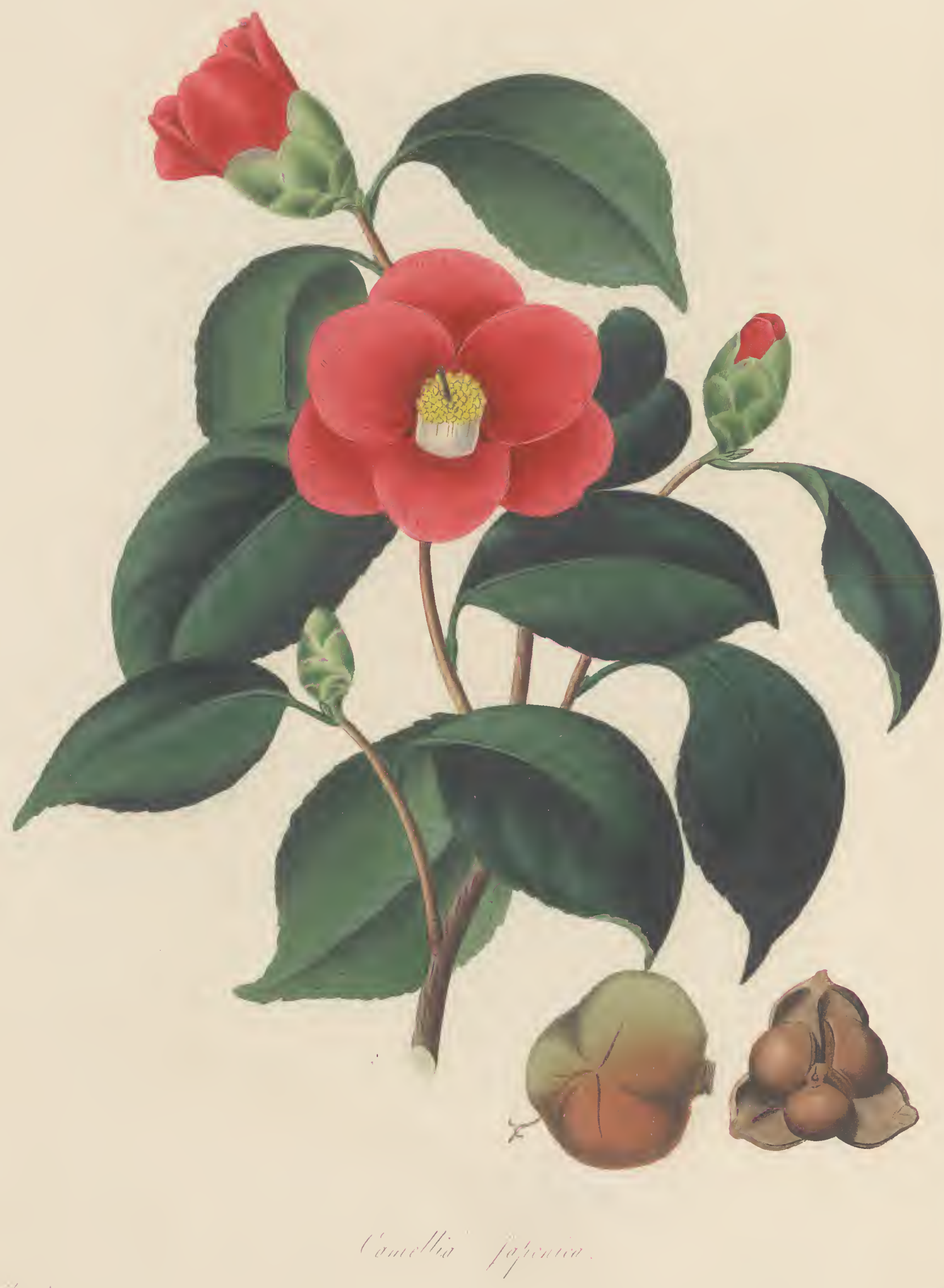






\title{
CAMELLIA JAPONICA,
}

\author{
Single Red Camellia.
}

Camellia Japonica, foliis ovatis acuminatis serratis nitidis convexis, ramulis petiolisque glabris. Lindley.

Camellia Japonica, Linn. Syst. Veg. Ed. 14. 632. Thunberg's Fl. Japon. p. 273. Willdenow's Sp. Plant. 3. 842. Schneevooght's Icones, 7. Cavanilles Dissert. 6. 305, t. 160, f. 1. Jacquin's Ic. rar. 3. 553. Duhamel's Traité des Arbres, \&c. Ed.2. 243, t. 71. Bot. Magazine, t. 42. Hort. Kew. Ed. 2. 4. p. 235. Curtis's Monograph, p. 1. Decandolle's Prodromus, 1. p. 529.

Thea Chinensis pimentæ jamaicensis folio, flore roseo. Petiver's Gaz. t. 33, f.4.

Tsubaki Kæmpfer. Amœn. 850, t. 851.

Rosa Chinensis, Edwards's Birds, 2. p. 67, f. 67.

THE single red Camellia is stated, in the Hortus Kewensis, to have been cultivated before 1739, by Robert James Lord Petre, and is the first of the genus that was introduced into this country. Although it was figured and described by Petiver, in his Gazophylacium, in 1702, under the name of Thea Chinensis, and by Kæmpfer, in 1712, under that of Tsubaki, yet it would appear to have been rare in our gardens in the time of Miller, as it is not noticed in the eighth edition of his Dictionary, published in 1768. For many years it was very scarce, and as it bore a high price, was generally treated as a stove plant; but when it became more plentiful, it was found to succeed equally well in a much lower temperature, and is now considered sufficiently hardy to endure the common winters of this climate, with only a slight protection in very severe weather; as is the case with many other plants, which have been introduced from the same interesting country.

It is of free growth, and, in China, is said to attain the height of one of our Cherry-trees. The stem is erect and branching, of a pale brown colour. The branches are round, clothed with numerous alternate, thick, ovate-acuminate, dark shining green leaves, each about three inches long, and two inches broad, tapering towards the base and point, and having their edges sharply serrated, and waved. The midrib is strong and prominent on both sides of the leaf, but is most conspicuous on the lower side, which is somewhat veiny, and of a pale shining green, covered with numerous small dots. The foot-stalks are about 
half an inch long, quite smooth, and slightly channelled on the upper side; otherwise they are round, and of the same yellowish-green colour as the midrib.

Flower buds oval, and much pointed, covered with seven or eight roundish-cordate, pale green, pubescent scales, which generally become brown, and drop when the flower is fully expanded.

The flowers are freely produced, and open in the winter and early spring months, with those of the double Camellias. They are from one and a half to two inches in expansion, and are composed of five, sometimes seven, roundish or roundish-cordate petals, each of which is about an inch in diameter, imbricated and connected together at the base, but opening so as to have an upright bell-shaped appearance. They are of a bright rose or red colour, and veined with darker coloured lines. In the centre of the flower rise the stamina, which are filiform, thick and fleshy at their base, and united to the petals as well as to one another, thereby forming a kind of cylindrical cup, of a yellowishwhite colour. The anthers are large, and of a deep yellow. The styles are generally three, closely connected together, excepting at the point, which is of a greenish colour. They are about the same length as the stamina. The seeds frequently come to maturity, and are contained in a woody pear-shaped capsule, slightly furrowed, having as many divisions as there are styles or furrows, with one or two perfect seeds in each, and several small imperfect ones; the former resemble a small brown nut, but are somewhat angular, and indented on the side next to the axis.

Fron this species has originated nearly the whole of the double varieties, which it is our object in this Work to illustrate and describe. Being of free growth, and easily increased by cuttings, it is of great value to the cultivator, as it affords an excellent stock whereon to inarch or graft the other Camellias, for which purpose it is extensively cultivated in the neighbourhood of London. 



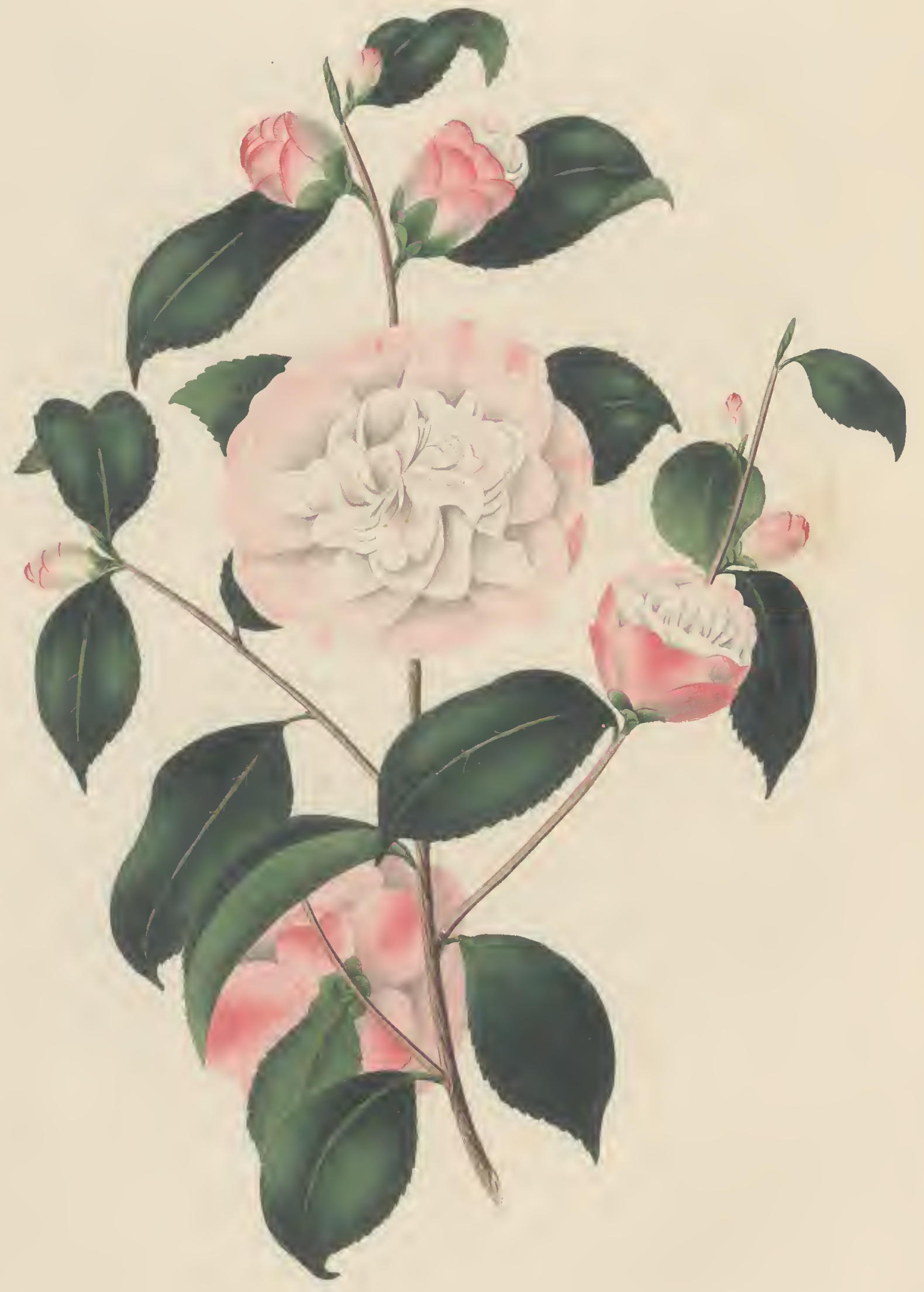

Candlin. Mteliflem 


2.

\title{
CAMELLIA MALIFLORA,
}

\author{
Apple-Blossomed Camellia.
}

Camellia Maliflora, foliis obovatis acuminatis nitidis convexis, ramulis petiolisque pubescentibus, ovario glabro. Lindley.

Camellia Sasanqua, $\beta . \quad$ Palmer's Double Sasanqua. Botanical Magazine, t. 2080.

Camellia Sasanqua, $\beta$. stricta: fl. pl. carneo. Mrs. Palmer's Camellia. Botanical Register, t. 547.

Camellia Sasanqua pleno-carneo. Loddiges's Botanical Cabinet, t. 1134.

THIS plant, although figured and described in the works above referred to, as being a variety of Camellia Sasanqua, is unquestionably very distinct from that species. In growth it is erect and slender, and forms a compact bushy shrub, which in the spring months is covered with a multitude of delicate purplish-red flowers. The branches are round, twiggy, erect, densely clothed with pubescence, and of a dark brown colour.

The leaves are obovate, seldom more than two inches long, and one inch broad in the widest part, much pointed and recurved, with numerous small sharp serratures. They are of a thin substance, compared with those of the Camellia Sasanqua, or Camellia Japonica: to the latter perhaps they have the nearest resemblance, and like them are of a dark shining green; but they have a pale-coloured villous midrib, and short round villous foot-stalks.

The flower buds are oval, and blunt at the point, with comparatively large roundish-cordate, pubescent, brownish-green scales.

The flowers vary from one and a half to two inches in diameter, and are remarkably handsome, being very regular in their formation, and of a pale purplish-red colour. The outer petals expand quite flat, some of them indeed are often a little reflexed, but so arranged as to give a nice even circumference to the whole flower; they are each about three-fourths of an inch broad, nearly round, or but slightly divided at their extremity, and of a darker colour than the interior petals, which are very pale, excepting at their base, where they have the same purplish tinge as the exterior ones. In general, the centre petals rise upright, and a few of them a good deal resemble stamens, 
from being yellowish at the tip. They are short, numerous, and irregularly shaped, often undulated and deeply divided, but all of nearly equal height, and disposed in such a manner as to give to the flower the appearance of a small double purplish-coloured Rose. In some Howers, where the petals are not very numerous in the centre, a few parcels of imperfect stamina may be observed; generally, however, they are transformed into small narrow petals.

It was first brought to this country, in 1816, by Captain Richard Rawes, who presented the original plant to his relation, Thomas Carey Palmer, Esq. of Bromley, in Kent, in whose choice collection it flowered in 1818, and was afterwards published in the Botanical Magazine, as a variety of Camellia Sasanqua; hence it has been cultivated, and is usually known by the name of the Sasanqua Rosea, or Palmer's Double Sasanqua Camellia: but from that species it has been lately separated by Mr. Lindley, in the Botanical Register, f. 1078, who has applied to it the very appropriate name we have here adopted.

It is propagated freely by inarching on the single red, and requires a little more warmth to grow it to perfection than the varieties of Camellia Japonica. 



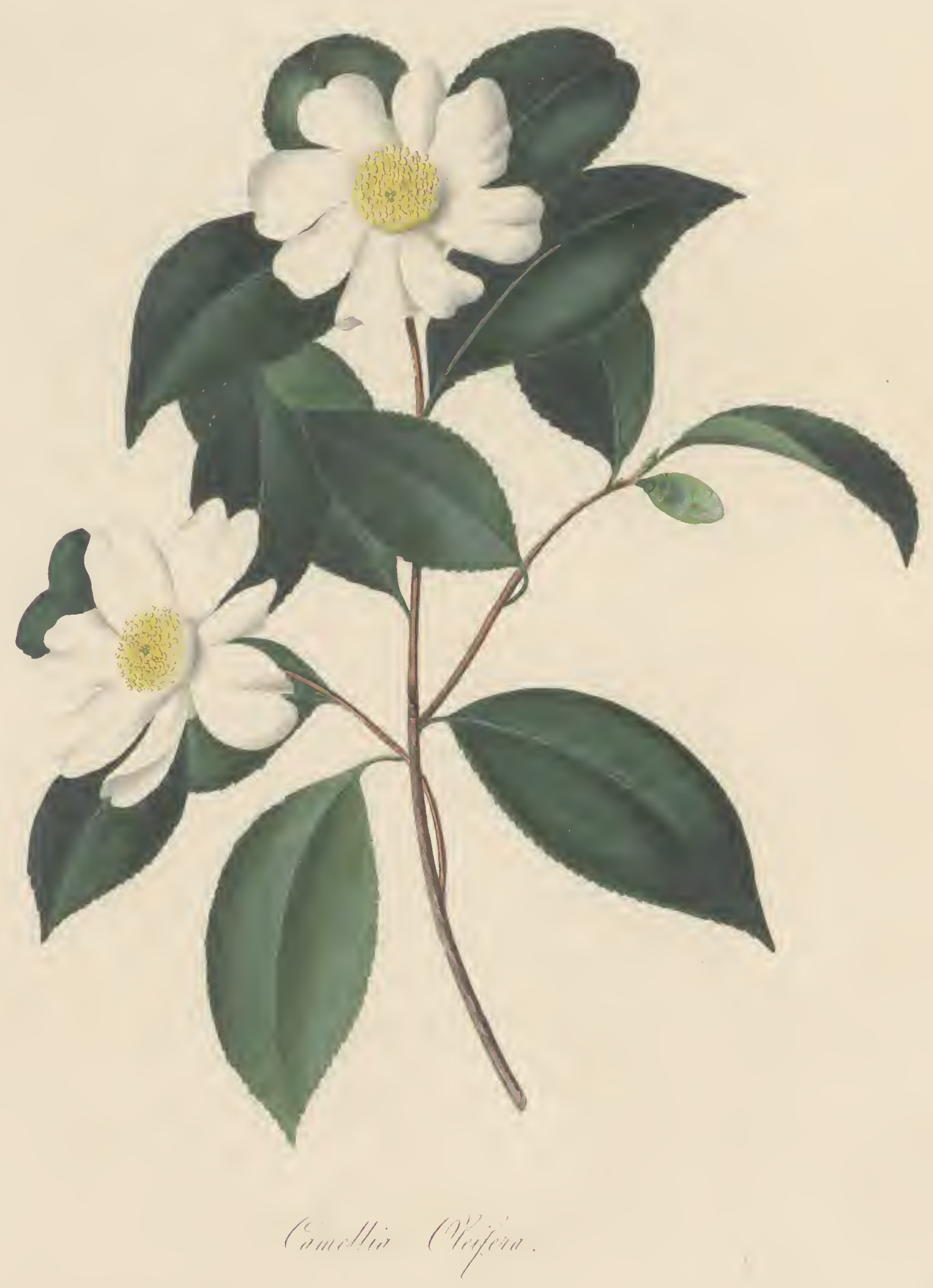




3.

\section{CAMELLIA OLEIFERA.}

\section{Oil-seed Camellia.}

Camellia Oleifera, foliis ellipticis utrinque acutis argutè serratis subtus subaveniis, petalis bilobis, sepalis deciduis. Lindley, in Botanical Register, f. 942. Camellia Oleifera, Abel's Journey in China, p. 174. App. 363.

Camellia Oleifera, Loddiges's Botanical Cabinet, t. 1065.

THIS species has been overlooked by M. Decandolle, in his Prodromus. It is the famous Oil-seed Tree of the Chinese, who cultivate it, according to Dr. Abel, in large plantations, for the sake of the excellent oil, which they obtain from it in abundance by a very easy process, and use for various domestic purposes. It is called by them Tcha-Yeoa, which may be interpreted, the "Oil-bearing Tea Plant:" a very expressive name, as the plant in appearance closely resembles the Tea. This author has given a good figure of it, in the interesting narrative of his Journey in China; and states that it naturally grows in a red sort of soil, and will thrive where scarcely any other plants will succeed. It was sometimes found by him of the magnitude of a moderately-sized Cherry-tree, and always that of a large shrub from six to eight feet in height, and bearing a profusion of single white blossoms. This circumstance gave an interesting and novel character to the places which it covered. They often looked, in the distance, as if lightly clothed with snow; but, on a nearer approach, exhibited one immense garden. It is said to have been first brought to this country by Lord Macartney's embassy, but was afterwards lost, until 1820, when Captain Nesbitt, of the Honorable East India Company's ship Essex, imported plants of it for the Horticultural Society, by whom it has been distributed.

It has some distant resemblance to the Camellia Sasanqua, but is readily distinguished from that species, being of a much more robust habit, and larger in every respect. The branches are round, somewhat. pendulous, of a dark brown colour, and when in a young state, thickly clothed with pubescence.

The leaves are thick, smooth, veiny, and flat, about four inches long, and two inches broad, elliptic, tapering to both ends, but sharpest at the point, with moderately large sharp serratures, which become 
blunt and indistinct towards the base of the leaf. They are of a dull dark green above, and of a pale shining green beneath, covered with numerous small dots. The midrib is slightly villous on the upper side, and of a pale green colour, together with the foot-stalks, which are short, channelled above, and very pubescent.

The flower buds are larger than those of the Camellia Sasanqua, nearly oval, and covered with upwards of seven roundish, concave, pubescent, pale yellowish-green scales, which become brown before they drop.

The flowers usually open in November, and are not very conspicuous in comparison with those of the Camellia Japonica. They measure, when fully expanded, rather more than two inches in diameter, and are composed of five, sometimes six, or even a greater number of roundish-oblong white petals, slightly tinged with pale yellow at their base. On first opening, the flowers are cupped, but afterwards the petals spread almost flat, and ultimately become much twisted and recurved: each of them is thick and fleshy at the base, from which they gradually enlarge, and become thinner towards the extremity, which is about half an inch in breadth, in some flowers deeply divided, and in others only partially so. The stamina are short and numerous, and rise in a close cylindrical cup round the styles, which are pale green, usually three in number, united almost their whole length, but divided at the top, and a little recurved. The anthers are large, and of a deep yellow colour. The fiuit has not yet been known to come to maturity in this country.

It is very easily increased by grafting on the single red Camellia, and will thrive well if placed in an airy situation in the green-house or conservatory. When in a growing state, the plants require a plentiful supply of water.

The accompanying figure was made in October last, from a specimen which was kindly communicated to us by Mr. Mackay, of the Clapton Nursery. 



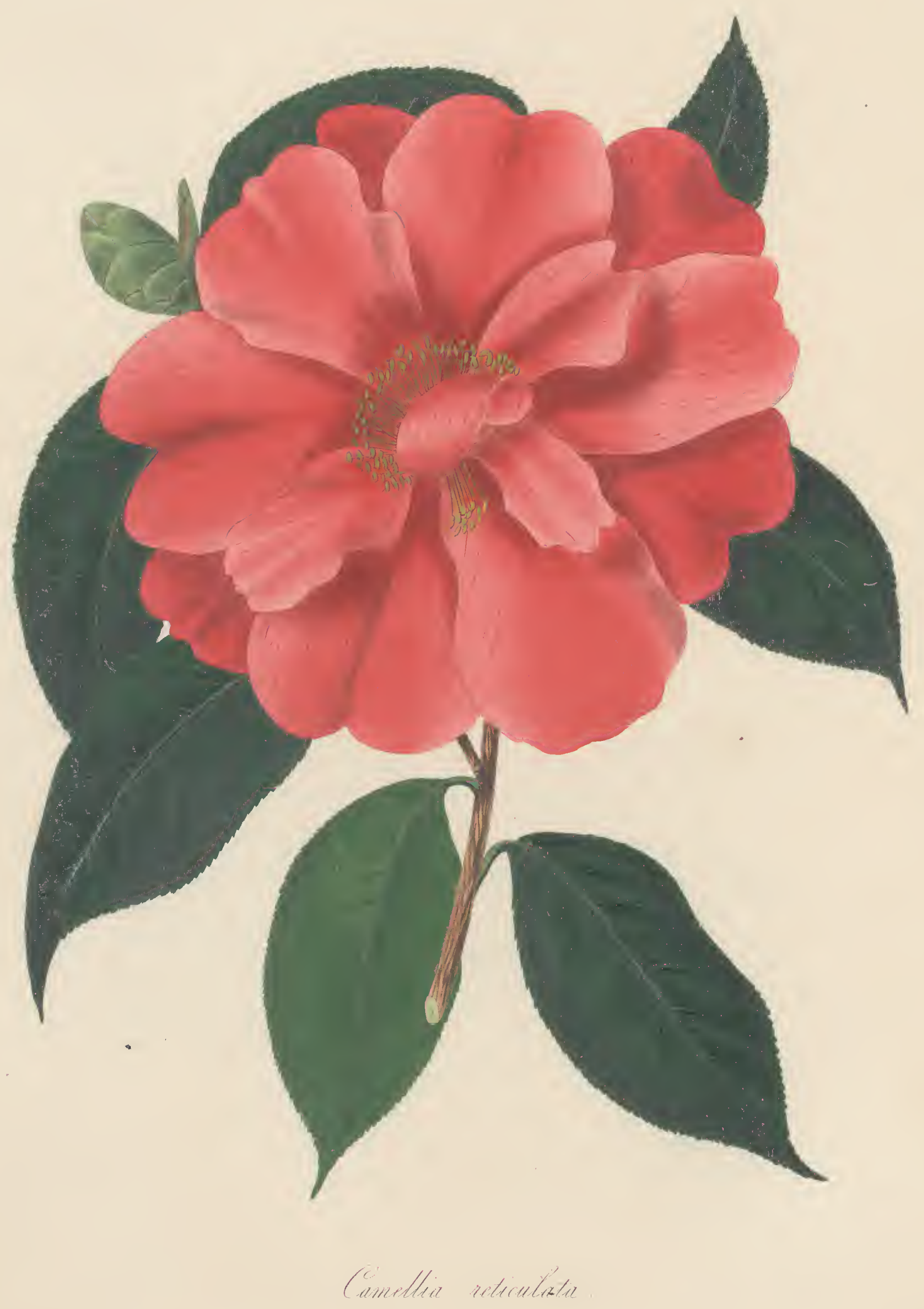

1. Cheneltes del. 



\section{CAMELLIA RETICULATA.}

Captain Rawes's Camellia.

Camellia Reticulata, foliis oblongis acuminatis serratis reticulatis planis, ramulis petiolisque glabris, ovario sericeo. Lindley.

Camellia Reticulata. Botanical Register, t. 1078. Botanical Magazine, t. 2784.

THE merit of first introducing this fine species is due to Captain Richard Rawes, of the Honorable East India Company's service, who brought home a plant of it, in 1820, for his friend, Thomas Carey Palmer, Esq., at the same time with another great ornament of our gardens, the Primula Sinensis.

It is of a strong, robust habit, and very distinct, from any of the other Camellias. The branches are round, smooth, and erect, sparingly furnished with oblong, sharp-pointed, thick, flat, strongly reticulated, dull green leaves, usually three inches and a half long, and upwards of an inch broad, with a strong pale green midrib, and numerous small sharp serratures. The foot-stalks are about a quarter of an inch long, brownish-green, and a little channelled on the upper side.

The flower buds are very large, of an oval form, somewhat pointed, and covered with six or more proportionably large, roundish, concave, pale green, pubescent scales; the inner ones often coloured at the edges like the petals.

The flowers are remarkably handsome, and have a great resemblance, both in form and colour, to those of the Pconia Moutan Rosea. They usually appear during the months of February, March, and April, and measure, when expanded, no less than five inches and a half in diameter. The petals are about seventeen or twenty in number, of a clear purplish-red colour, much undulated, and irregularly and loosely arranged; each of them is two inches and a half long, and rather more than an inch broad at the extremity, sometimes divided, but generally entire, and strongly marked with dark-coloured veins. In the centre of the flower, there are often a few petals very different in form, and rather paler than the others, which rise upright, and divide the stamina into separate parcels; they are for the most part narrow, deeply cut, 
and not unfrequently a little striped at their base, and twisted. The stamina are about half the length of the petals, ranged in several rows, the inner ones rather separate from the others. Styles united, excepting at the point, often four, but most commonly three in number, and about the same length as the stamina. Ovarium roundish, silky, four celled, with several distichous ovules.

This species has been described by Mr. Lindley, in the Botanical Register, where an excellent figure will be found of it, as well as another in the Botanical Magazine. It is by far the most splendid of the genus that has yet been introduced. We first saw it in flower in Mr. Palmer's collection at Bromley, in the spring of 1826 , and to that gentleman we are indebted for the opportunity then afforded us of describing it. We have since observed it in the collection of the Horticultural Society, by whom plants of it were imported in 1824, by their Collector, Mr. John Damper Parks; from one of which, that flowered in 1829, the accompanying figure was made, with permission of the Council.

It seems to be more difficult to propagate than any of the other Camellias, but we have no doubt that, in the course of a few years, the exertions and liberality of the Horticultural Society, and of Mr. Palmer, will make it as common as it really deserves to be. The best way of increasing it is by inarching on the single red Camellia; for, although it will succeed by being budded or grafted in the usual manner, yet the plants that are obtained by these means, are long in making any progress, compared with those obtained by inarching. We are of opinion, that when it becomes so plentiful as to admit of a trial being made, it will be found to be hardier than the Camellia Japonica, and at no distant period, perhaps, may ornament our shrubberies. 



$$
\text { g. }
$$




5.

\title{
CAMELLIA SASANQUA,
}

Lady Banks's Camellia.

\begin{abstract}
Camellia Sasanqua, ramis virgatis capsulâque villosis; foliis junioribus ellipticolanceolatis, serratis; petalis obovatis vel obcordatis. Bot. Reg. fol. 12.

Camellia Sasanqua. Thunberg's Flora Japon. 273. t. 30. Cavanilles' Diss. 6. 306, t. 160, f. 2. Willd. Sp. Plant. 3. 842. Hortus Kewensis, 2 Ed. 4. 235. Poiret Suppl. Encyc. de Lamarck, 2. 48. Curtis's Monograph, pl. 1. Decandolle's Prodr. 1. 529. Loddiges's Bot. Cab. t. 1275.

Sasanqua. Kæmpfer's Amœn. Exot. 853.

Cha-Whaw of the Chinese. Staunton in Macartney's Embassy, vol.2. p. 467, with a good figure.
\end{abstract}

THIS plant is recorded, in the last edition of the Hortus Kewensis, to have been introduced in 1811, by the Honorable Court of Directors of the East India Company, in the Cuffnels, Captain Wellbank. Its specific name (Sasanqua) is that by which it is known in Japan, where, as well as in China, it is extensively cultivated, and considered of equal importance with the Camellia Oleifera, which we have already figured and described.

It is of a loose, straggling habit, but if the principal stem is supported when young, it will attain the height of six or eight feet. The branches are mostly pendulous, round, and twiggy, of a deep brown colour, deciduously villous, and weak.

The leaves are elliptic-lanceolate, thick, smooth and flat, upwards of two inches long, and one inch broad, with small roundish serratures; they are of a dark shining green, and have a prominent pale green, villous midrib. The footstalks are about a quarter of an inch long, slightly villous and channelled above; rounded beneath, nearly smooth, and of a pale green colour.

The flower buds are sometimes produced singly from the axils of the leaves, but generally they are terminal, solitary, and sessile. They vary in size, and are smaller than those of the Camellia Oleifera, or Camellia Maliflora; of a roundish oval form, covered with numerous roundish concave, imbricated, pale green, silky scales.

The flowers, which are white, open in November and December, 
and are each about one inch and a half, or two inches in diameter, very much resembling those of the Tea Tree. They are pretty freely produced, and are composed of from five to ten, or even more, oval, concave, sometimes obcordate, slightly incurved petals, ranged in one or two rows, according as the flower happens to be single, or semi-double. In the former case, the petals are nearly half an inch in breadth, and expand almost flat; but in the latter they are a little twisted, and seldom exceed a quarter of an inch in breadth at their extremity. The filaments are filiform, rather shorter than the petals, generally spreading, though sometimes they rise in a close cylindrical sort of cup, and surround the styles, which are three in number, united as in the other species of Camellia, and of a pale greenish yellow colour, with simple stigmas. The anthers are large, two lobed, deep yellow.

Among the Chinese drawings in the Library of the Horticultural Society, there are three representations of this Camellia; one with the flowers perfectly double, like those of the White Rosa Banksice, and two with the flowers semi-double. A plant of the former variety was imported for the Society, by Captain Drummond, in 1823, and flowered in the Garden at Chiswick, in December, 1826. It has since been published in the Botanical Register, folio 1091. As it differs in no respect from the plant we have just described, excepting in the flowers having a greater number of petals, we think it unnecessary to give a figure of it.

The soil, in which the Camellia Sasanqua is said to be cultivated with success, in China, consists of little more than fragments of loose stones, crumbled into a sort of coarse earth, by the joint action of the sun and rain. In this country, we have remarked that it succeeds best, when grown in a moderately strong, rich, sandy soil ; and is readily increased by inarching, or grafting on the single red Camellia. 



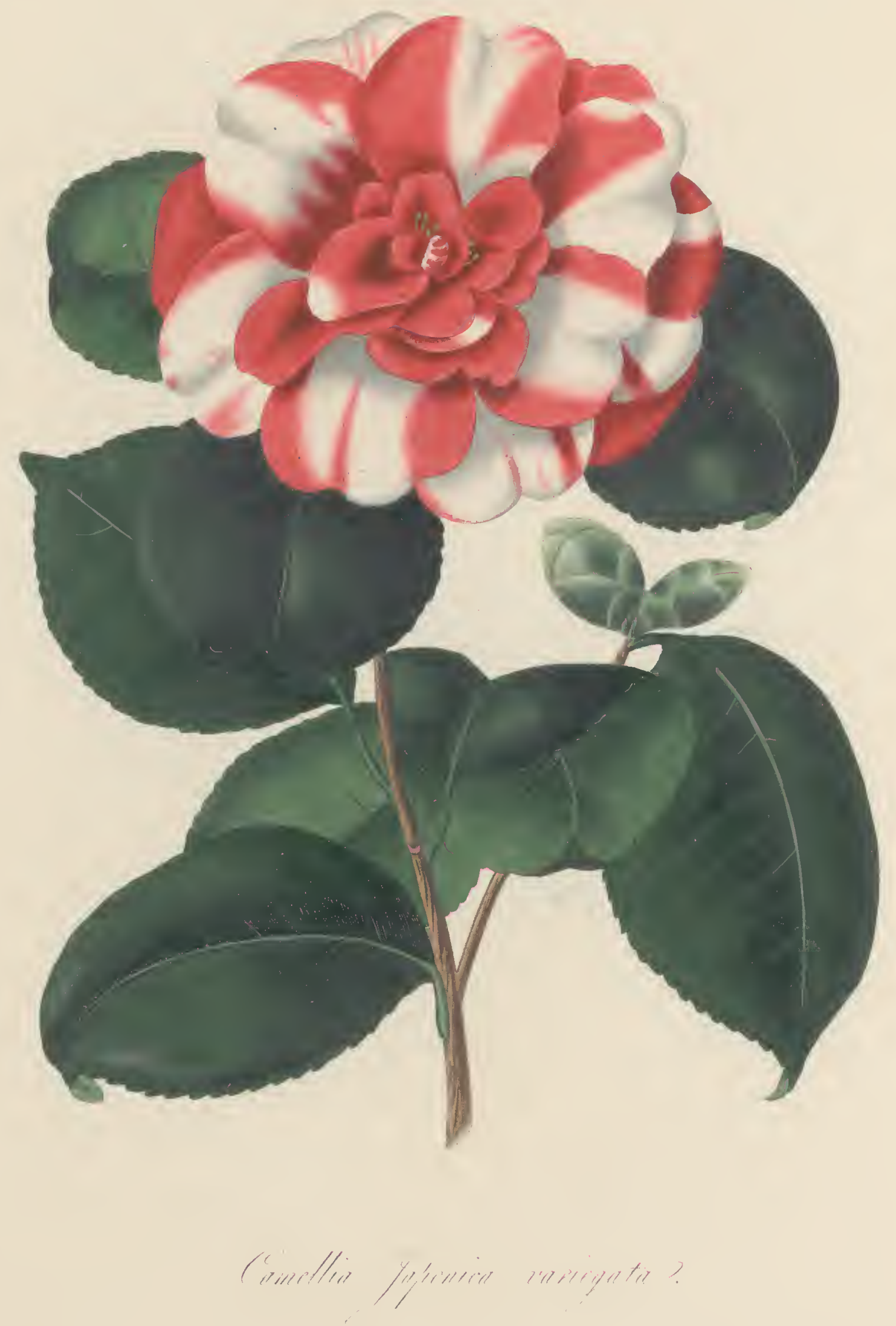




6.

\title{
CAMELLIA JAPONICA VARIEGATA,
}

\author{
Double-Striped Camellia.
}

Camellia Japonica. Var. flore pleno variegato. Botanist's Repository, pl. 91. Camellia Japonica Varieguta, Loddiges's Bot. Cab. t. 329.

Double-Striped Camellia, Curtis's Monograph, pl. 2.

THE splendid variety here represented, is one of the first of the double Camellias that was brought from China: a plant of it having been imported, in 1792, by Captain Connor, of the Carnatic, East Indiaman, for the late John Slater, Esq. of the India House. It is usually among the earliest in coming into blossom, and is of a robuist habit, with comparatively strong, dark-coloured spreading branches.

The leaves are three and a half inches long, and two inches broad, roundish ovate, somewhat convex, with moderately large serratures, and a bluntish recurved point; they are of a dark shining green, and have a strong prominent pale-coloured midrib. The footstalks are short and thick, a little flattened on the upper side, otherwise round, and of a pale green colour.

Flower buds roundish oval, rather more than an inch long; scales large, and nearly round, pale green, densely clothed with pubescence.

The flowers are of a fine dark rose, or red colour, irregularly blotched with white; but in this respect they vary considerably, the autumnal or early flowers being always most elegantly variegated, whilst those which appear in the spring, are generally plain red. They are from three to four inches in expansion. The outer petals are each about an inch and a half in diameter, roundish cordate, thick and fleshy at the base, and broad and thin at the points and edges. They are at first nearly flat, and evenly disposed in several rows, laid over one above another; but after the flower has been some time open they become recurved. The centre petals are small and round, frequently arranged in tufts, with a few parcels of stamina, twisted and intermixed among them. Some flowers are particularly handsome, and as double as a Rose, without any stamina being perceptible; others, again, are of an irregular shape, and little more than semi-double, 
having the centre filled with stamina partly perfect, and partly transformed into small, narrow, often deeply divided petals. The parts of each of the petals which are red, are faintly marked with darker coloured veins, and when touched by cold, or as the flower begins to fade, the edges become slightly tinged with purple.

In some Collections, a variety is supposed to exist of this kind, with blotched or variegated leaves, as well as flowers; but this character is by no means a permanent one, and generally arises from the plant being in an unhealthy state, occasioned by bad soil, or improper treatment.

To flower this variety well, it is usual with some cultivators to place the plants in a warm part of the greenhouse, or even the stove, in spring, so as to forward their growth, and make their flowers open in the autumn. Where this is done, they are seen to far more advantage than where they are allowed to remain, to open at the same time with the other Camellias. We shall, however, return to this subject, and enter more fully upon it hereafter; as well as upon other points connected with the proper treatment, and the soil best adapted for the culture of this very ornamental tribe of plants. 



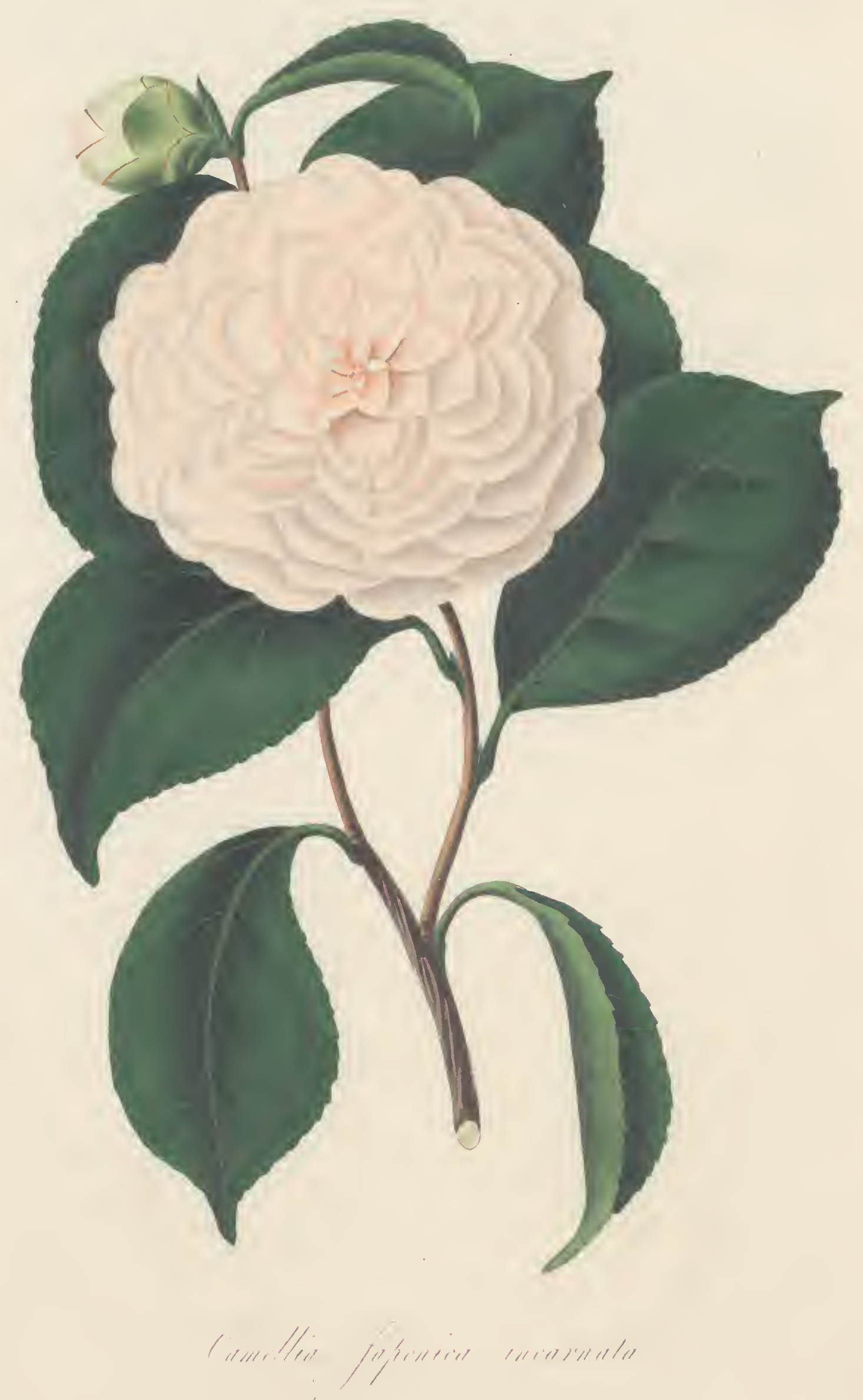



- 
7.

\title{
CAMELLIA JAPONICA INCARNATA.
}

\author{
Lady Hume's Blush Camellia.
}

Blush Camellia. Bot. Repository, 660. f. 1. Bot. Register, t. 112. Camellia Japonica Incarnata. Loddiges's Bot. Cabinet, t. 140. Buff, or Hume's Blush Camellia. Curtis's Monograph, pl. 5.

THE first plant of this fine variety was imported in 1806, for the late Lady Amelia Hume, of Wormleybury, in Hertfordshire; in honour of whom it received its name. In growth and foliage it has much of the character of the double white, and has been nearly as extensively cultivated, being found in almost every Collection.

The shoots are long and straggling, of a deep brown colour when young, but changing to a pale brown, as they grow old. The leaves are from three and a half, to four inches long, and about two inches broad in the widest part, which is nearest the point; recurved, and slightly undulated at the edges, with moderately large serratures, and numerous prominent veins, considerably paler than the general colour of the leaves, which is a rich shining green. The footstalks are about three quarters of an inch long, rounded on the lower side, and slightly flattened above.

Flower buds, often two together, of a roundish oval form, with broad roundish cordate, pale green, pubescent scales, which become brown at the edges, as the flower approaches expansion: and when it is fully expanded, are entirely of a yellowish brown colour, to which the pubescence gives a delicate silvery tinge.

The flowers are freely produced, and open very regularly; they are from three to three and a half inches in diameter, of a fine glowing flesh colour, becoming richer as they expand, and fading if too much exposed. The outer petals are each about an inch in diameter, nearly round, and frequently a good deal recurved. Towards the centre of the flower, which is pitted as in the double white, the petals gradually diminish in size, and are pointed. In general they are evenly arranged, and when the flower is very double, they are laid over one another, in such a manner as to give to it an hexangular appearance; a peculiarity 
which, as far as we have seen, is confined to the flowers of this variety alone.

The true hexangularis, or, at least, the sort known by that name to cultivators, and so beautifully portrayed in the Chinese paintings, which are sometimes brought to this country, is quite a distinct plant from this, and apparently nothing more than a variety of the myrtleleaved.

The figure in the Botanical Register, quoted above, represents it with the flower hexangular; the leaves, however, are not very characteristic of it, being too strongly serrated and pointed. The same may be said of the figure in the Botanist's Repository, although they both convey a pretty clear idea of the appearance of the flower. In the other works referred to, very correct representations will be found of it. 



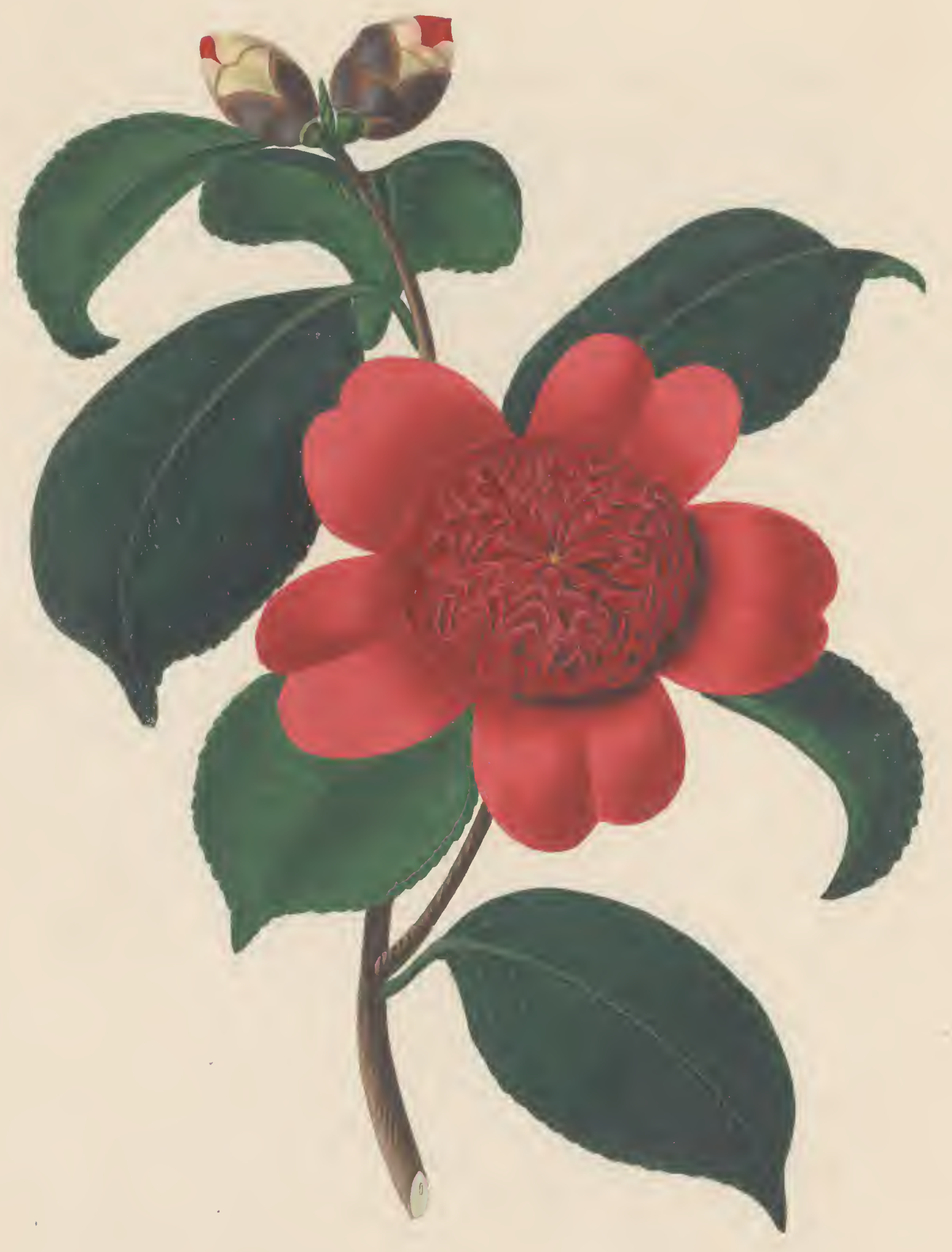

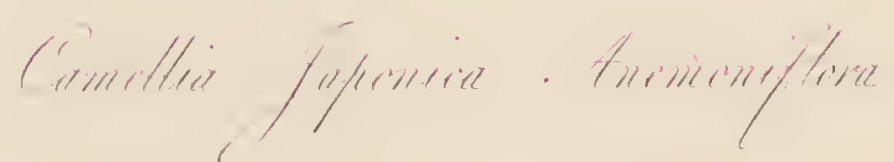


8.

\title{
CAMELLIA JAPONICA ANEMONIFLORA
}

\author{
Anemone Flowered, or Waratah Camellia.
}

Camellia Japonica Anemoniflora. Bot. Magazine, t. 1654. Lodd. Bot. Cab. t. 537. Anemone Flowered, or Waratah Camellia. Curtis's Mon. pl. 4 .

IN Curtis's Monograph this sort is stated to have been imported in 1812 , for the Royal Garden at Kew, but we have reason to believe that it was n the country several years before that time; in which we are conirmed by Messrs. Loddiges, who record its introduction to Kew to have been about the year 1806 .

It is very distinct from any of the other Chinese varieties, and is always readily distinguished by its flat, and comparatively narrow, pointed leaves, and long, slender footstalks. It is usually among the latest in coming into blossom, and does not produce its flowers so freely as some of the other red flowering kinds. In growth it is moderately strong and erect, the branches are of a dark brown colour, and sometimes a little striped.

The leaves are from four to four and a half inches long, and about two or two and a half inches broad, recurved at the points and edges, but otherwise quite flat, and of a very dark shining green colour, in which the veins are scarcely perceptible; the serratures are small and sharp pointed; the midrib is strong and prominent, particularly on the under side of the leaves, and of a pale green colour. The footstalks are an inch long, round and slender, somewhat curved, giving to the leaves a pendant position.

Flower buds oval, tapering towards the point, with roundish pointed, dark brown or chocolate-coloured scales, densely clothed with pubescence.

The flowers are remarkably shewy, and resemble a large double Anemone, from which circumstance the variety has received its name. They vary from about three to four inches in diameter, and are of a deep red colour. The outer petals expand quite flat, and are five or six in number, most commonly the former, surrounding a great many smaller petals, regularly disposed, and rising upright in the centre of the flower; 
each of them is roundish cordate, from one to one and a half inch in breadth, and slightly marked with veins, a little darker than the colour of the petal. Those in the centre of the flower are of a very peculiar form, being small and fleshy at the base, and broad and thin towards the point, with a very minute white tip; they are compactly ranged in rows, from the circumference to the centre, which is considerably elevated above the large outer petals, and are each incurved towards the styles, with their edges turned outwards. The styles are a little higher than any of the petals, and have large greenish stigmas, which are sometimes fertilized by a few of the stamens that may not be transformed into petals; but more frequently they are impregnated by cultivators with the pollen of other sorts, and from the seed obtained in this way, many of the finest double varieties, that are now cultivated in this country, have been raised.

The flowers of this, as well as of some of the other kinds, drop off whole, and will retain their freshness for a considerable time afterwards; so that if placed upon a bud, they appear still to be growing. tioned.

Good figures will be found of it in the several works above men- 



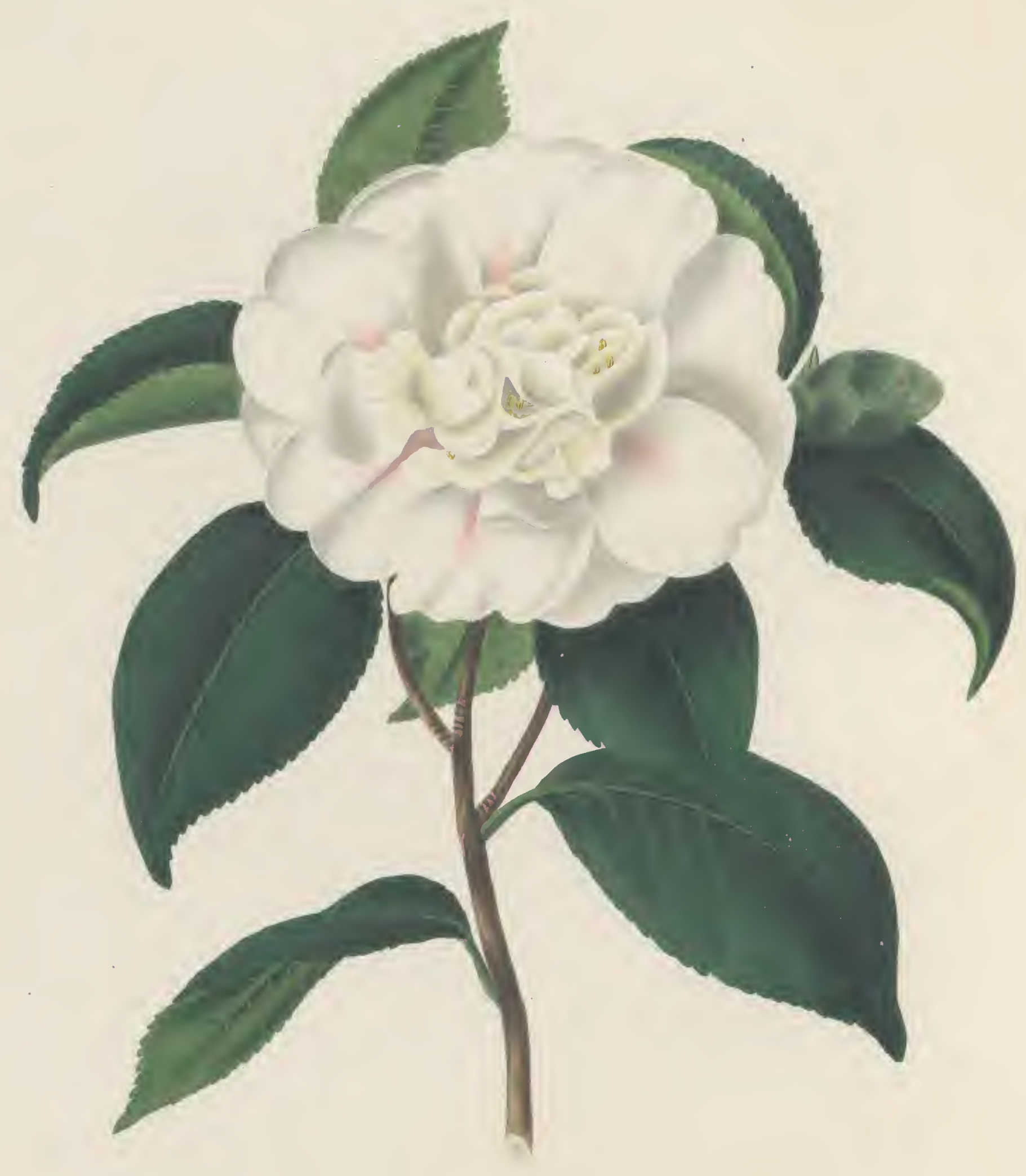

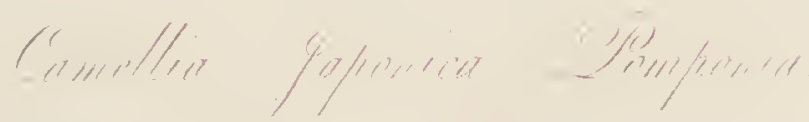



9.

\section{CAMELLIA JAPONICA POMPONIA.}

Pompone Camellia.

Camellia Japonica Pomponia. Bot. Register, t. 22. Loddiges's Bot. Cabinet, t. 596. Pompone, or Kew Blush Camellia. Curtis's Monograph, pl. 3.

THE habit and general character of this variety so much resembles that of the Pæony-flowered, and Various-flowered, as to render it impossible, when they are not in blossom, to distinguish them from one another. By many it has been considered a doubtful variety; but after having observed it, for several years, invariably produce the same sort of flowers, we are decidedly of opinion that, in this respect, it is as permanent and distinct a variety as any in cultivation. It is very probable that it was first obtained from a sport. of the Variousflowered, which we have occasionally seen with perfect flowers of the Pompone, and the red, white, and blush varieties of the Pæony-flowered, upon the same plant. In growth it is more slender and erect than almost any of the other sorts; the shoots are also of a paler colour, and but thinly clothed with foliage. It is believed to have been first imported for the Royal Garden at Kew, about the year 1810, and is generally known by the name of the Pompone, or Kew Blush Camellia.

The leaves, although comparatively narrow, are of an oval form, much recurved and pointed. They may be said to be usually about three and a half inches long, and rather more than an inch and a half broad, but seldom exceed this size; their edges are slightly revolute, and very sharply serrated. The midrib and veins are conspicuous on the upper side, from being paler than the uniform colour of the leaves, which is always a rich, shining, deep green. The footstalks are upwards of half an inch long, nearly round, or but a very little flattened on the upper side, and of the same colour as the veins and midrib.

The flower buds are at first a good deal pointed, but afterwards they become blunt and round. The scales are thin and roundish, of a dull silvery green colour, slightly covered with pubescence.

The flowers are very delicate and showy, measuring, when fully expanded, from three and a half to four inches in diameter. They 
consist of ten or twelve large outer petals, arranged in two rows round a great number of smaller ones, that rise in the centre of the flower, in an erect irregular mass. These outer petals are each of a roundish cordate form, varying from an inch to an inch and a half in breadth. They are at first slightly concave, but gradually spread open, until they become almost flat. In some flowers they are entire, and recurved at the edges; generally, however, they are indented, or partially divided, and undulated. Their colour is pure white, excepting for about a third of their length, nearest the base, which is deeply tinged with red, as well as a small stripe up the centre; the latter very often extends the whole length of the petal, and diminishes in brightness towards the edges. The centre petals are very different from those we have just described, and approach, in some respects, those of the Waratáh, although by no means arranged with the same regularity as in the flowers of that variety. They are all closely united at the base, and rise nearly erect, so that the centre of the flower is considerably elevated. Some of them are more elongated than the rest, and have a tubular appearance, from their edges being rolled back, and compressed together. The greater part, however, are nearly of equal height, and, for half their length, are of a roundish oblong form, ending in a very narrow minute point. They are seldom coloured, unless it is one or two of the large tubular-like petals, which have the same blush tinge as those at the extremity of the flower. Occasionally, a few perfect stamina may be observed, as well as the three united greenish styles; and from its seeds, which sometimes attain maturity, some good varieties have been raised.

It is well represented in the works we have referred to, but in neither of them is it stated when it was first introduced. In the list inserted on the authority of the late Mr. Lee, of Hammersmith, at the end of Mr. Curtis's splendid Monograph, it is mentioned as having been introduced for the Kew Garden, in 1812; but it undoubtedly was known before that time, as it is one of the sorts enumerated in the last edition of the Hortus Kewensis. 



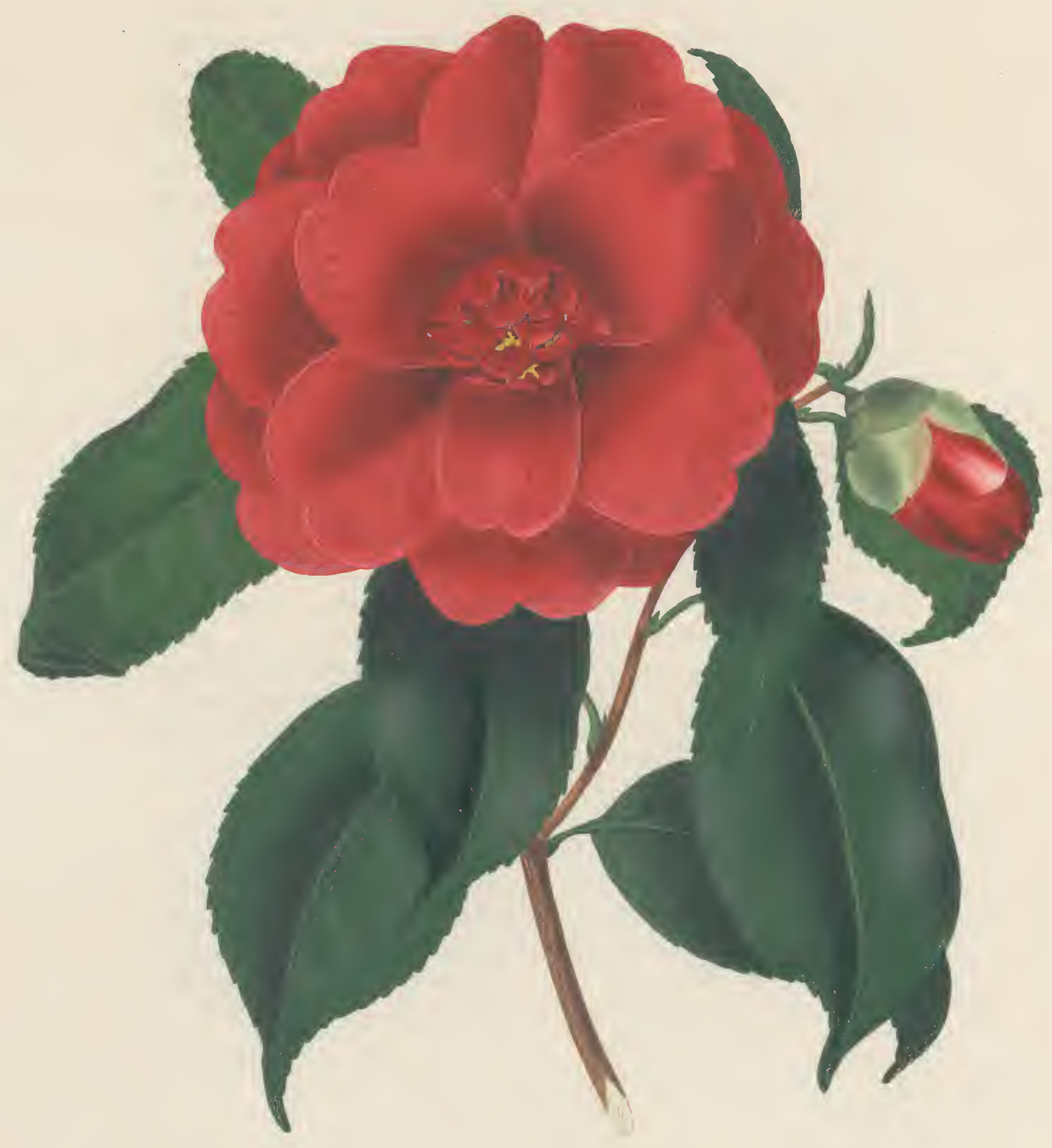

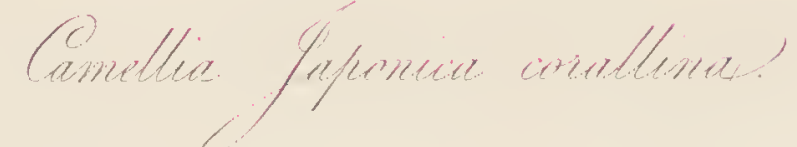




10.

\title{
CAMELLIA JAPONICA CORALLINA.
}

\author{
Coral-Coloured Camellia.
}

Camellia Corallina. Chandler's Camellia Britannica, pl. 5, page 13.

THIS is one of the many fine varieties that have been raised from seed, by Messrs. Chandler, of the Vauxhall Nursery. It originated in 1819, and was first brought into notice, (along with others no less remarkable for their beauty,) by the figure that was given of it in the work above referred to, published in 1825. At that time its merit was only imperfectly known, but it has since been proved to be a variety highly deserving of general cultivation.

Its habit is similar to the Waratáh, from which it was raised; but in growth it seems to be rather more vigorous and bushy. The shoots are of a chesnut colour, and slightly tinged with red when in a young state.

The leaves are pendulous, and partake, in a strong degree, of some of the characters peculiar to those of its parent; they are, however, perfectly distinct from them, measuring upwards of four inches in length, and about two inches in breadth, and tapering to a long narrow recurved point. They are nearly flat, or but a little undulated at the edges, and are always sharply serrated. Their colour is a deep shining green, somewhat paler than that of the Waratáh. They also appear to. be thinner, and more veiny on the upper side than the leaves of that variety, but, in other respects, they are the same. The midrib is prominent, but not very strong, unless toward the footstalk: the latter is comparatively long and slender, nearly round, and of a brownish green colour.

The flower buds are of a large, ovate pointed form, and uneven, in consequence of the outer scales being more concave, and projecting a little above the others. They are very pubescent, and of a pale yellowish green colour. The inner scales are large and thin, often striped, or deeply tinged with red.

The flowers are very attractive, being of a deep crimson red colour, 
and frequently upwards of four inches in diameter. When they begin to open, they are bell-shaped. The outer petals are all nearly of one size and form, generally from twelve to sixteen in number, and ranged in two distinct rows. They are each roundish cordate, about an inch broad in the widest part, rather deeply divided at their extremity, and taper to a narrow, thick, fleshy base. The centre petals are numerous and very peculiar. They are of the same deep red colour as the large outer petals, but scarcely exceed half their length, and rise upright in the centre of the flower in a dense mass, of about an inch in diameter. Each of them has the same sort of small white tip, peculiar to the centre petals of the Waratah; those at the outside of the tuft, or mass, are wedge-shaped, slightly incurved, and rather shorter than those in the centre: the latter are very often faintly striped with white, and irregular in their form, being but partly converted into petals. Upon the whole, however, we may safely say, that, in point of size, and brilliancy of colour, the flowers of the present variety will vie with any which has been introduced. 



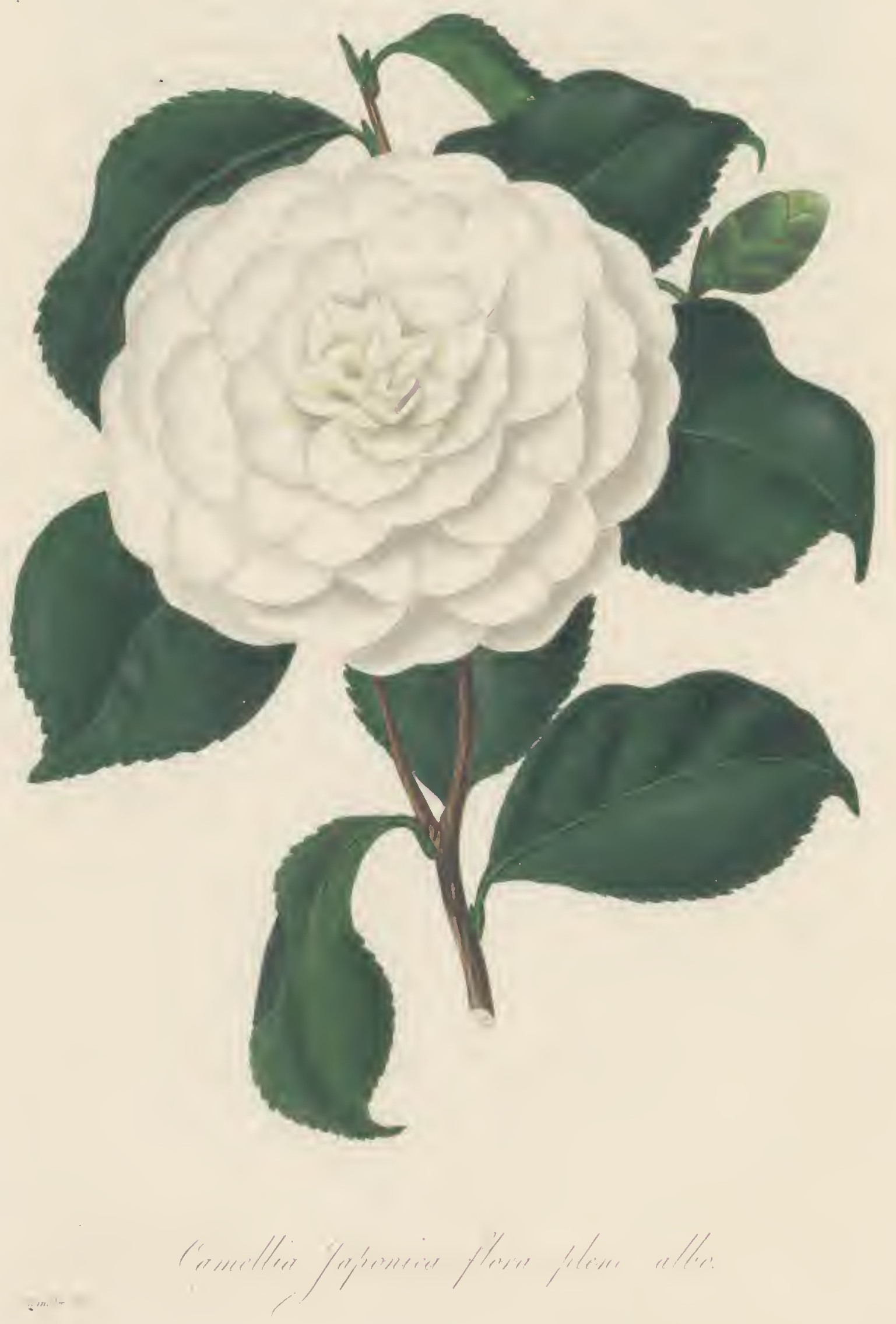




11.

\title{
CAMELLIA JAPONICA FLORE PLENO ALBO.
}

\author{
Double White Camellia.
}

Camellia Japonica flore albo pleno. Botanist's Repository, t. 25. Camellia Japonica alba plena. Loddiges's Bot. Cab. t. 269.

Double White Camellia. Curtis's Monograph, pl. 2.

THE Double White, or, as it has been sometimes called, the "Bourbon Camellia," is one of the most elegant varieties in cultivation. It is also one of the oldest we are acquainted with, having been first brought to this country in 1792 , by the same gentleman who has the honour of being the introducer of the Double-striped, represented at folio 6, of this work. It differs considerably in its habit from the other sorts, and is always readily distinguished from them; being rather less robust in growth, and much paler in the colour of its leaves and branches. It is among the earliest in coming into blossom, and continues longer in perfection than almost any other variety.

The leaves are four inches long, and rather more than two inches broad, ovate acuminate, slightly convex, and undulated. They taper to a long, narrow, somewhat recurved point, and are always very sharply serrated, unless towards the footstalk, where the serratures are generally blunt and indistinct. Their colour is a vivid, shining green, similar to that of the leaves of Lady Hume's Blush variety, figured at folio 7; and, like them, they are strongly reticulated on the upper side, but differ in tapering regularly to both ends, and in not being widest at the point. The midrib and footstalk are both of a pale yellowish green colour; the latter is comparatively short, and nearly round.

The flower buds are often produced in clusters, at the extremity of the shoots; before beginning to swell, they are a little pointed, and of the same colour as the leaves, but when fully grown, they become round, and change to a very delicate silvery green colour. The scales are large, round, and very pubescent, tinged with brown at the edges.

The flowers are from three and a half, to four inches in diameter, and are at all times the most regularly formed of any of the Camellias, the petals being disposed in a series of circles, from the circumference to 
the centre of the flower, and laid particularly flat and even, over one another. They are of a pure white colour, excepting a small number of the centre petals, which frequently have a very delicate yellowish tinge at their base. Most of the petals, on first opening, are slightly involute, or incurved at their edges, and even a few of them may occasionally be seen with their edges partly ciliated, in the manner of those of the Fringed Double White. When the flower has been some days open, the outer petals, which are each of a roundish form, and about an inch in diameter, spread nearly flat, and ultimately become so much recurved, that their edges almost touch one another. They gradually diminish in size, the nearer they approach the centre of the flower, in which they are small, erect, and pointed. When not very numerous, the centre is pitted or hollowed, but generally it is elevated, and so completely filled with petals, that not a vestige of stamina can be discovered, and the flower altogether has the appearance of a large imbricated white globe.

It is one of the varieties most esteemed in China, as well as in this country, where it is now a common plant in every Collection. It varies a good deal in the size of its flowers, which are sometimes much smaller than those we have described; but we are not aware of any distinct variety of it being cultivated, with this peculiarity, although one is mentioned in Mr. Curtis's Monograph, p. 8, to have been introduced in 1816, by the late Mr. Lee, of Hammersmith. In 1824, a plant was imported for the Horticultural Society, by their collector, Mr. J. D. Parks, which, on its flowering in 1826, we were inclined to consider perfectly distinct. The same plant, however, in 1827, and the three succeeding years, produced flowers that differed in no respect from those of the Double White above described. 


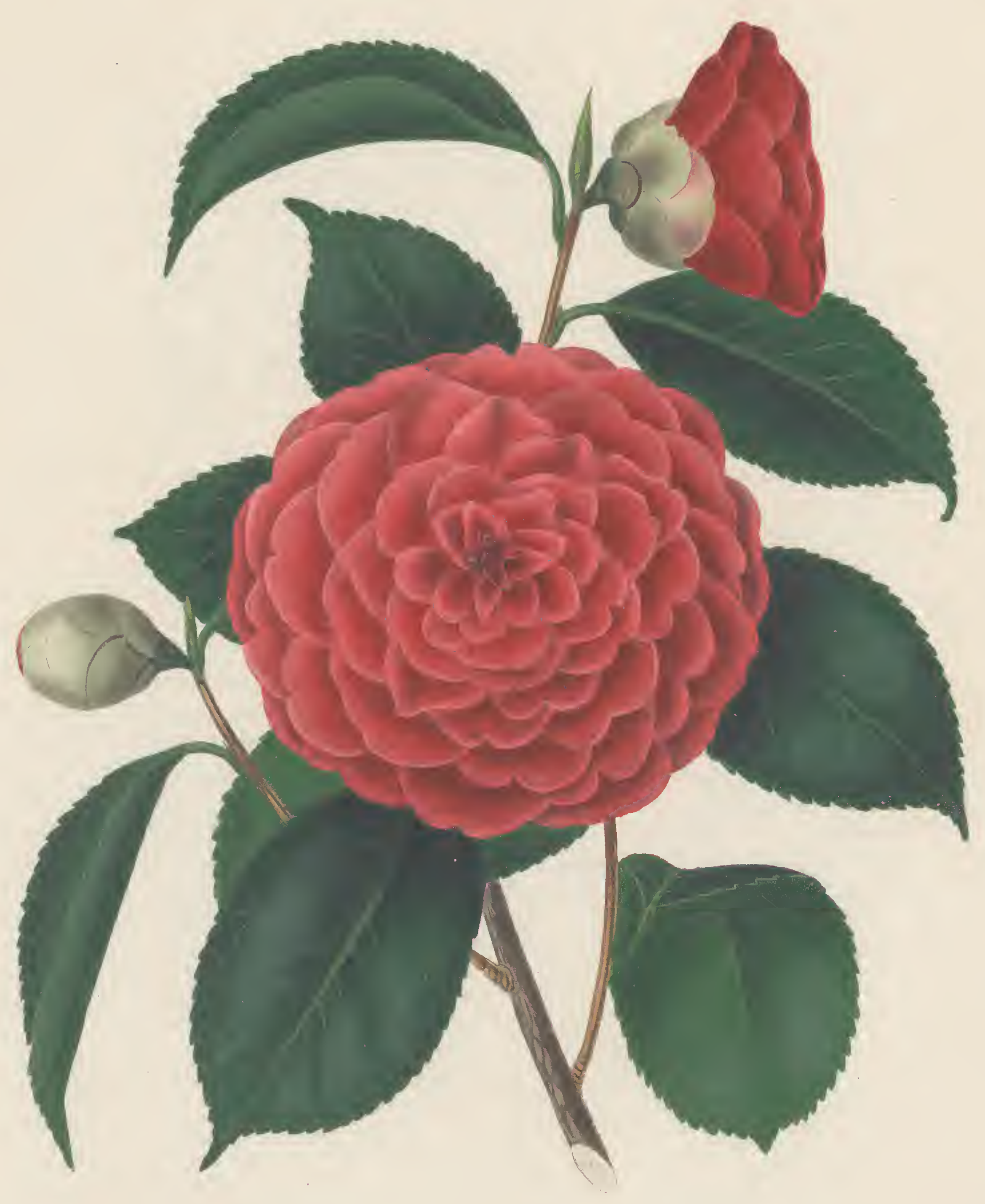

Comellen fafuncia semer 


12.

\section{CAMELLIA JAPONICA EXIMIA.}

Chandler's Choice-flowering Camellia.

THE variety which, it appears, may be obtained from seed, of this beautiful tribe of plants, is almost endless. This is clearly proved by the number which have been added to our Collections during the last few years, from the successful exertions of several distinguished cultivators, among whom we may particularly notice the Hon. and Rev. William Herbert; Messrs. Chandler, of the Vauxhall Nursery; and Mr. Joseph Knight, of the King's Road. The difficulty now is, to make a judicious selection of such kinds only, as are of first-rate excellence, and worthy of being placed in the same class with those well-known and admired varieties, which have been imported from China. The present, we think, will be universally allowed to rank in this class, and, in our opinion, is not surpassed by any already belonging to it. We first saw it in flower in March last, in the extensive collection of Messrs. Chandler, Vauxhall, who raised it from seed in 1819.

With its habit we are not sufficiently acquainted as to be able to speak with accuracy; but, from what we have seen, we consider it to be of free growth, resembling, in some respects, the Waratáh, from which it is believed to have been raised. A few years hence, when it shall have become more generally known, we have not the slightest doubt, but it will be found to possess obvious characters peculiar to itself, that will readily distinguish it from any of the other seedling varieties.

The branches are erect, and of a pale brown colour. The leaves are large and flat, about four inches long, and two inches broad; ovate acuminate, sharply serrated, tapering towards the base and point, which is moderately long, narrow, and recurved. They are of a very deep shining green, similar to that of the Waratáh, but more marked with pale-coloured veins on the upper side. The footstalks are round and slender, about an inch in length, and of a dull green colour, a little tinged with brown near the base of the leaf. 
The flower buds are very large and round. The scales are also large, thin, and of a pale green colour, very pubescent.

The flowers are of a deep rose colour, and measure no less than four inches in diameter. They are particularly handsome, and well formed, the petals being as numerous as in the flowers of the Double White, and arranged in a similar manner. The outer petals are large, round, and spreading, a little divided, or notched, at their apex, and about an inch and a half in diameter. The greater number of them are roundish concave, and laid over one another with the utmost regularity, in close but distinct rows, each of which diminishes gradually, from the circumference to the centre of the flower, in the number, as well as in the size and form of its petals : the latter becoming narrow, short, and pointed, and somewhat paler in colour than those at the extremity of the flower. Like the Double White, the centre is considerably elevated and completely filled with petals, forming altogether the most perfect and beautiful double flower, that it is possible to conceive.

In colour and general appearance it assimilates very closely to the variety Imbricata, or Crimson Shell-flowered, lately introduced by the Horticultural Society, but may at once be distinguished from it, by the greater size of its petals, which are rather darker in colour, and notched; not entire, as the petals of that variety. The foliage of the two plants is also totally different and distinct. 



$$
\text { \% }
$$




13.

\section{CAMELLIA JAPONICA WILTONI.}

Lady Wilton's Camellia.

FOR the introduction of this pretty variety, we are indebted to $\mathbf{M r}$. Joseph Knight, of the Exotic Nursery, King's Road, Chelsea, who informs us that he raised it from seed about sixteen years ago. It is, however, little more than six years since it began to be generally known, and cultivated in the neighbourhood of London; although, from what we have just stated, it would appear to have been among the first of the double varieties that were raised from seed in this country. Its parentage cannot now be ascertained with any degree of accuracy. It is not improbable but that it sprang from a seed of the single red Camellia, which had been impregnated with the double-striped; or perhaps it is the produce of the double-striped itself, which not unfrequently brings its seeds to perfection. Be this as it may, it is certainly a desirable, and well-marked variety, and one that is perfectly distinct from either the double-striped, or the two other sorts, which rank next in the colour and form of their flowers; namely, Parks's Rose-striped Camellia, introduced from China by the Horticultural Society; in 1824; and Elphinstoni, another beautiful seedling raised by Mr. Knight.

The original plant, from which our description and the accompanying figure were made, is in Mr. Knight's Collection, and appears to be of free growth, rather slender and bushy. The branches are nearly erect, and are all thickly clothed with large thin, and flat, ovateacuminate, sharply serrated, deep shining green leaves, which are each about four inches and a half long, and two inches broad. They differ materially from those of the common double-striped, as well as from Elphinstoni; to the latter they have the nearest resemblance, but are comparatively thinner, and more pointed, and have smaller serratures. The footstalks are long and slender, a peculiarity which is only common to the Waratáh, and the numerous seedlings which have been obtained from it. They are nearly round, and, together with the midrib and 
veins, which are rather prominent, are of a dull, pale green colour, slightly tinged with brown on the upper side.

The flower buds are very freely produced, and stand well, unless the plants are kept too warm, which is apt to occasion the buds to drop before expansion. They are at first much pointed, and of a deep green colour, with but little pubescence; afterwards they change to a roundish oval form, and become of a yellowish green. The inner scales, which are thin, and nearly round, are occasionally striped with red.

The flowers, which seldom exceed two, or two and a half inches in diameter, are similar in their appearance to those of the double-striped, represented at folio 6 . They are, however, far more regularly formed, and consist of a greater number of petals. Those next the circumference of the flower are almost round, and generally measure about three-fourths of an inch in diameter. They expand quite flat, and ultimately are a little recurved at the edges. Towards the centre, which is considerably elevated, the petals gradually diminish in size, and are disposed with much less regularity than near the circumference of the flower; some of them are twisted, but the greater number may be said to be plain, and of a narrow, roundish-oblong form. In many instances we remarked that a few of the narrowest more resembled stamens than petals, from their being only partly transformed, and having a yellowish tip, apparently the remains of the anther. The usual colour of the flower is a mixture of red and white, of which the former is the most predominant, and is somewhat paler than that of the double-striped. Like that variety it is subject to vary, and will sometimes produce flowers of a pale red colour, with only a few irregular blotches of white on some of the outer petals. 


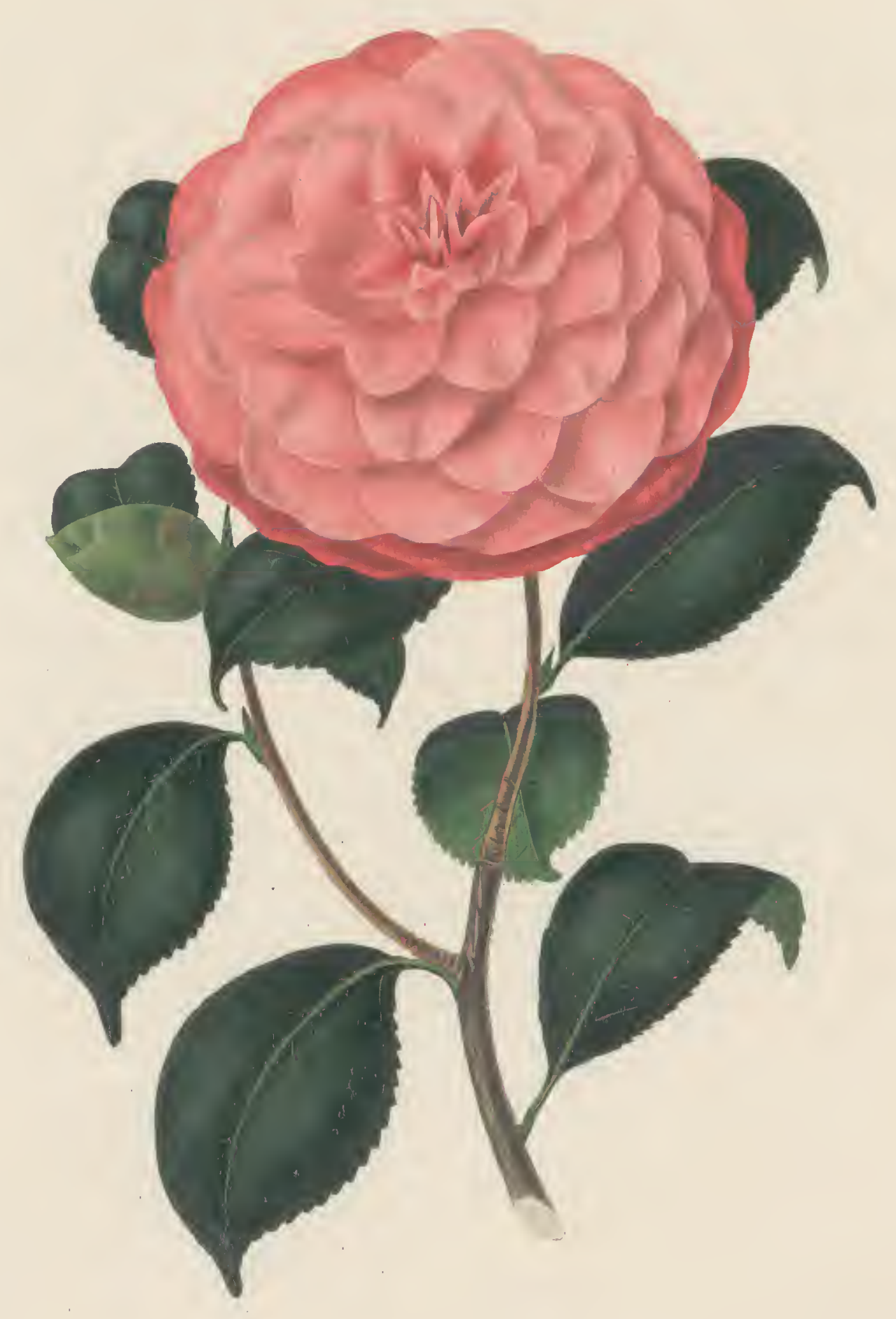

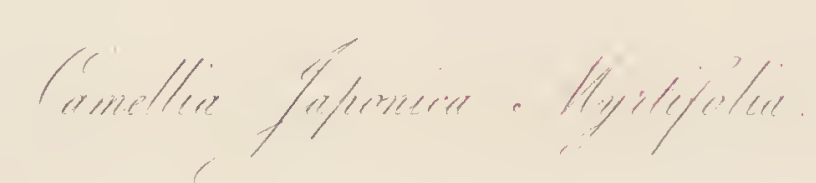



14.

\title{
CAMELLIA JAPONICA MYRTIFOLIA.
}

\author{
Myrtle-leaved Camellia.
}

Camellia Japonica Myrtifolia. Bot. Magazine, t. 1670. Loddiges's Bot. Cabinet, t. 354. Transactions of Hort. Soc.Vol. 7.

Myrtle-leaved Camellia. Curtis's Monograph, pl. 5.

FROM a paper which we had the honour to communicate to the Horticultural Society, and which is printed in the seventh volume of their Transactions, we extract the following account of the variety so faitllfully represented in the annexed engraving.

This sort is of a peculiar habit, and much less robust in its growth than almost any of the other Camellias. In certain soils, and under different kinds of treatment, it is liable to vary a good deal, both in its flowers and foliage, which has given occasion to suppose there were two varieties of it in cultivation, namely, the Large Myrtle-leaved, and Small Myrtle-leaved. The latter name, however, is only applicable to it when the plants are in a young state. They then have weak shoots, with leaves not much larger than those of the common Myrtle, but afterwards they lose this character, become more vigorous, and the supposed two varieties cannot be distinguished from one another. It seems to be rather tender, and succeeds best when the plants are kept warm, and forwarded in their growth in the spring.

The branches are numerous and spreading, with convex, ovateacuminate, sharply serrated, dark shining green leaves, generally about two and a half inches long, and rather more than an inch broad, much twisted and recurved, with a strong, prominent pale-coloured midrib. The footstalks are scarcely half an inch long, nearly round, and of a brownish green on the exposed side.

Flower buds roundish oval, somewhat pointed,with large, roundish, pointed, pale green, slightly pubescent scales: the latter, at the time the buds begin to swell, are of a dull and rather dark green colour.

The flowers are very freely produced, and are large in proportion to the size of the plant, few of them being less than three inches in diameter. They are particularly handsome, and similar in their forma- 
tion to those of the Double White. On first opening they appear of a deep rose colour, but when expanded become paler. The petals are numerous, and regularly arranged over one another, forming a peculiarly nice, even, and compact flower, faintly veined with red. The exterior petals are of a roundish form, always darker in colour than the interior ones. They are each about an inch broad, and become recurved after the flower has been sometime open. The interior petals are much smaller, and pointed, and of a pale rose colour; at first they are erect, concave, and closely set together, so that the centre of the flower is considerably elevated: they afterwards expand almost flat, and leave a little hollow space in the centre, which is very often hid by small, narrow, irregularly formed petals, with a yellowish tip, having the appearance of stamina. The flowers continue a long time in perfection, and are slightly fragrant.

It is generally believed to have been first imported in 1808 , for the Royal Garden, Kew. The figure of it in the Botanical Magazine, was made from a plant which flowered in the Collection of Messrs. Chandler, at Vauxhall, in 1814; but neither in that work, nor in Curtis's Monograph, to which we have also referred, is it stated when it was introduced. Messrs. Loddiges mention it in their Botanical Cabinet, as having been very rare in 1811, when Mr. Aiton presented them with a cutting of it. A few years afterwards it was in great repute, and began to be common in the nurseries about London. It is usually received from China for the Hexangularis, a variety no less remarkable for the regular disposition of its petals, than for the peculiar elegance of its flowers, which are admirably represented in several collections of Chinese drawings we have seen, and particularly in the one belonging to the Horticultural Society. We would almost be inclined to question whether such a variety as this existed in China, if the drawings of the other sorts, which have been introduced from thence, were not in general so accurate, as to place the matter beyond a doubt.

We are acquainted with a plant, which is cultivated in some Collections under the name of the Large-flowering Myrtle-leaved, but which does not appear to be different from the one above described. 



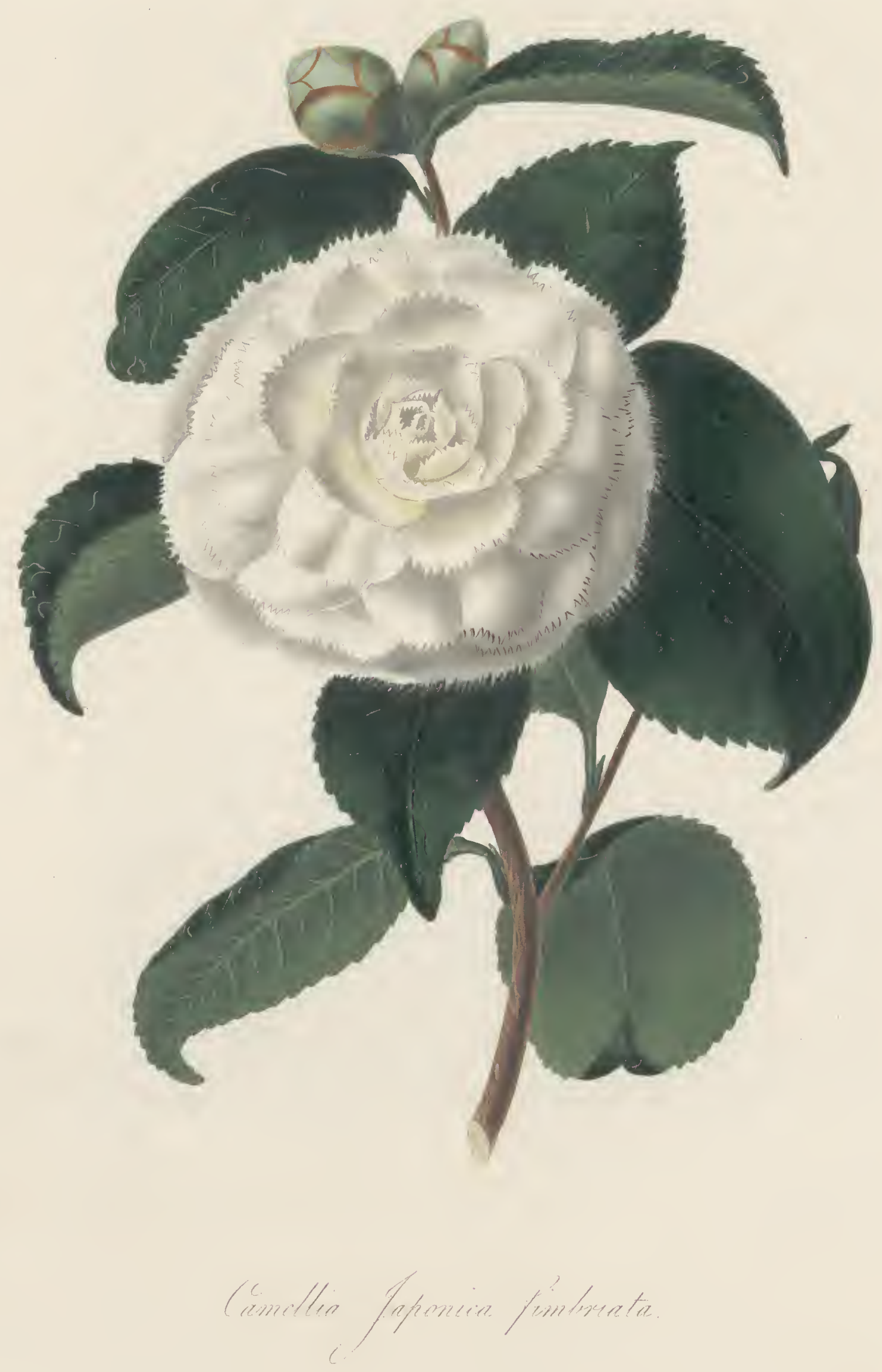




15.

CAMELLIA JAPONICA FIMBRIATA.

Fringed Double White Camellia.

Camellia Japonica Fimbriata. Loddiges's Botanical Cabinet, t. 1109. Transactions of Hort. Soc. Vol. 7.

THE limits of the publication above referred to, in which we have noticed this fine variety, prevented us from entering so minutely into detail respecting it, as we are enabled to do in the present work. We briefly stated that its habit, growth, and general character, coincided almost in every respect with that of the Double White, which we have already figured and described. So far we were perfectly correct; although, upon a more rigid examination of the two sorts, we have remarked, that the habit of the one now under consideration, is rather more loose and branching; and that, in consequence of its flowering less freely than the Double White, it is usually more vigorous in its growth.

The foliage of the two plants is much undulated, and about the same in size and form. The colour is also similar, both being of a vivid, shining green, considerably paler than that of the red flowering varieties, and more marked with pale-coloured veins on the upper side.

The flower buds are large and nearly round, of a pale silvery green colour, densely clothed with pubescence.

The flowers may be described as being about the same size as those of the Double White, with the petals arranged in a similar manner, and with equal regularity over one above another, although not quite so numerous. The outer petals are generally reflexed; the inner somewhat concave, and pointed. The most remarkable character, however, is, that all of them have their edges ciliated, or fringed; a peculiarity not 
common to any other variety we are acquainted with, unless it is Parks's Rose-striped, mentioned at folio 13, which we hope soon to have the opportunity of illustrating.

It was imported about the year 1816, but by whom we have not been able to ascertain. Mr. Colvill, of the King's Road Nursery, has the merit of being the first who brought it into notice, and no Collection ought to be without it. 



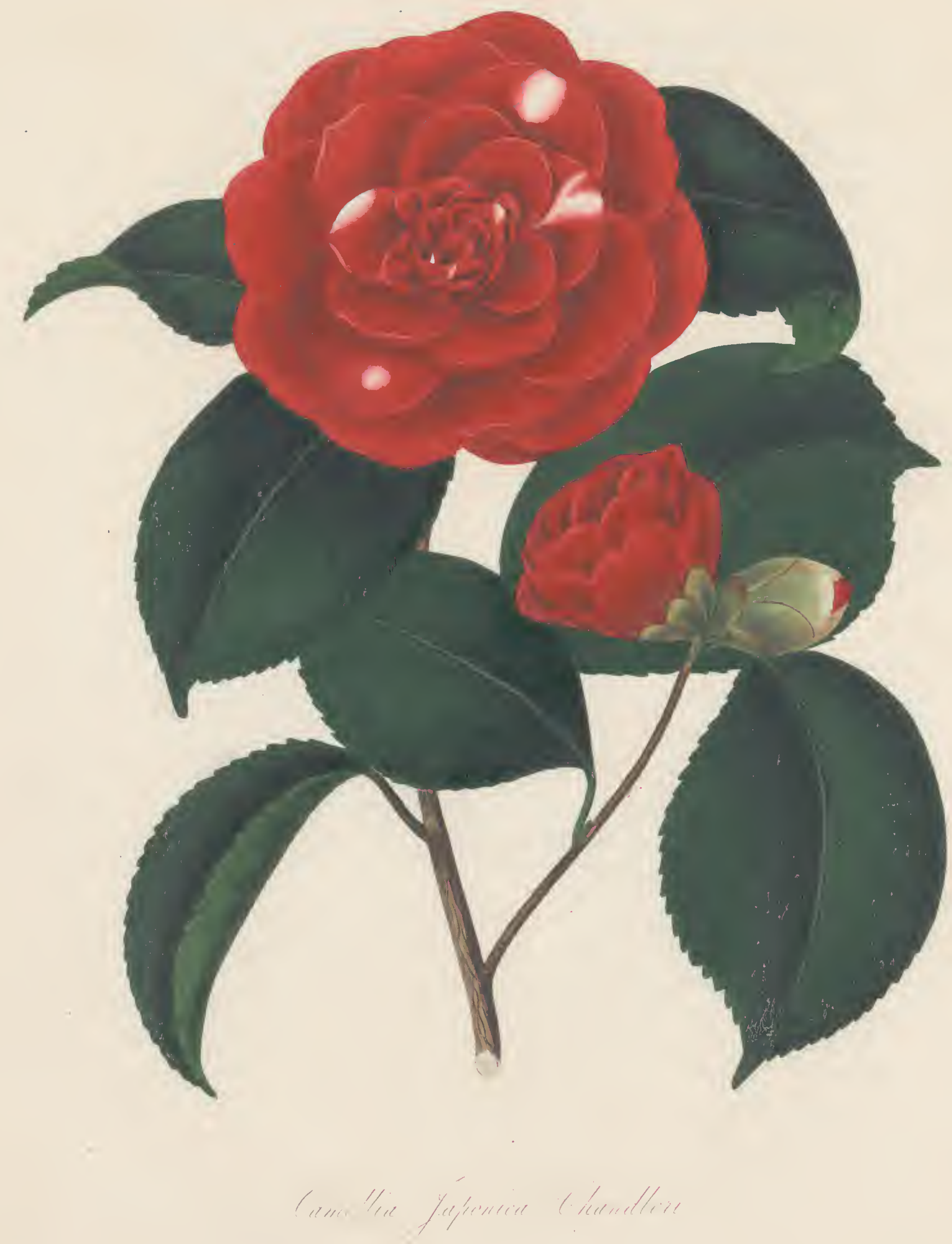




16.

\title{
CAMELLIA JAPONICA CHANDLERI.
}

\author{
Mr. Chandler's Camellia.
}

Camellia Japonica Anemoneflora Variegata. Botanical Register, t. 887. Camellia Chandlerii. Chandler's Camellia Britannica, pl. 1 and 2, p. 7.

THE fine variety now before us, is named in honour of Mr. Chandler, of the Vauxhall Nursery, who has long been celebrated as one of the most successful cultivators of Camellias in this country; and who, we think, on this account, is justly entitled to have his name associated with the tribe of plants to which he has devoted so much of his time and attention.

It originated with him in 1819, and was first made known to the public in 1825, by the figure which was given of it in the Botanical Register above referred to, where it is stated to be the produce of the Waratáh, crossed by the double-striped. The high character it has gained in this country, as well as on the Continent, where it has been very extensively cultivated, confirms us in the opinion we have invariably entertained, of its being one of the very best varieties which has been raised.

The plant, in its habit and general appearance, approaches nearer to the Waratáh, than perhaps to any other variety; but when the two are contrasted together, the present seems to be more vigorous in its growth, and more compact and bushy. The branches when young, are, for the most part, deeply tinged on the upper side with brownish red; they afterwards become of a dark brown colour.

The leaves differ but little from those of the Waratáh, in form and colour. They are, however, somewhat convex, and rounder; with smaller serratures, and a less conspicuous narrow point. The footstalks are also shorter, and not quite so round or slender; the upper side being slightly channelled; in other respects, the leaves of the two varieties appear 'he same. 
The flower buds are more freely produced upon this variety, than upon almost any other with which we are acquainted. They are of a roundish oval form, and of a dull pale green colour, with but little pubescence. A few of them occasionally have brownish-coloured scales, resembling those of the Waratáh.

The flowers are large, and very regularly formed, measuring, when fully expanded, upwards of three inches and a half in diameter. They are of a deep, almost crimson red colour, exceeding in brilliancy that of any of the Chinese Camellias, and not surpassed in this respect by any in cultivation. The petals, though not very numerous, are comparatively large, and of a roundish form, a little divided at the extremity, and incurved at the edges. They are each about an inch and a half in breadth, and seldom spread flat, but rise in distinct circles over one above another. The whole are marked with dark-coloured veins. Sometimes the flowers vary and assume the character of the Waratah, as represented in Camellia Britannica, pl. 1, with the petals more or less marked with white, in the manner of the double-striped; but its usual appearance is like what we have shown in the annexed engraving. 



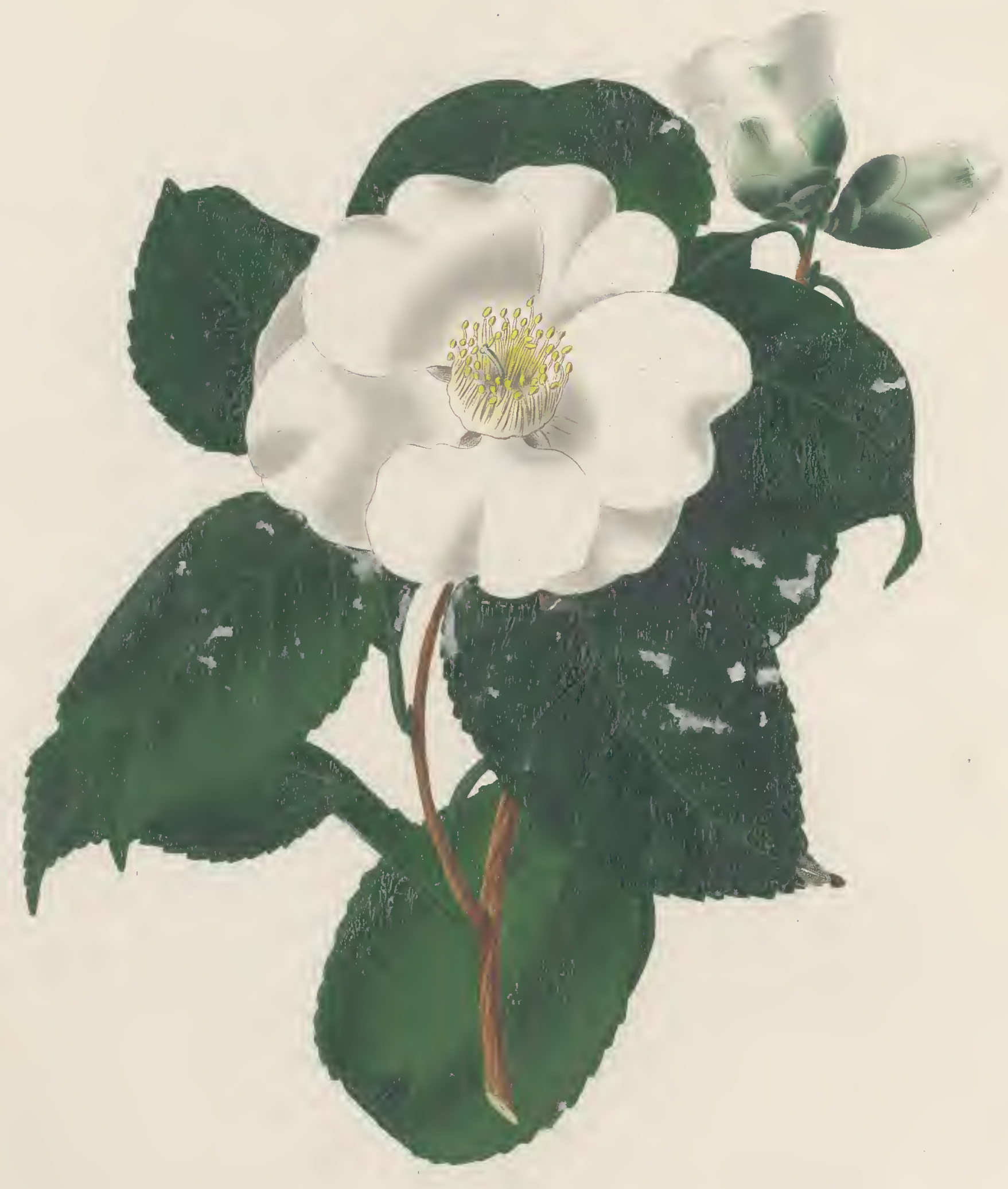

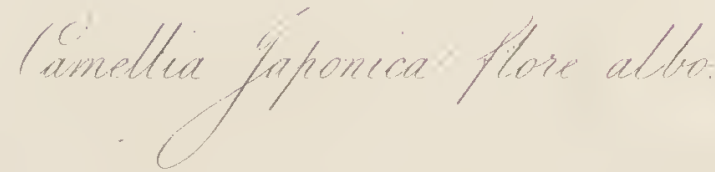




17.

\title{
CAMELLIA JAPONICA FLORE ALBO.
}

Single White Camellia.

\author{
Camellia Japonica, flore albo simplici. Botanical Register, t. 353. Botanical \\ Magazine, t. 2745. Curtis's Monograph, pl. 1. \\ Camellia Japonica Alba. Loddiges's Botanical Cabinet, t. 636.
}

WE have heard many reports concerning the origin of this very distinct variety. Some persons are of opinion that it was imported from China; but we believe it is now generally known to have been raised from seed of the double-striped, by Messrs. Rollisson, of the Tooting Nursery, about seventeen years ago.

In growth and habit, it is more robust than almost any of the other sorts, and is readily distinguished by the great resemblance which its foliage bears to that of its parent. We may however observe that, although similar in form, yet the leaves of the present plant are much thicker and larger than those of the striped, and they are also more recurved and undulated. The serratures are particularly large and sharp. Some of the leaves, indeed, may be more properly described as being dentated, rather than serrated. All of them are of a very dark shining green, and have a strong, prominent, pale-coloured midrib. The footstalks are thick, and seldom exceed a quarter of an inch in length. They are of the same colour as the midrib. The under side is round; the upper is a little flattened, and hollowed towards the base of the leaf.

The flower buds are ovate, and taper to a point; most of them are upwards of an inch long, very pubescent, and of a pale green colour.

The flowers, which are produced in great abundance, usually open earlier in the season than the generality of the other Camellias. They are large and handsome, and consist of from four to six roundish-cordate, white petals, imbricated at the base, and arranged in such a manner as to give the flower an upright, bell-shaped appearance, like that of the single red, represented at folio 1. 
Each of the petals is about an inch and a half in diameter, much undulated, and recurved at the edges. When the flowers have been sometime open, they measure nearly three inches in expansion, and, although generally of a white colour, yet they are not unfrequently striped, or spotted with red. The cup, or column of stamina, with pale coloured filaments, and deep yellow anthers, is the same as in the single red already described.

Within the last few years, it has been ascertained to produce seed freely, and several very fine double varieties, with different coloured flowers, have originated from it. 




18.

\section{CAMELLIA JAPONICA RUBRA PLENA.}

\section{Donble Red Camellia.}

Camellia Japonica, rnbra plena. Loddiges's Botanical Cabinet, t. 397. Transactions of the Hort. Soc. Vol. 7.

Donble Red Camellia. Curtis's Monograph, pl. 3.

Camellia Japonica, flore rubro pleno. Botanist's Repository, t. 199.

SOME confusion exists with regard to this Camellia, from its being cultivated in many Collections under the name of the Old Red, and Greville's Red, both being considered distinct varieties; but, after having carefully compared plants with those names, that were subjected to the same kind of treatment, we are satisfied there is no difference whatever between them, their flowers being precisely the same in every respect. It is of a free and robust habit, and grows very erect. The flowers are but sparingly produced before the plant gets old, and attains a considerable size, which is the reason of its not being so much cultivated as many other varieties.

The leaves are usually about four inches long, and two inches broad, tapering to both ends, very sharp pointed, recurved, and undulated, with numerous small sharp serratures. They are of a brownish green, when young; but when grown to their full size, are of a dark shining green. The midrib is prominent, and moderately strong. The footstalk is half an inch long, nearly round, and of a pale brownish green colour.

The flower buds are oval, somewhat pointed, generally of a dull green, and slightly clothed with pubescence, becoming brown before the flowers open, like the buds of the Waratáh.

The flowers are about three, or three and a half inches in diameter, and open at the same time as those of the Waratáh and Atro-rubens. They are of a crimson red colour, and resemble the flowers of a large Double Hibiscus. The petals are numerous, of an irregular shape, comparatively long, narrow, and pointed; all of them are veined. The ex- 
terior ones are soldom an inch in breadth when spread out, and do not lie flat over one another, but are much undulated, and unequal in length, which causes the flower to have a starry. appearance. The interior petals are also undulated, and pointed, with their edges compressed, so as almost to meet. They are nearly upright, and diminish in size towards the centre of the flower, which is not elevated, although it is more filled with petals than in those flowers where it is pitted. Sometimes the flower has a different appearance, and is then mistaken for another variety, the petals being smaller than those we have described, similar in colour and formation, but fewer in number, and more regularly arranged, with several parcels of stamina in the centre.

It was first imported in 1794, by Sir Robert Preston, Bart. of Valleyfield, who then lived at Woodford in Essex, where he possessed a choice collection of plants, which he cultivated most successfully. It has been figured in three of the works above quoted, but in neither of them is it mentioned as being like Greville's Red Camellia, or that a variety similar to it was cultivated under that name. 



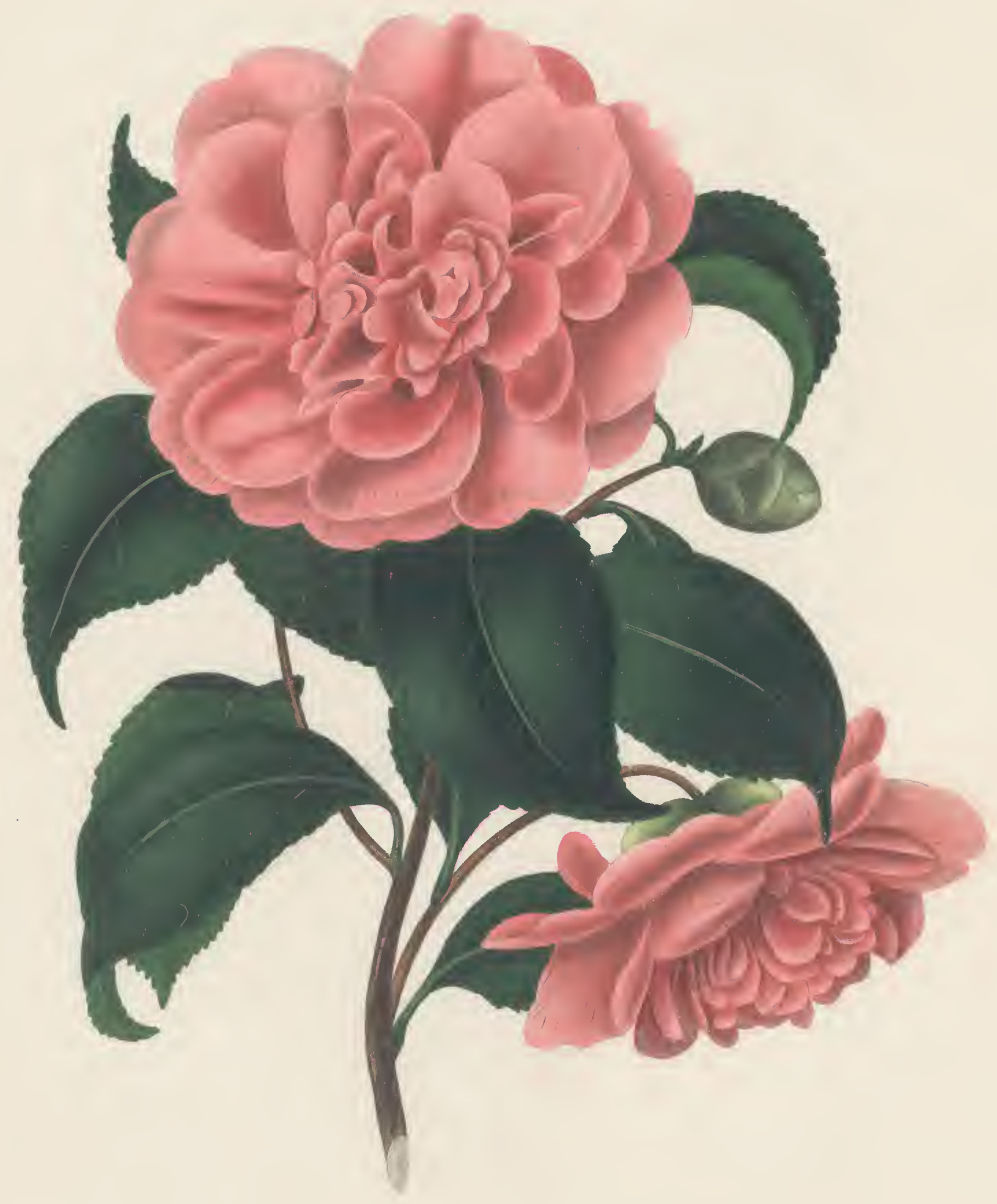

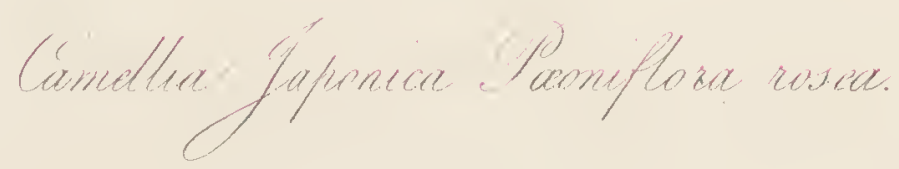




19.

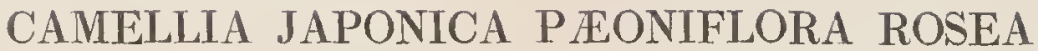

Red Pcony-flowered Camellia.

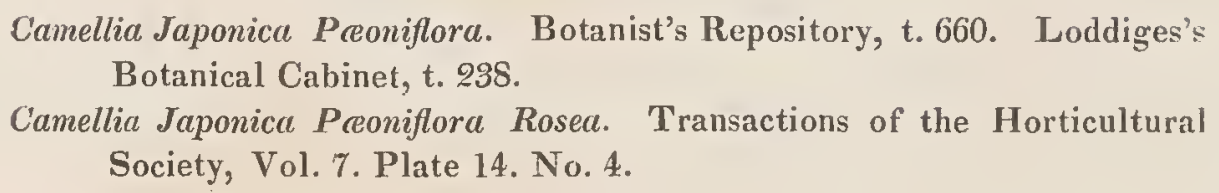

IN our account of the Pompone Camellia, at fol. 9, we have mentioned three varieties of the Pæony-flowered, and hinted at the probability of the whole having been originally obtained from the Various-flowered. We were led to form this conjecture from having seen branches of the latter variety that were grafted, continue to produce perfect flowers of the Pompone, and Red and Blush Pæony-flowered, upon separate plants, without shewing the least disposition to vary, or return to the changeable character of the plant from which they originated. The point, however, cannot be satisfactorily determined; but certain it is, that, unless when in flower, neither of the above-named varieties can be distinguished from one another; all of them being the same in habit, growth, and foliage. Even the flowers only differ in colour. Those of the present variety are of a bright rose, marked with darker-coloured veins. Their size and form, and the arrangement of the petals, is in every way similar to that of the Pompone already described, which , renders it unnecessary for us to enter into a minute detail respecting it.

It is believed to have been first imported by Captain Welbank, for Charles Hampden Turner, Esq., of Rooksnest, Surrey, about the year 1810. A faithful representation of it, and of the two other varieties of Pæony-flowered, with the Pompone, will be found in the Transactions of the Horticultural Society, Vol. 7. plate 14. In the Botanist's Repository, and Loddiges's Botanical Cabinet, there are also tolerably good figures of it. 



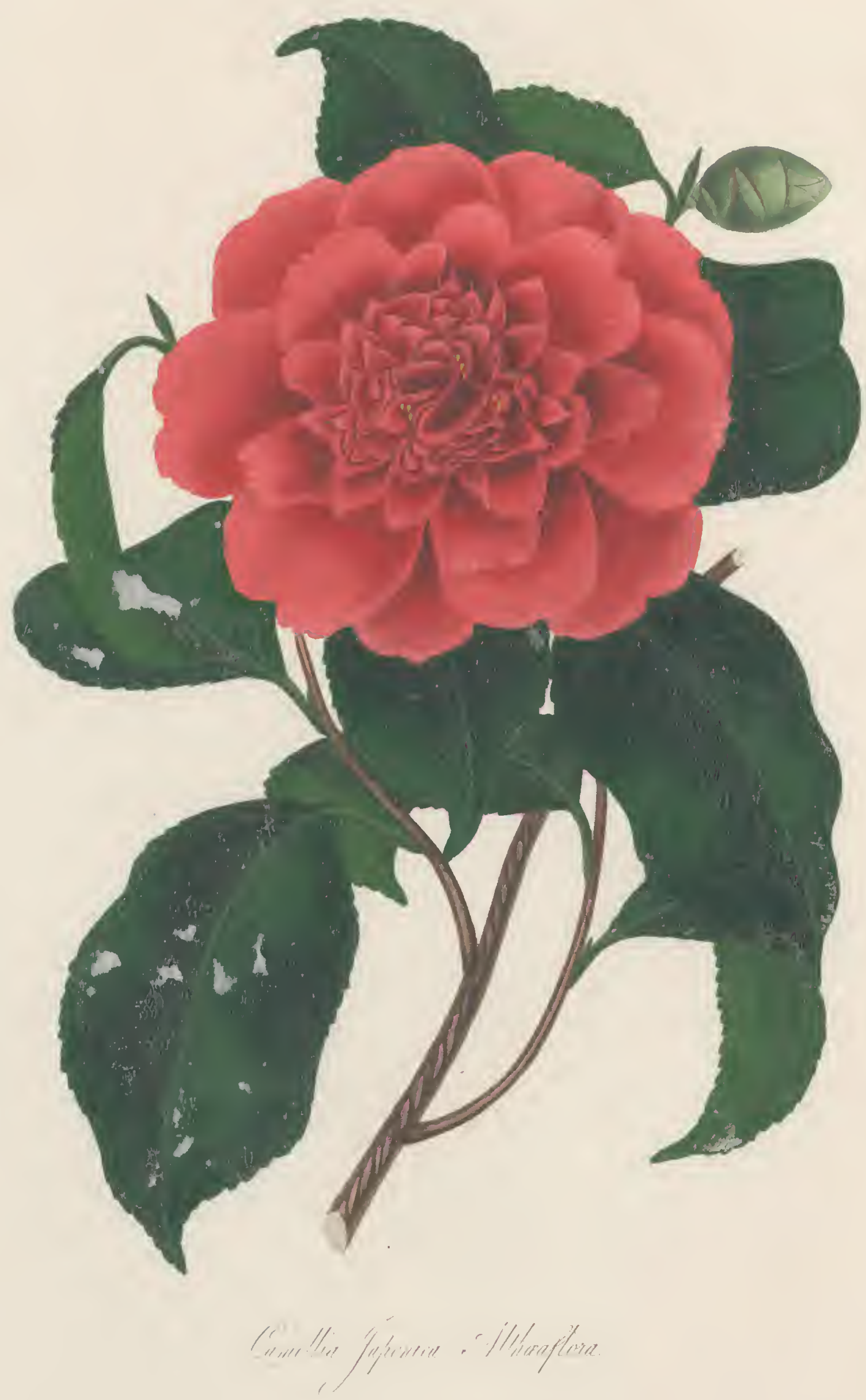




20.

\section{CAMELLIA JAPONICA ALTHÆAFLORA.}

\section{Hollyhock-flowered Camellia.}

Camellia Althreaflora. Chandler's Camellia Britannica, pl. 4.

THIS is another seedling variety, of great merit, which we owe to Mr. Chandler, of the Vauxhall Nursery, where it was raised in 1819. We first remember to have seen it in the spring of 1826, when it was rare, and only little known; since then, we have had ample means of estimating its properties, and can now with confidence recommend it, as a variety deserving of a place in every Collection. Its appearance at once bespeaks it to have sprung from the Waratáh; but, although it closely resembles that variety in growth and foliage, it is, nevertheless, very different in the colour, size, and form of its flowers. This will be obvious to any one the least acquainted with the Waratáh, when they see the annexed engraving, which admirably displays the character of our present subject.

The branches are nearly erect, and of a deep, brownish, red colour. The leaves are all about the same size and colour as those of the Waratáh, but they differ in being more sharply serrated, as well as in having: a broader and less conspicuous recurved point. The footstalks are round and slender, deeply tinged with brownish red on the exposed side.

The flower buds are comparatively long, and of nearly an oval form, tapering regularly towards the point. At first they are of a dull green, but as they begin to open, the scales become thin, and of a pale silvery green colour. A few of the inner ones are sometimes tinged with red.

The flowers measure four inches in diameter, and are of a rich crimson red colour, a little paler than that of the Waratáh, but ranking between it and the double red, to which they have some distant resemblance. The outer petals are ranged in two rows, and lie tolerably flat and even over one another. Each petal, when spread out, is about 
an inch and a half broad at the extremity, and of a roundish oblong form, with the edges slightly divided. The centre petals are much shorter than those at the circumference of the flower, and rise upright, like the centre petals of the Waratáh. They are, however, not so numerous, nor so regularly arranged. All of them are uneven, a little cut at the edges, and faintly marked with dark-coloured veins. When the flower is fully expanded, it has a very fine appearance, resembling that of a large double red Hollyhock, on which account we think it has been very appropriately named. 


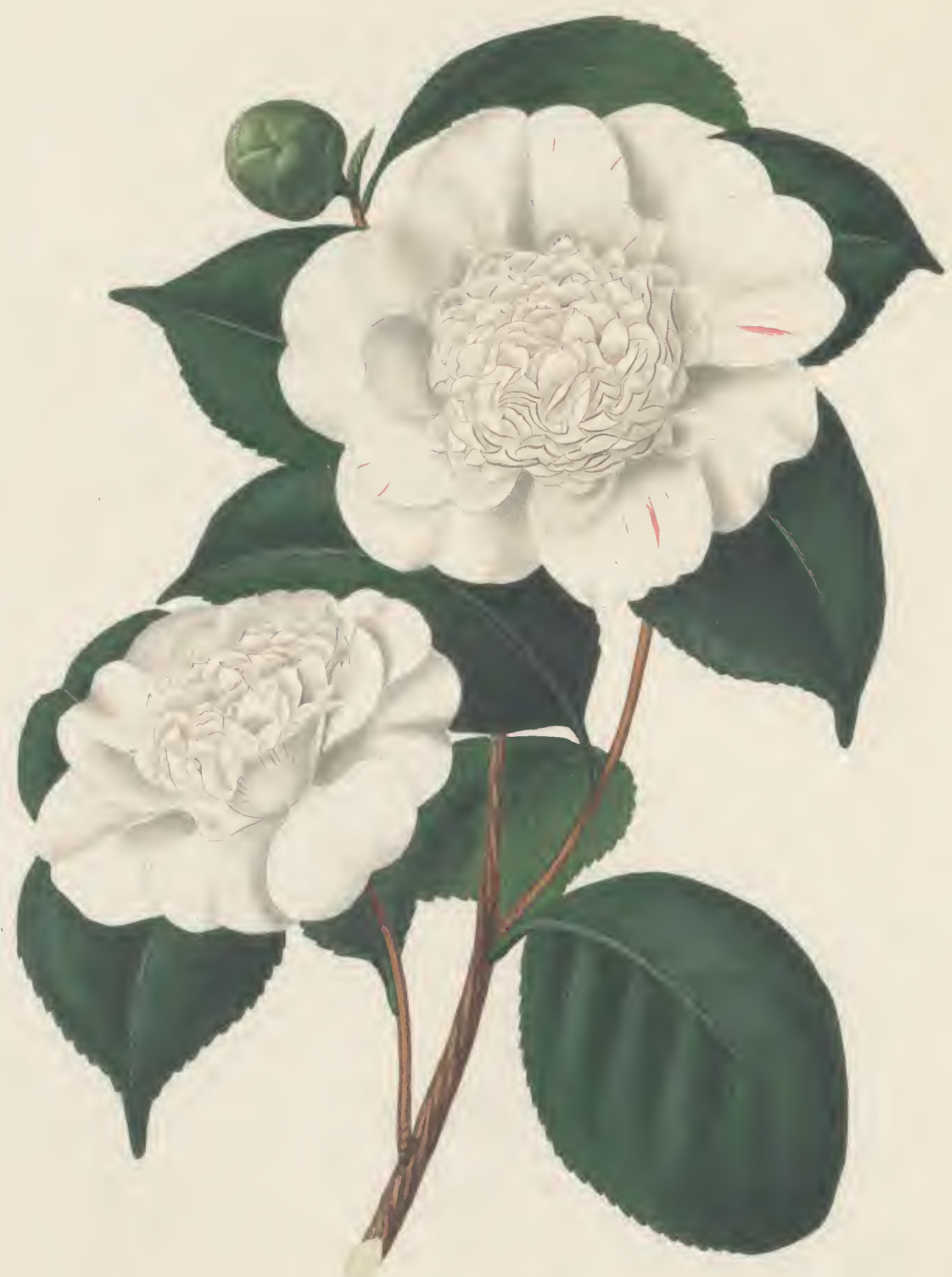

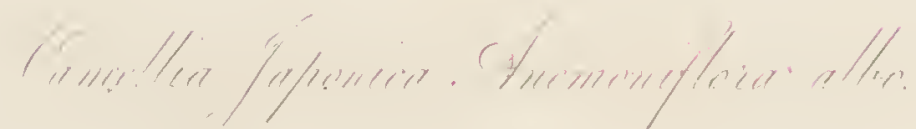




21.

\title{
CAMELLIA JAPONICA ANEMONIFLORA ALBA.
}

\author{
White Anemone-flowered Camellia.
}

Camellia Anemoniflora Alba. Camellia Britannica, pl. 8. White Waratáh Camellia of the Gardens.

WE have elsewhere remarked, that some good varieties have been obtained from seed of the Pompone. The present is one of them, which, we learn from the work above quoted, where it is figured, was produced at the Vauxhall Nursery, with four others, from five seeds contained in a capsule of the Pompone sown in November, 1819.

The habit and general appearance of the plant are much the same as that of its parent. The branches are pale-coloured, erect, and slender. The leaves are stated, in the Camellia Britannica, to resemble the striped in shape, but they are of a lighter green, with more prominent veins. In our opinion, they approximate nearer, in form and colour, to the leaves of the Pompone and Pæony-flowered varieties, than to any other. They are, however, broader at the base, more veiny on the upper side, and have a stronger midrib.

The flower buds are comparatively large and round, with thin, pale green, slightly pubescent scales. They are produced very freely, and have the good property of not dropping off before expansion, as the buds of some of the other varieties are apt to do.

The flowers are about the same size as those of the Pompone, which they also very much resemble in the form and disposition of the petals. They seldom exceed three inches and a half, or four inches in expansion, and are of a delicate white colour, a little striped, and occasionally spotted with pale red. The outer petals are large and spreading, about ten in number, and ranged in two rows; some of the mare recurved, and slightly undulated, but the greater part of them are nearly flat, roundish cordate, varying from an inch to an inch and a half in diame- 
ter. The inner petals are small, irregularly shaped, and very numerous. In some flowers, we have observed them pretty evenly arranged, so as to fill the centre, and cause it to have a globular appearance; but their usual character is to be all nearly of equal height, and to rise upright in a dense mass, like the centre petals of the Pompone.

The name of White Waratál, or White Anemone-flowered, which has been given to this variety, is scarcely so appropriate as we could have wished, as it leads us to suppose that, excepting in the colour of its flowers, it is the same as the elegant variety represented at folio 8 . We, however, think it better to adopt the name by which it is now so generally known, than create confusion by giving it a new one. 



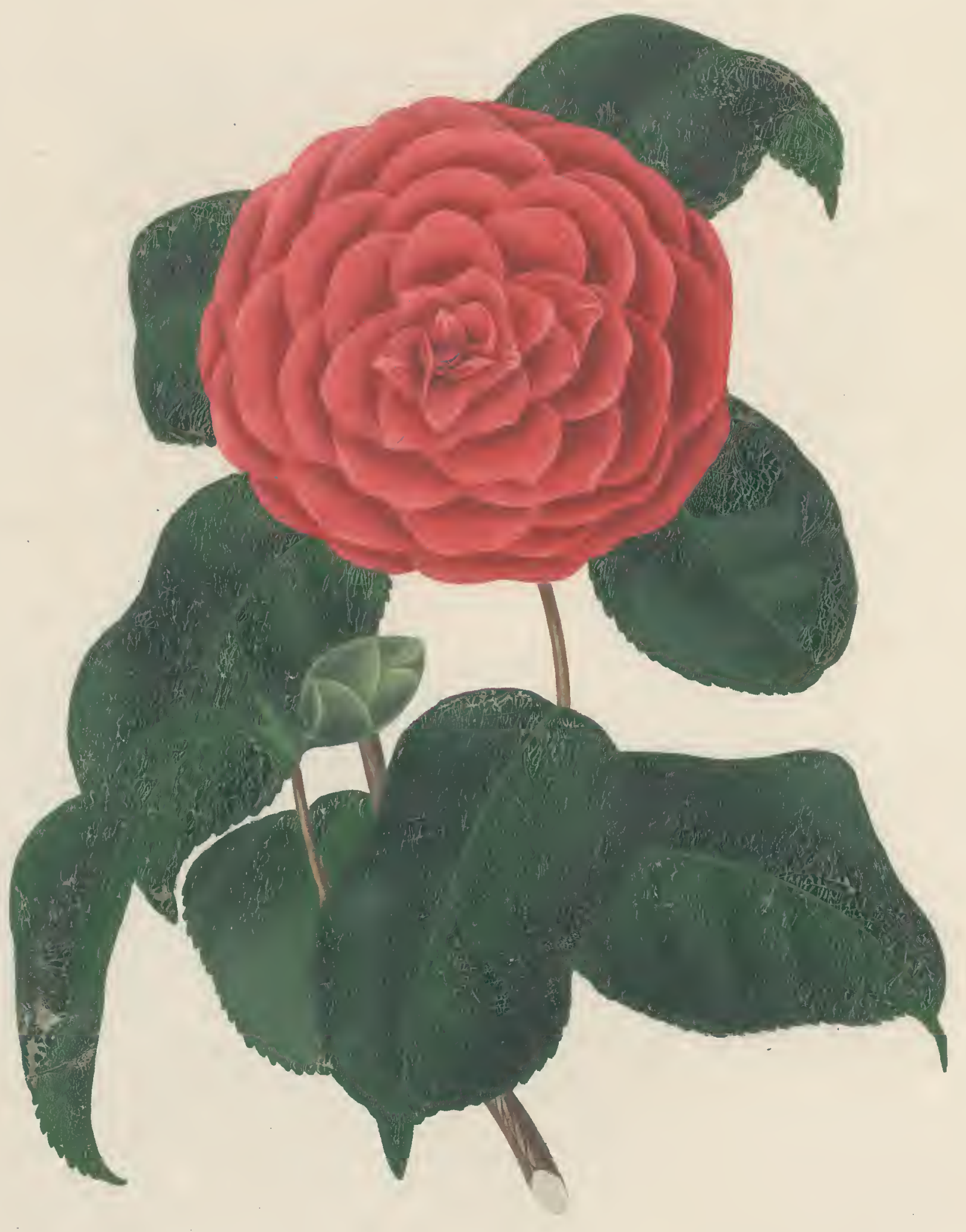

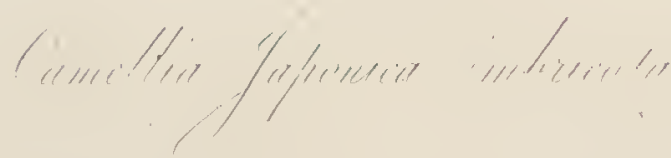




22.

\section{CAMELLIA JAPONICA IMBRICATA}

\section{Crimson-shell Camellia.}

Camellia Japonica Imbricata. Horticultural Transactions, vol. 7.

AT folio 12 , we had occasion to mention this variety, which is unquestionably one of the best that has lately been imported from China.

It is of vigorous growth, with large, thick, dark green leaves, usually four inches and a half long, and from two, to two and a half inches broad, waved and tapering to a sharp point; the serratures are shallow and blunt, and in the old leaves scarcely discernible, especially towards the footstalk. The midrib is prominent and strong, particularly on the under side, and much paler than the leaves. The footstalks are also of a palish green, thick and strong, usually about three quarters of an inch in length, nearly round, excepting on the upper side, which is slightly channelled.

The flower buds are almost round, and very large; the scales are also round, slightly pubescent, and of a palish green, becoming a little brown at the edges, as the flower opens, and tinged with red.

The flowers are upwards of three inches in diameter, and extremely regular in their formation, the petals being ranged one above another, and gradually diminishing in size towards the centre, exactly in the manner of the double-white. The colour is a fine crimson red, and remarkably shewy. The outer petals are nearly round, and are each upwards of an inch in diameter. When the flower begins to open, they are all cupped or concave; but, as it expands, they become quite flat, and those at the extremity are a little recurved.

The centre petals are somewhat pointed, and rise upright. They are so numerous, and laid over one another with so much regularity, that not a single stamen can be observed. Some of the petals between the centre and circumference of the flower, have a faint white stripe, extending. 
from the tip of the petal for about half its length down the centre, but is partially hidden by the other petals covering it; this stripe, however, is not permanent, as it disappears when the flower is fully expanded, or at least becomes slightly coloured with red. The centre of the flower is cupped, and the arrangement of the petals is precisely the same as in the flowers of the double-white.

Representations of it are occasionally met with among Chinese drawings; but the annexed, is the only one which has yet been published of it in this country.

A plant of it was first brought from China, in 1824, by Mr. John Damper Parks, for the Horticultural Society. An institution which we consider to be of national importance, and which we hope will profit by the very proper inquiry that was recently made into its proceedings, so as to become as celebrated for the liberality and fairness of its distributions, as it formerly was notorious for injustice and partiality. Then, and not till then, can such an institution merit, or expect to receive public support. 



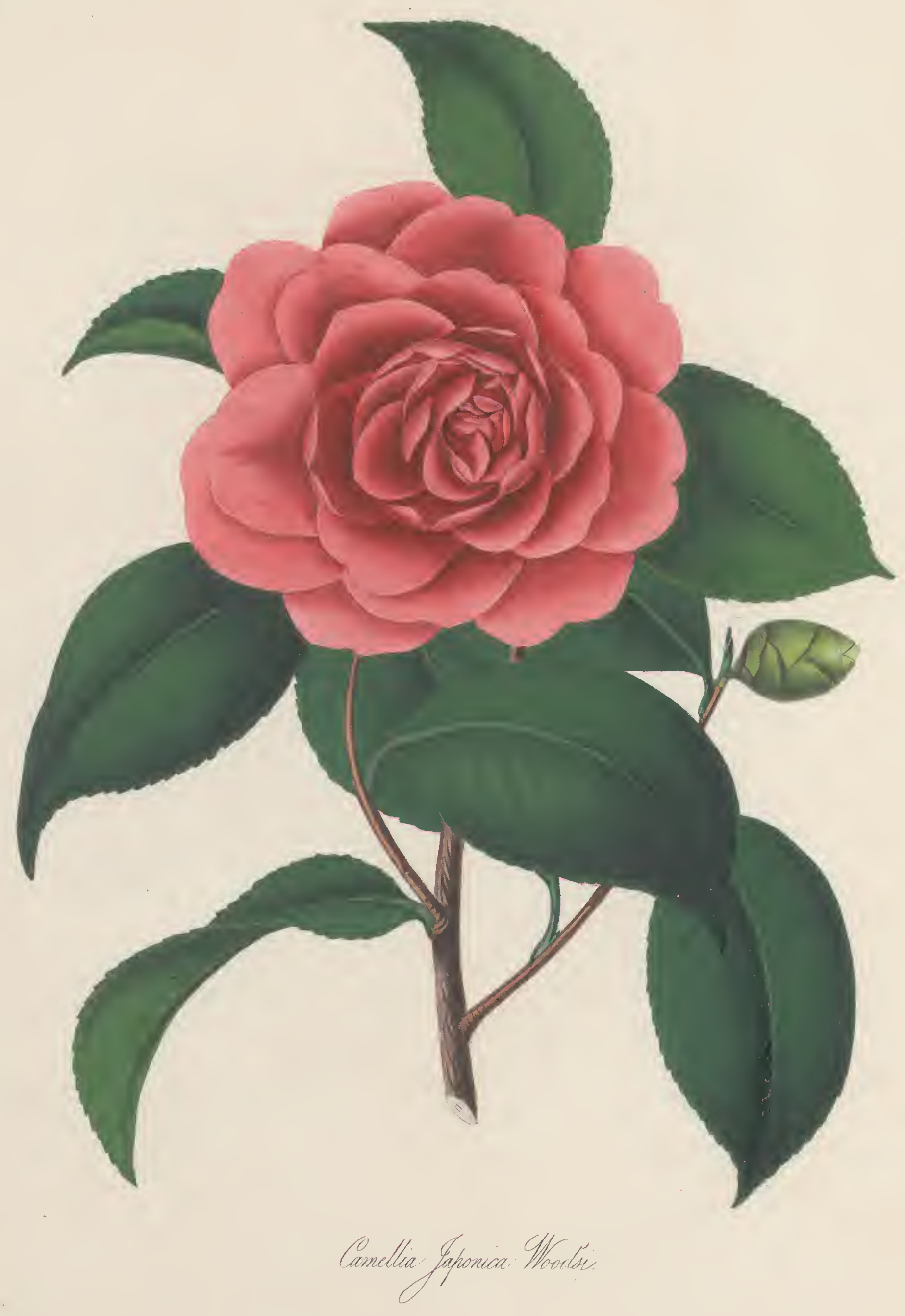




23.

\section{CAMELLIA JAPONICA WOODSII.}

\section{Mr. Wood's Camellia.}

THIS is a variety which we think equals, in beauty, any we have yet laid before the public. It originated with Mr. Chandler at the Vauxhall Nursery, about the year 1819, and was named in compliment to Mr. Woods of Camberwell Grove, who, we understand, is a great admirer of Camellias.

Although a seedling from the Waratáh, it possesses but few of the characters which so readily distinguish that variety from any" other. The branches are upon the whole more vigorous, and of a lighter colour; many of them are rather depressed, after having borne flowers, but their usual habit is to grow nearly erect.

The leaves are large and ovate, tapering gradually from the base, where they are broadest, to a narrow point. They each measure about four inches in length, and two inches in breadth, and are of a deep shining green, a little paler than the Waratáh. They are comparatively thin, and much recurved, with a strong, prominent, pale-coloured midrib. The serratures are large and unequal. The footstalks are moderately long, round, and slender, like those of the Waratáh, and tinged with brown on the upper side.

The flower buds are oval, of a dull green, changing before expansion to a pale silvery green colour. The scales are large, thin, roundish concave, and not very pubescent.

The flowers are particularly handsome and well formed. When fully open, they seldom measure less than four inches in diameter. Their colour is a pale red, similar to that of the common Provins rose, which at a distance they may be said to resemble, excepting that they are larger, and not so double. The whole of the petals are ranged pretty regularly over one another. The exterior ones are large and spreading, of a roundish cordate form, varying from an inch, to an inch and a half 
in breadth. They generally occupy about three distinct rows, and surround a number of smaller petals, which rise nearly upright, in the manner of those of the Waratáh, and give the centre of the flower a similar convex appearance. The small petals are each thick and fleshy at the base; but towards the point, which is blunt and round, they are broad and thin, and occasionally a little incurved. All of them, as well as the large outer petals, are faintly, but distinctly marked with dark-coloured veins. 



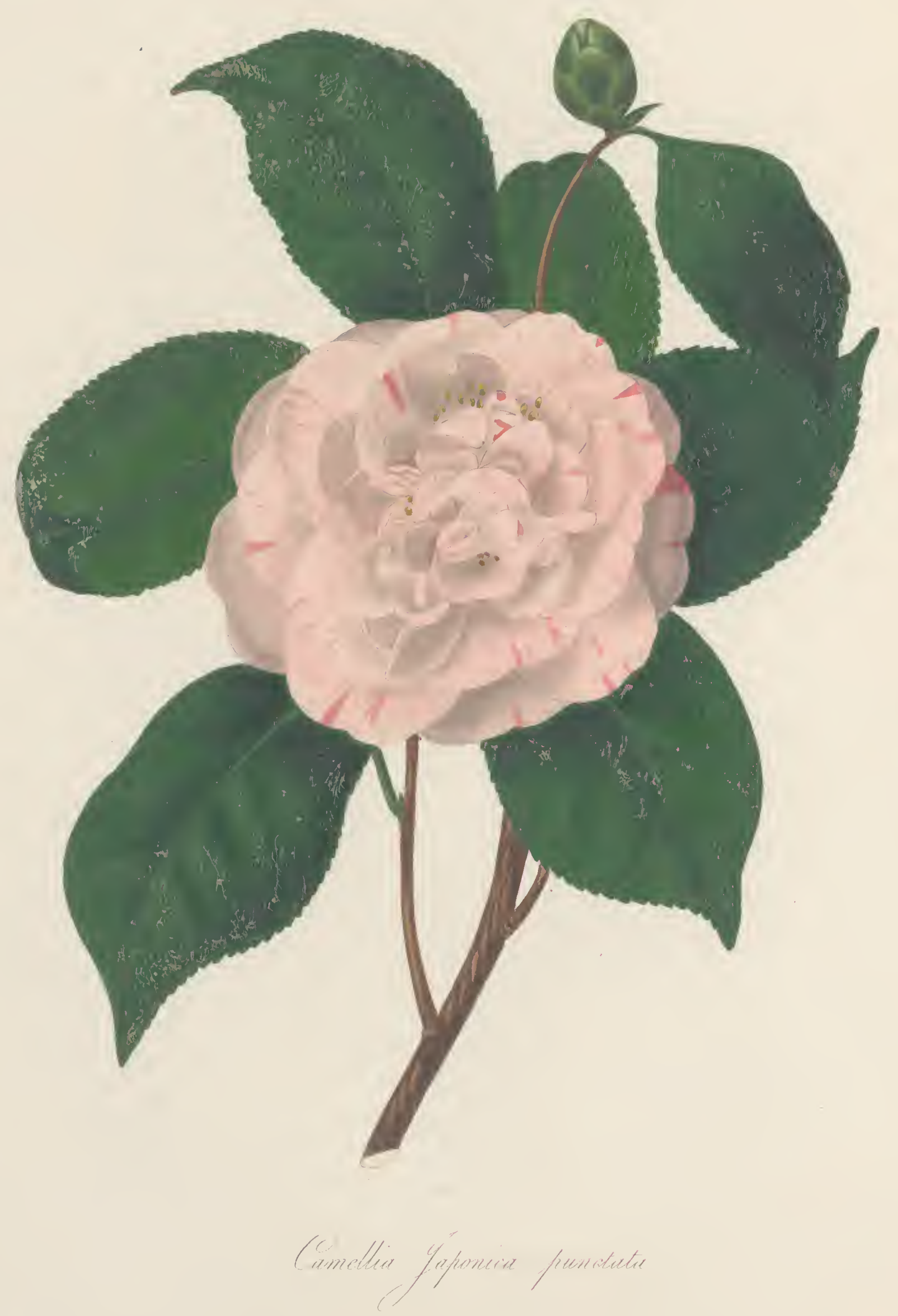



24.

\section{CAMELLIA JAPONICA PUNCTATA.}

\section{Dotted-flowered Camellia.}

Camellia Japonica Punctata. Botanical Register, tab. 1267.

Gray's Invincible Camellia of the Gardens.

WE were favoured, in March 1827, with an opportunity of describing this highly-prized Camellia, and four others, raised by Mr. Press, gardener to Edward Gray, Esq. Harringay House, Hornsey. Shortly afterwards they were made known to the public, by a flower of each of them being exhibited at a meeting of the Horticultural Society, and by a brief description which was subsequently published in the Gardener's Magazine, vol. 2. p. 358, where the variety now before us is mentioned as being the finest of all Camellias. A figure of it was given last year in the Botanical Register above quoted, to accompany which, we had the pleasure of furnishing the following account, at the request of the very respectable Editor of that work.

It was raised in 1824, from seed of the semi-double red, impregnated with the pollen of the single white; to the latter of which it has considerable resemblance, both in its growth and habit.

The leaves are thick, smooth, and of a dark shining green colour, usually about three inches and a half long, and two inches broad, convex, and nearly oval, with moderately large serratures, and a sharp, recurved point. They are seldom undulated, like the leaves of the single white, but have similar prominent veins, and a strong pale green midrib. Footstalks nearly an inch long, a little flattened above, otherwise quite round, and of the same colour as the midrib and veins.

Flower buds large, nearly oval, with seven or eight concave, densely pubescent, green scales, slightly tinged with yellow and pale red at their edges.

The flowers, when fully expanded, vary from three to four inches in diameter, and are of a very delicate blush colour, almost white; striped 
and slightly spotted with pale rose, in the manner of what is known, by florists, as a rose-flake Carnation. The exterior petals are nearly round, or but a very little cordate, and spread almost flat; each of them is upwards of an inch in diameter. The interior petals are numerous, and of an irregular shape, some of them being comparatively large, and roundish, often a little compressed and undulated; they do not lie flat over one another, but are loosely arranged in a cluster, similar to those in the centre of the flower of the Pompone Camellia, represented at folio 9 , of this work, although not so upright or compact. In some of the flowers, a few parcels of stamina may be observed, as is shewn in the figure in the Botanical Register; but they are for the most part all transformed into small narrow petals. 



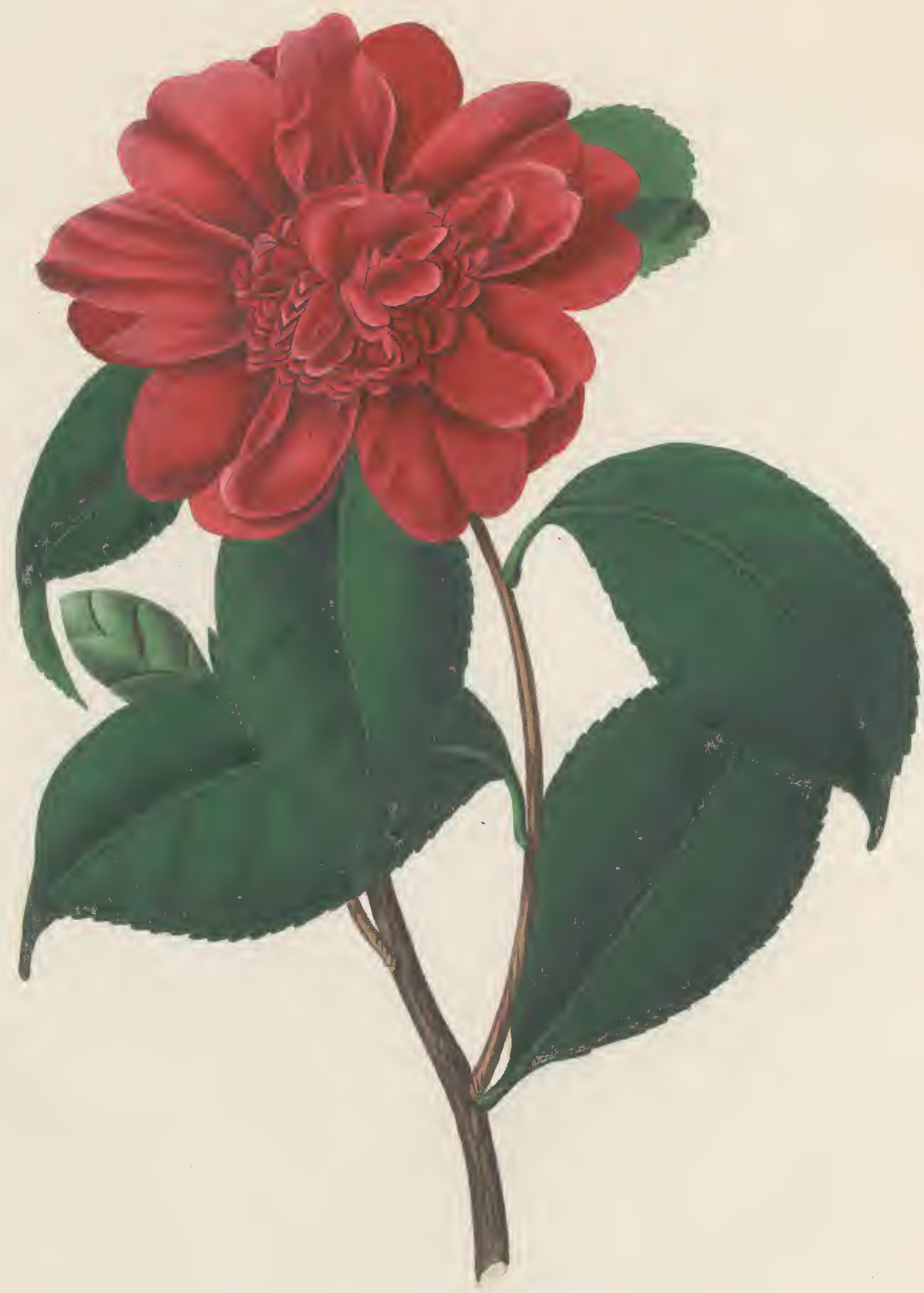

comellia foponera Atioutrens. 


25.

CAMELLIA JAPONICA ATRO-RUBENS.

Loddiges's Red Camellia.

Camellia Japonica Atro-rubens. Loddiges's Botanical Cabinet, t. 170. Transactions of the Horticultural Society, Vol. 7.

A PLANT of this variety was imported from China, by Messrs. Loddiges, in 1809. It is a vigorous growing sort, having long thick erect shoots, of a pale brown colour, somewhat striated. It is always among the latest in coming into blossom, opening about the same time as the Waratáh. The flowers are not very freely produced, but it is nevertheless a handsome and desirable variety.

The leaves are ovate, large and flat, a little recurved at the point, and sharply serrated. They are usually four and a half inches long, and two and a half inches broad, of a dark green colour, not very glossy, with a moderately strong midrib, and numerous prominent palecoloured veins. The footstalks are nearly an inch long, slightly curved at the base of the leaf, and of a dull green colour.

The flower buds are oval, somewhat pointed and pubescent; at first of a dark green, but change to a deep chocolate colour, like the buds of the Waratáh.

The flowers are generally middle-sized, and seldom exceed three inches in diameter. They are very striking at a distance, appearing scarlet. The outside petals are of a thick substance, and expand well; each of them is roundish oblong, about an inch broad, with the edges slightly notched and undulated. The whole are ranged in a double or triple series, and, like most of the other sorts, are faintly marked with dark-coloured veins. The interior of the flower is filled with small petals, confusedly mixed together, varying a good deal in their size and form, but resembling in some respects the centre petals of the Waratáh, each being incurved, and having a very minute white tip. Sometimes, from amongst them, a few larger elongated ligulate petals burst 
out, intermediate, in character and shape, between those at the circumference of the flower, and those in the centre. These are rather of a paler colour, and arranged in a cluster overtopping the others, presenting the appearance of a second flower growing out of the centre. In its usual state, the flower is very neat and showy. 

$\because 0$

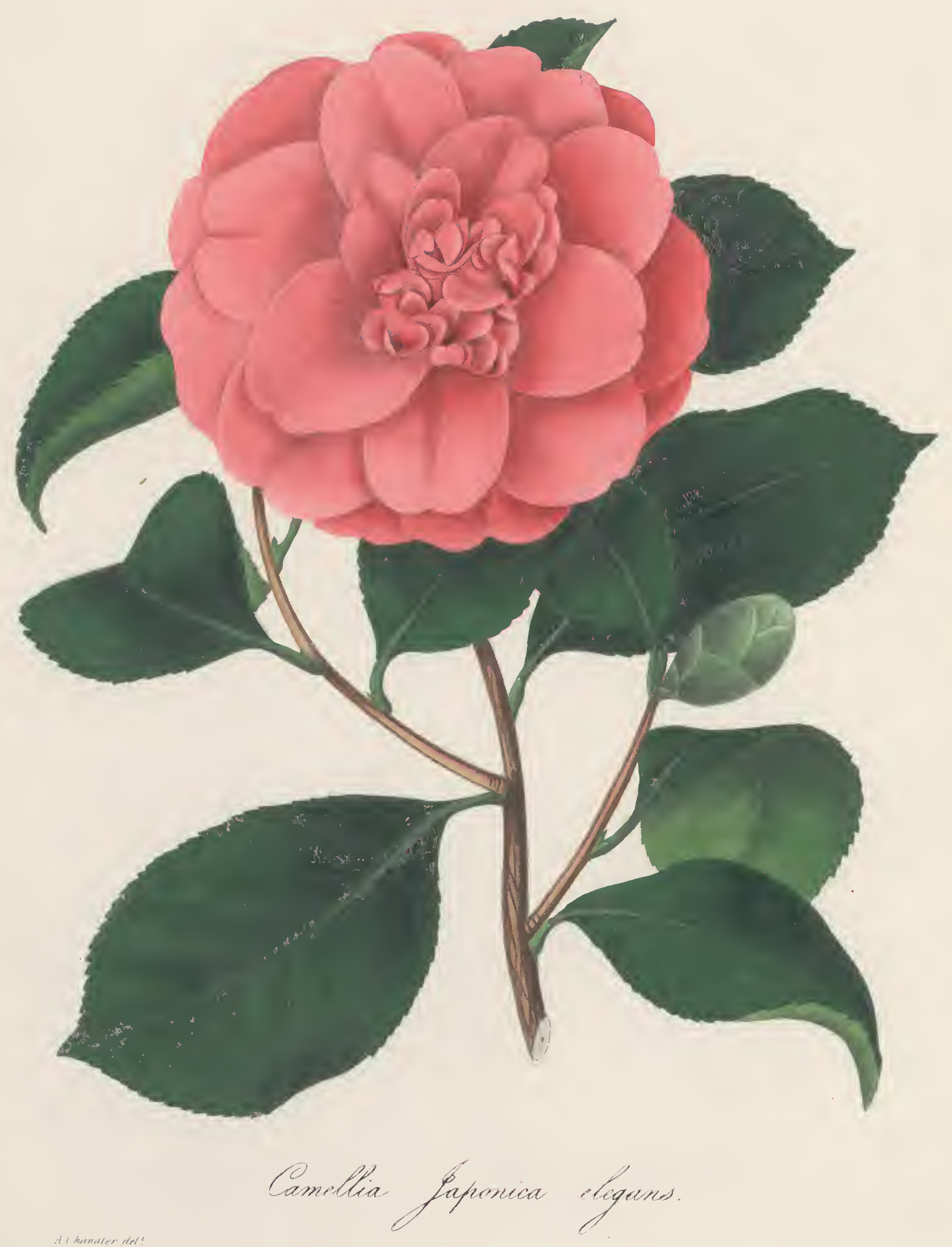



26.

\section{CAMELLIA JAPONICA ELEGANS}

Mr. Chandler's Elegant Camellia.

THIS is another variety which we owe to Mr. Chandler, who raised it from seed of the Waratáh, about eight years ago. It first came under our observation in the beginning of April, 1830, when the plant from which the accompanying figure and description were made, was in high perfection at the Vauxhall Nursery. It appears to be of free growth, and at first sight has some resemblance in its foliage to the Waratah; the two sorts, however, are very different, when compared together. The leaves of the one now before us are large, flat, roundish-oval, with a short recurved point, and numerous small sharp serratures. The midrib is strong, and the veins, which in the Waratáh are scarcely perceptible, are in this variety rather prominent, and of a pale green colour. The footstalks are round and slender, like those of the Waratáh.

The flower buds are nearly oval, or only a little pointed; the scales are large, thin, and round, of a palish green, slightly pubescent, and occasionally tinged with red, like the petals.

The flowers are of a very delicate rose colour, and measure fron three and a half to four inches in expansion. They may be said to rank between the Waratáh and the Pæony-flowered, in their form; but, in other respects, they are distinct from either. The petals are not very numerous, excepting in the centre of the flower, where they are small, and thickly set together; all of them are faintly veined. The outer ones, which are generally arranged in three distinct rows, are large and spreading, few of them being less than an inch in diameter. They are each roundish cordate, and, in the flowers which have been sometime open, are much recurved at the edges. The inner petals are 
rather paler than the outer ones, and vary in their form, some of them being roundish oblong; others narrow, pointed and incurved, with the remains of the yellow anther on the tip, and not unfrequently a small faint stripe in the centre. They are closely ranged over one another, and form a little elevated cone in the centre of the flower, like that of the Waratáh. 



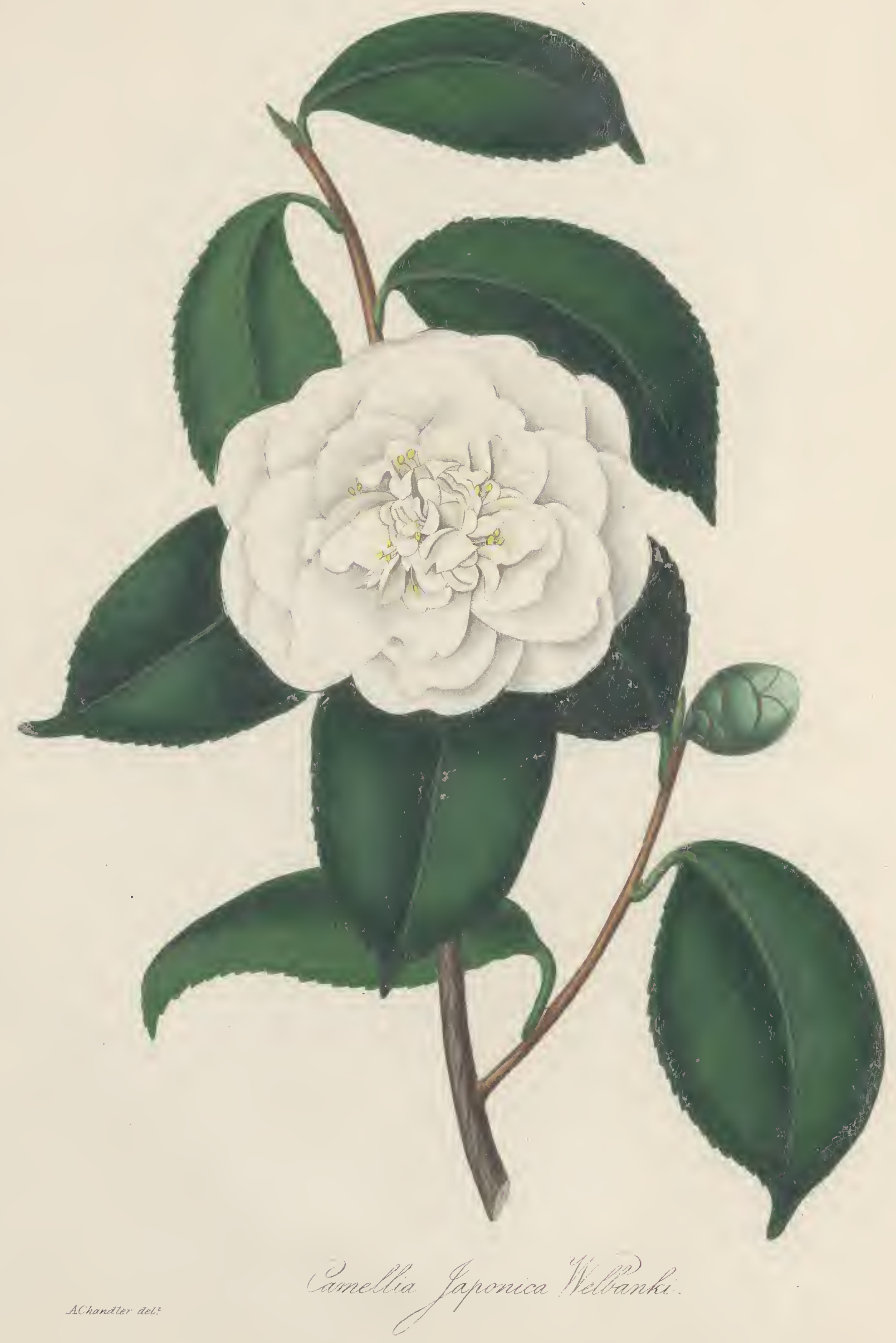


(19) 
27.

\title{
CAMELLIA JAPONICA WELBANKII.
}

\author{
Captain Welbank's White Camellia.
}

\author{
Camellia Japonica Welbankii. Loddiges's Botanical Cabinet, t. 1198. \\ Transactions of the Horticultural Society, Vol. 7. \\ Camellia Japonica Luteo-albicans. Botanical Register, t. 708.
}

THIS sort is very different from any of the other white flowering kinds. It is of a robust habit, and grows very stiff and erect. The branches are of a dark brown colour when young, but change and become paler as they grow old. The foliage, from its convexity, is so peculiar as to give a character to this variety, by which it may always be readily distinguished. It does not appear to flower freely; on which account, perhaps, it is not so much cultivated as it deserves.

The leaves are ovate, from three and a half, to four inches long, and rather more than two inches broad; similar in colour to those of the Pompone, but much more convex, and not so sharply serrated or pointed. The midrib is prominent and strong, particularly on the lower side of the leaf. The footstalk is about half an inch long, nearly round, and of a pale green colour.

The flower buds are large, roundish-oval, covered with several broad and round pale green pubescent scales.

The flowers are of a yellowish white colour, and about three, or three and a half inches in diameter. They may be said to rank between the Double White and the Pompone, assimilating more with the latter than the former, but perfectly distinct from either. The petals are not arranged in any sort of order, so that the flower has a confused appearance. The exterior petals are of a roundish form, from an inch to an inclf and a half in diameter, much undulated, but only a little recurved or divided at their extremity. The centre petals are irregularly shaped; sometimes they resemble those of the Pompone, but are often twisted and arranged in tufts, with several parcels of imperfect stamina inter- 
mixed among them. The flowers, upon the whole, are very delicate, and have been not inaptly compared, by Messrs. Loddiges, to the flowers of the Gardenia Florida, in form and texture.

In the Botanical Register above referred to, where it is figured under the name of Luteo-albicans, it is erroneously stated to have been introduced by the late Mr. Basington, Nurseryman, Stoke Newington. The merit of its introduction belongs to Captain Welbank, in honour of whom it has been named, and who, together with Captain Rawes, imported plants of it in 1820 . 



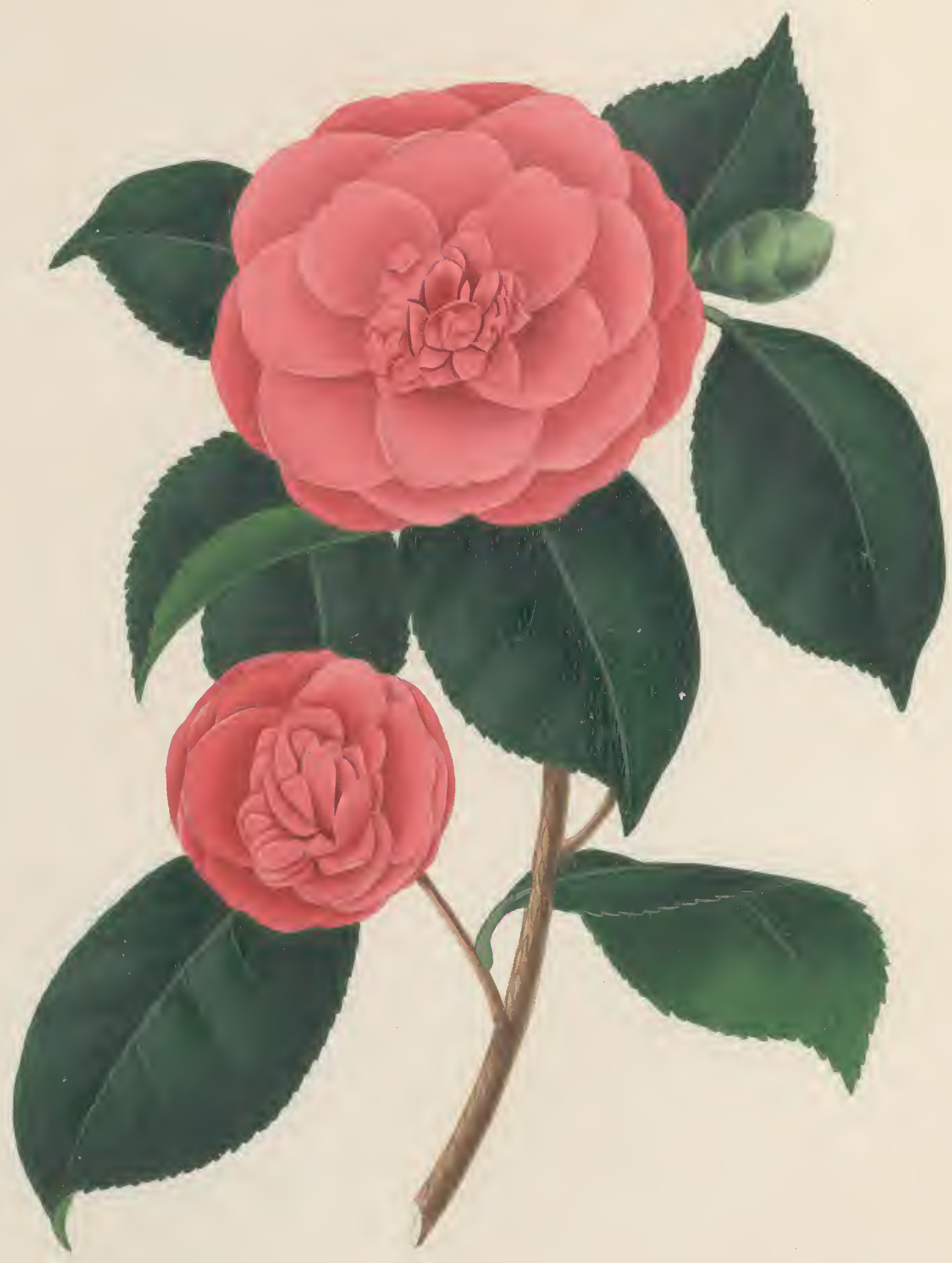

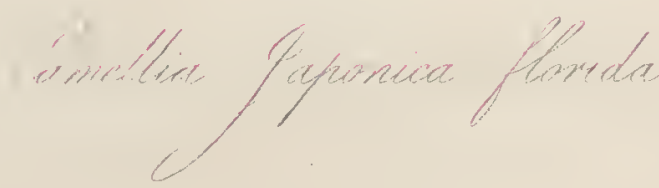




28.

\section{CAMELLIA JAPONICA FLORIDA.}

Cluster-flowering Camellia.

Camellia Japonica Florida. Chandler's Camellia Britannica, pl. 7.

IN the work we have just quoted, this variety is stated to have been produced from seed of the Waratáh, fertilised with the pollen of the Pæony-flowered. To the former it has so great a resemblance, in habit and foliage, as to render it almost unnecessary for us to enter minutely into detail concerning them. We may briefly observe, that the leaves are rather longer and narrower than those of the Waratáh, and of a paler colour; they are likewise more recurved at the point and edges. The principal parts of distinction are in the flower and buds : the latter, although similar to the Waratà in size and form, differ in being of a dull pale green, instead of a dark chocolate colour.

The flowers are produced in great abundance at the extremity of the branches, and open pretty early in the season. They are not large, but are very beautiful, being usually about three inches in diameter, and of a deep rose colour; intermediate between the deep red of the Waratàh, and the bright rose of the Pæony-flowered. The arrangement of the petals is somewhat similar to that of the variety represented at folio 26 ; the outer ones occupying three rows, and expanding nearly flat; there is, however, this difference, that in the flowers of the variety just alluded to, the rows are distinct, or a little separated from one another, whereas in those of the one now before us, they are very closely imbricated. Each of the petals is round, slightly indented at the extremity, and rather more than an inch in diameter. The inner ones are small, roundish oblong, and compactly arranged, like those of the Waratáh, but not 
with such regularity. They are seldom more than half the length of the outer petals, yet the centre of the flower is considerably elevated, in consequence of their rising nearly upright, and being a little incurved at the point.

A tolerably good figure is given of it in the Camellia Britannica, which has been the means of bringing it into general cultivation. The date of its origin we believe to be 1819 . 



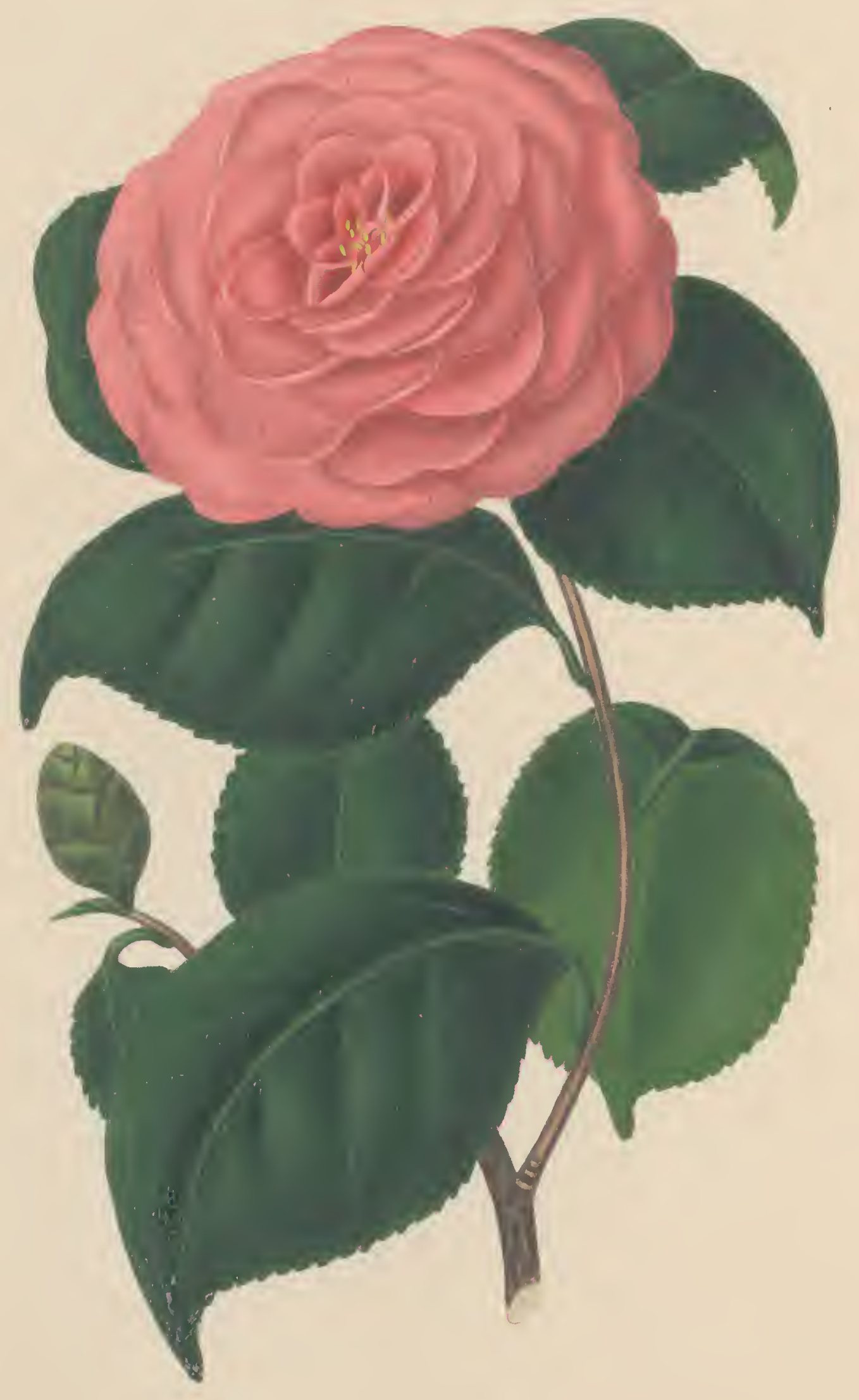

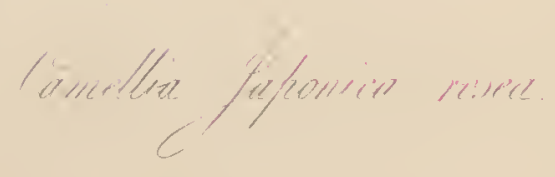



29.

\title{
CAMELLIA JAPONICA ROSEA.
}

Middlemist's Red Camellia.

\author{
Camellia Japonica Carnea. Loddiges's Botanical Cabinet, t. 455. Horti- \\ cultural Society's Transactions, Vol. 7. \\ Camellia Japonica Rosacea. Curtis's Monograph, pl. 4. \\ Camellia Japonica var. Rose-coloured. Botanist's Repository, t. 660, f. 1.
}

THIS variety, as stated by Messrs. Loddiges in their Botanical Cabinet above referred to, was formerly cultivated under a multitude of names, such as the Rose, the Pink, the Fawn-coloured, Paony-flowered, \&c. but is now commonly known by the name we have adopted. It is so very like the Semidouble-red, in habit and foliage, as to render it difficult to distinguish them from one another, unless when in flower; they are however perfectly distinct. Both of them are vigorous growing sorts, and soon attain to a large size. When the plants are eight or ten years old, they flower freely, but in a young state the flowers are sparingly produced.

The branches grow nearly erect, and are of a pale brown colour. The leaves are comparatively round, convex and ovate, broad at the base, and much recurved at the point and edges. The serratures are rather deep and sharp.

The colour of the leaves is a dark shining green, with a peculiar palish hue, which, together with their convexity, gives them a character by which they may easily be recognised. The footstalks are of a dull green, and seldom exceed half an inch in length.

The flower buds are nearly round, and of a dull pale green, covered with several roundish slightly pubescent scales, which, like those of some of the other varieties we have described, are liable to become brown at the edges. This, however, we have reason to think, may be attributed to the plants being generally kept in too high a temperature.

The flowers are late in opening, most of them being in perfection 
about the same time as the Waratáh. They are of a rich rose colour, similar to the Semidouble-red, but are larger, usually measuring three inches or more in expansion. The outer petals are roundish cordate, and upwards of an inch in diameter; before the flower opens fully, they are concave, and arranged regularly in circles over one another. They are not numerous, although the flower may always be said to be more than semidouble. The centre petals are short, and vary in their form; generally they are roundish, and a little twisted, as well as marked with darkcoloured veins ; and all of them, more or less, have a small white stripe in the centre. The stamina are at times perfect, but it is oftener the case that they are transformed into small petals, so that the flower altogether resembles a full-blown rose.

In the Botanical Register, folio 22, it is improperly referred to as the Pæony-flowered, a variety which was not introduced until the present one was common in the Nurseries about London. The period of its introduction to the Kew Garden, is stated in the Botanist's Repository to have been 1808. In the list inserted, on the authority of the late Mr. Lee, of Hammersmith, at the end of Mr. Curtis's splendid Monograph, it is stated not to have been introduced until 1810; but the original introducer of it, Mr. Middlemist, Nurseryman, at Shepherd's Bush, informs us that he brought it home for the Kew Garden in 1804. Unfortunately, by some mistake, it is printed 1808, in our account of this variety in the Horticultural Transactions. 


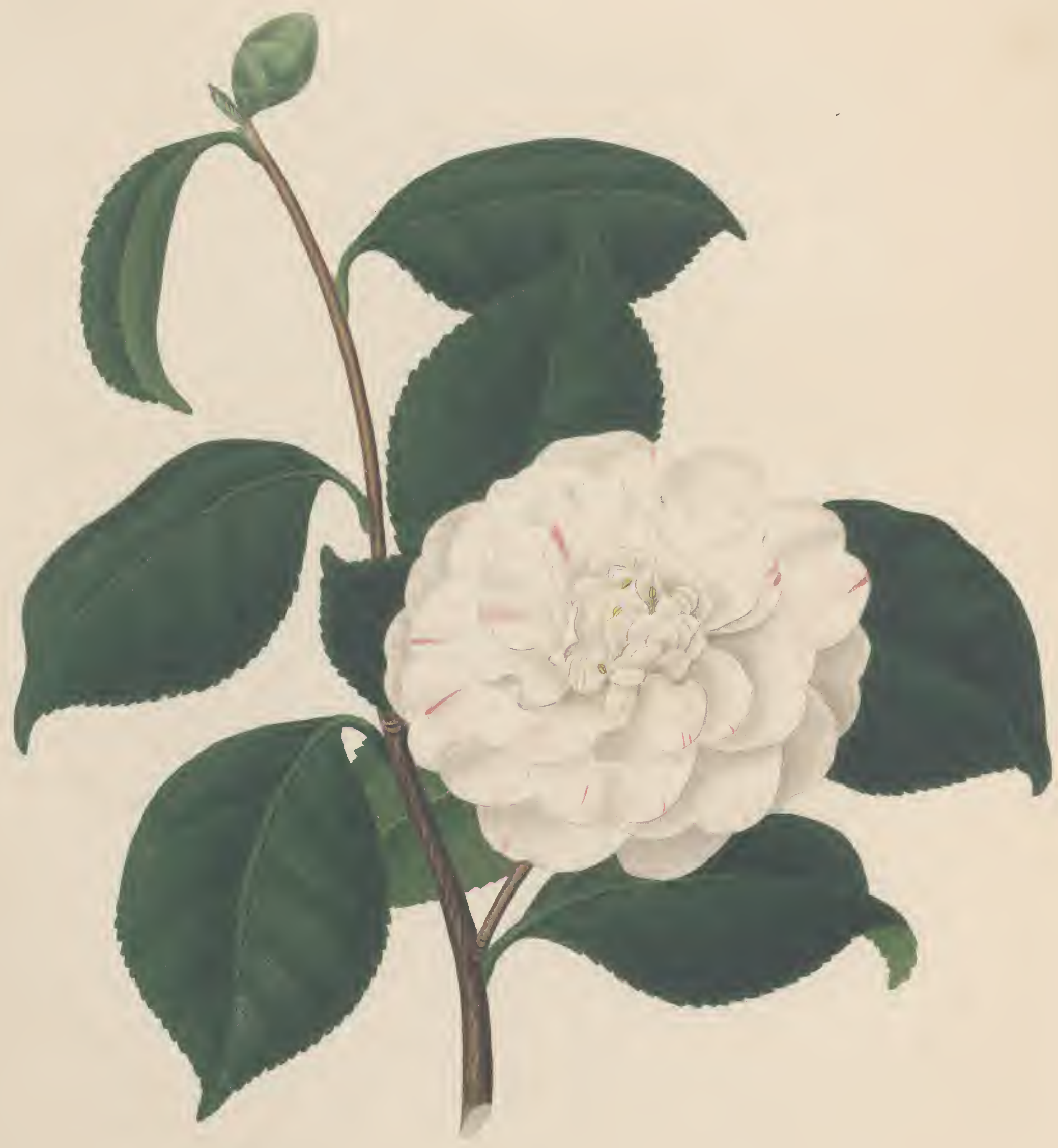



30 .

\section{CAMEELIA JAPONICA ECLIPSIS.}

Press's Eclipse Camellia.

WE owe this choice variety to Mr. Press, who informed us, in March, 1827, when we first saw it in flower, that it was raised by him from a seed contained in the same capsule as that which produced the beautiful variety represented at folio 24 . Both of them are free-growing sorts, resembling the Single-white, but they differ from it, in their foliage being comparatively narrower, and flatter, and not so deeply serrated. That of the one now before us is about the same size, and similar in every respect to Punctata already described.

The flower buds are large and round, very pubescent, of a pale yellowish green colour, spotted with red.

The flowers are handsome and well formed, the petals being numerous, and laid over one another with great regularity. They seldom exceed three inches in diameter. Their ground colour is white, otherwise they resemble Punctata, and Rosa Mundi, two fine seedlings raised also by Mr. Press; being similarly striped, and spotted with pale red, in the manner of what is termed a run carnation. A short account of them will be found in the Gardener's Magazine, vol. ii. p. 358, where they are stated to have a clear white ground, with pink stripes, and to be superior in the beauty of their form to the Double-white. We cannot, however, go quite so far as this, as we consider the flowers of the latter variety are not surpassed by any in cultivation. For the specimen from which the accompanying figure was made, we are indebted to $\mathrm{Mr}$. John Andrew Henderson, F. H. S. Nurseryman, Pine-apple Place, Edgeware Road. 




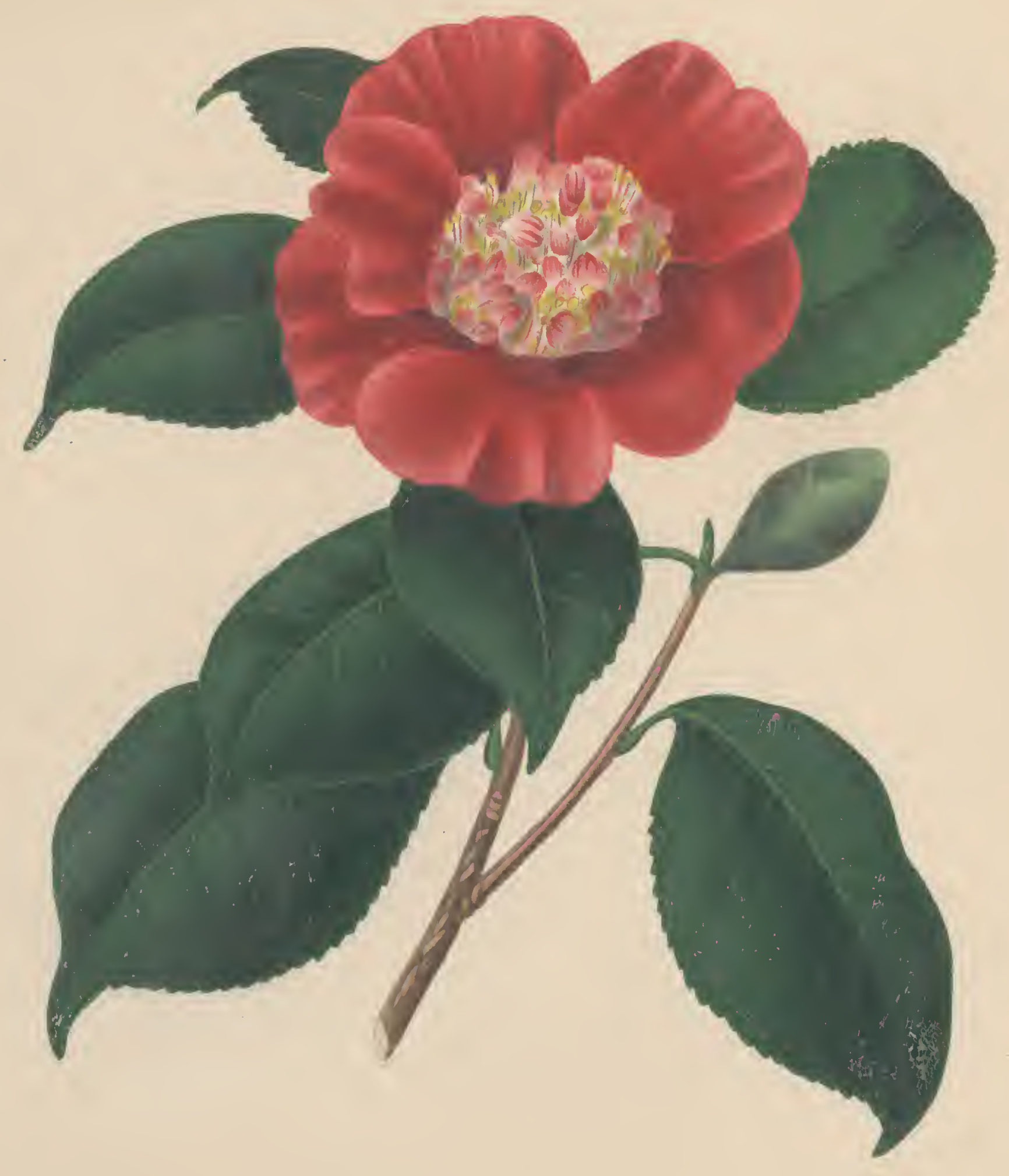

H, 



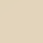


31.

\title{
CAMELLIA JAPONICA INSIGNIS.
}

\author{
Mr. Chandler's Splendid Camellia.
}

Camellia Japonica Insignis. Camellia Britannica, pl. 6.

THIS is a favourite variety with most cultivators, and there are now few collections in which it does not hold a conspicuous place. It was raised by Messrs. Chandler, at the Vauxhall Nursery, about eleven years ago; but it is not more than six years since it began to be generally cultivated. It is of robust growth, and flowers very freely. The habit of the plant shews it to have been raised from the Waratáh, to which it has a great resemblance in the size, form, and dark green colour of its leaves; but they differ in being flatter, and less revolute at the point and edges. The serratures are likewise larger and deeper than in the Waratáh, and the midrib appears to be of a paler colour, and more prominent. In other respects, the leaves of the two plants seem the same.

The flower buds are about an inch long, and not so much pointed as those of the Waratáh. They are generally of a roundish-oval form, and a pale silvery green, seldom coloured, unless perhaps a little at the edge of the scales.

The flowers, by some, are considered to surpass those of its parent; but, in our opinion, they are neither so perfectly double, nor so shewy. They are at first bell-shaped, like the single-red Camellia; by degrees the large outer petals, which are usually seven or eight in number, unfold and exhibit a dense globular mass of small wedge-shaped petals, more or less variegated with red and white, like a carnation, and incurved towards the styles, which rise conspicuous in the centre. When the outer petals are expanded, the flowers measure about three inches across. The petals themselves exceed an inch in diameter; at the apex they are indented, but otherwise they are flat, and round, and of a deep rose colour, indistinctly marked with darker coloured veins. The inner petals are very small, and ranged over one another, like those of the Waratáh. In the 
centre of the flower, it is common for many of them to be but partly transformed, one half of the anther being dilated and coloured, while the other half appears almost perfect, and of a deep yellow colour. Similar instances of this curious metamorphosis are met with in the flowers of other Camellias we have described. They present a striking illustration of the generally received opinion, that stamens change into petals, instead of petals changing into stamens, \&c. :-a theory some years ago advanced by Professor Lindley, in an ingenious paper communicated by him to the Horticultural Society, and printed in the sixth volume of their Transactions.

We may here notice a variety which corresponds, almost in every respect, with the one we have just described. It was raised by Mr. Knight, of the King's Road, Chelsea, and is commonly known by the name of Knight's Carnation Waratáh. A figure of it will be found in Loddiges's Botanical Cabinet, fol. 1463, under the name of Camellia Japonica Knightii. It is the variety of No. 19, dianthiflora, of Loudon's Hortus Britannicus, a work of great merit, and one of the most complete of its kind which has ever appeared. 



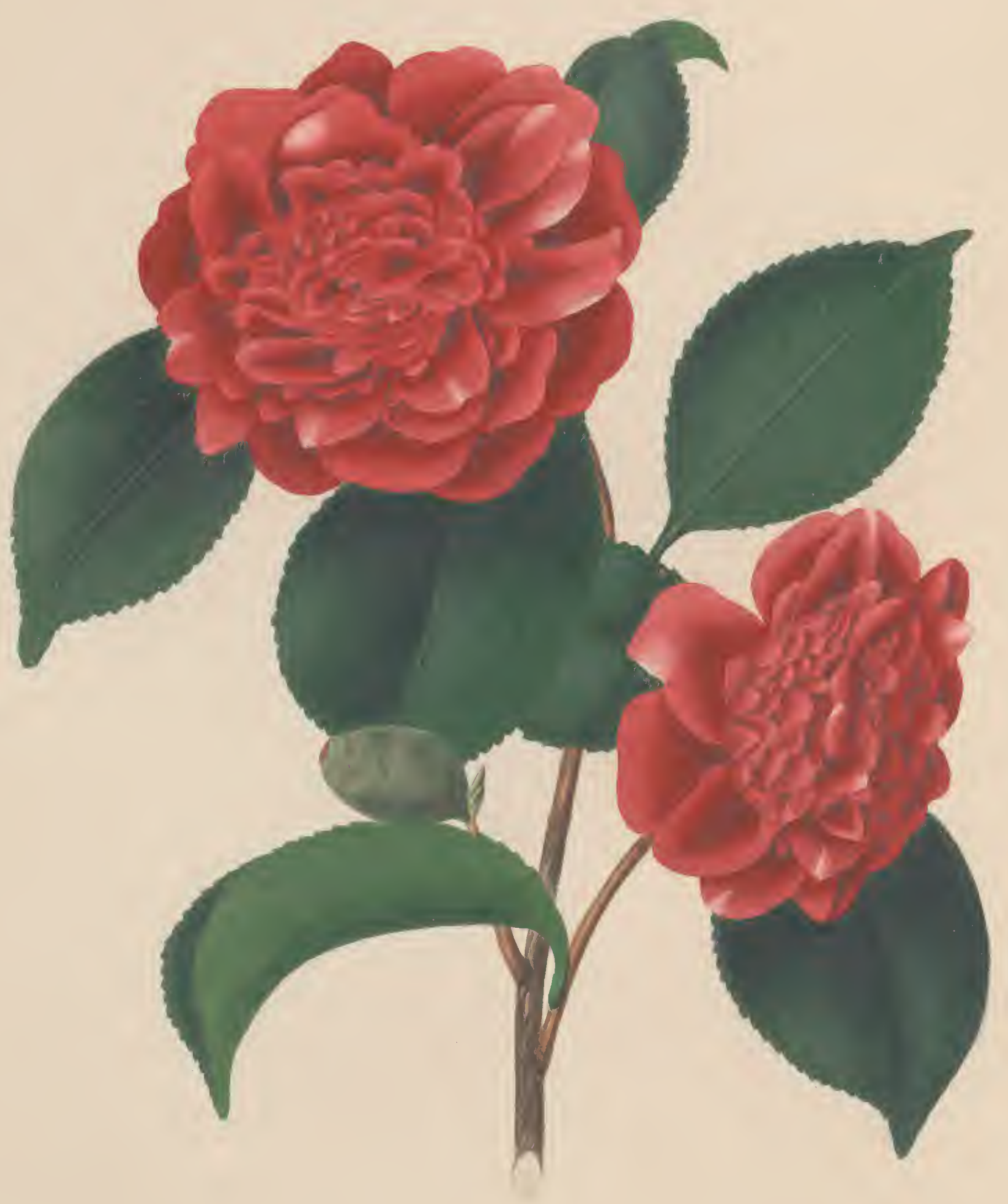




32.

\title{
CAMELLIA JAPONICA SPECIOSA.
}

\author{
Rawes's Variegated Waratáh Camellia.
}

\section{Camellia Japonica speciosa. Horticultural Transactions, Vol. 7. \\ Camellia Rawesiana of the Gardens.}

WE first noticed this splendid variety in March 1826, in the choice collection of Thomas Carey Palmer, Esq. at Bromley in Kent, to whom a plant of it was presented, by his relation, Captain Richard Rawes, on its first importation by him, in 1824 .

In general appearance, it is very distinct from any of the other imported varieties, and, like them, may at once be distinguished by the leaves, which are comparatively thin, and of a bright vivid green. They are for the most part nearly flat and ovate, broad at the base, and somewhat narrower towards the point; sometimes a few of them are slightly recurved. The serratures are shallow, small, and sharp, becoming indistinct near the base of the leaf. The midrib and veins are of a palish green, not very prominent, nor so strong as in some of the other kinds; the usual size of the leaves is about three and a half inches long, and two and a half inches broad. The footstalks are roundish and slightly hollowed on the upper side, generally half an inch long, and of the same colour as the midrib and veins.

Flower buds oval, with a blunt point; the scales are dull green, roundish cordate, slightly pubescent, and at the edges, which are thin, frequently have a brownish tinge.

The flower's are exceedingly handsome, and of a deeper red than either Atro-rubens, or Waratáh, but approach in some degree those of the latter. They open very regularly, and, when expanded, are usually four inches in diameter. The outer petals vary from an inch, to an inch and a half in breadth, and are sometimes slightly cordate, but most generally rounded at the edges, a little recurved, and faintly veined. 
These large outer petals are from ten to twelve, or more, in number, placed in two or three rows rather irregularly over one another, with a few unequal blotches of white appearing on some of them, near the edges; above these there is a set of small incurved petals, like those of the Waratáh, nearly an inch in thickness, which rise almost upright, and increase in size the nearer they approach the centre. A third set, consisting of eight or ten large petals like the exterior ones, but more concave and erect, overtops the last, and surrounds another set of small incurved petals; so that altogether they present the anomalous appearance of two flowers, one of which is formed in the centre of the other. It is proper to remark, that nearly the whole of the petals have a little white stripe at the base, and some of them are even variegated up the centre; they are likewise tipped with white, in a similar manner to the petals of the Waratáh.

With the exception of two plants sent to the Horticultural Society, in 1828, by Mr. John Reeves, Esq. of Canton, which have every appearance of being the same as this, although they have not yet flowered, we believe the whole that are at present in the country have been derived from Mr. Palmer's plant. To that gentleman we are indebted for the opportunity of giving a figure of it, as well as to John Allnutt, Esq. F. H. S. of Clapham Common, who possesses a good collection, which he cultivates very successfully. 


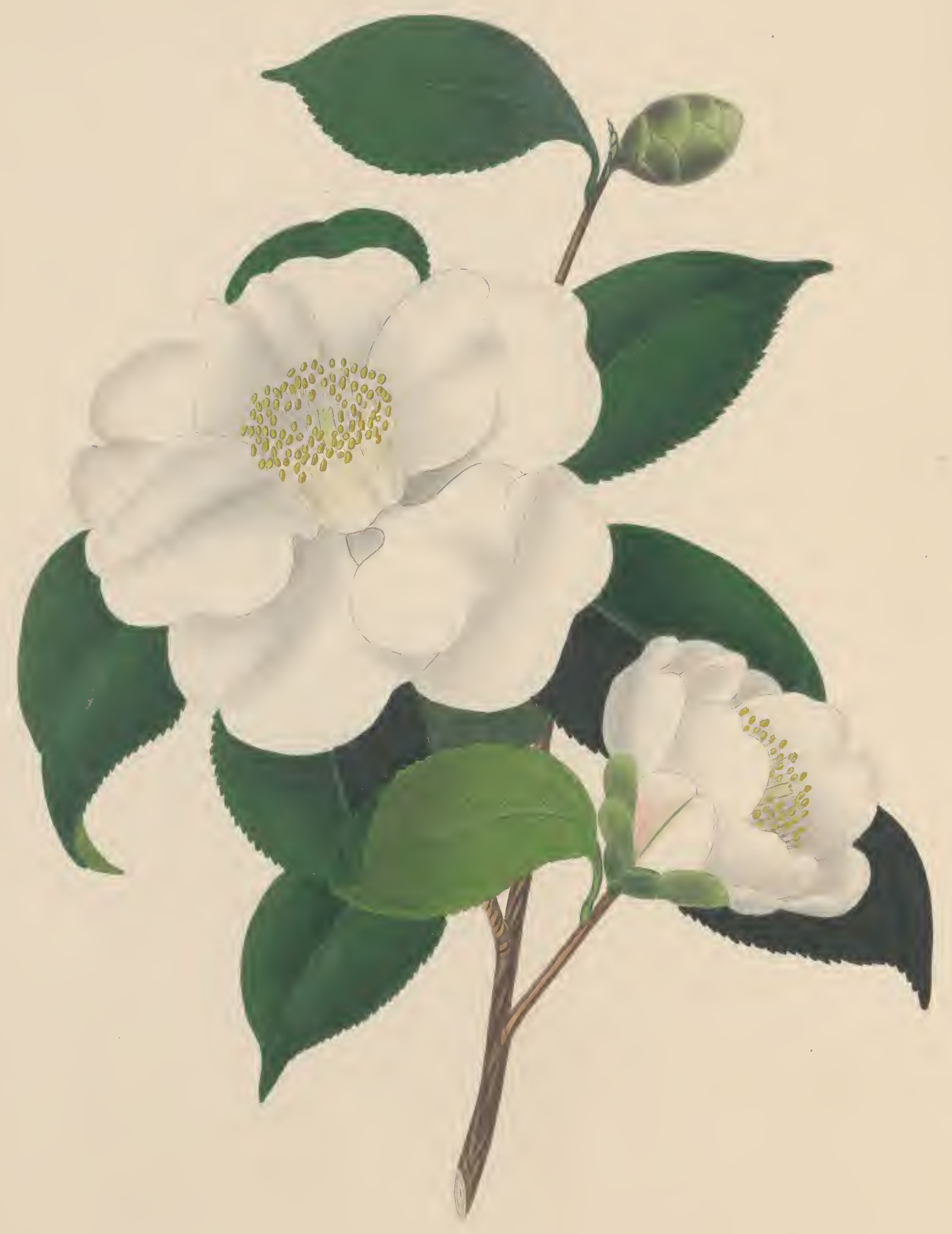

Cameltua Fapunea atira semiduplex 

33.

\section{CAMELLIA JAPONICA ALBA SEMIDUPLEX.}

\section{Mr. Palmer's Semi-double White Camellia.}

WHEN we prepared the account of the Chinese Camellias in this country for the Horticultural Society, the variety now before us was but imperfectly known, and even at the present time its history is rather involved in obscurity. We are indebted for its introduction to $\mathrm{Mr}$. Palmer of Bromley, who informed us that he purchased his plant at a Garden on the Continent, in 1822. (?) How, or by whom, it was carried to the Continent, we have not been able to ascertain ; but from inquiries made by Mr. Sabine, when Secretary of the Horticultural Society, we have learned, through a letter to him, from John Reeves, Esq. dated Canton, Feb. 1st, 1826, that Mr. Ball was the first who sent a plant of it to England, from whence it was forwarded by some means to Rouen, together with the $Y_{o k} Y e e p$, the plant which produces the bamboo-like leaves which envelope the green tea chests. From this source it is probable Mr. Palmer's plant originated.

In habit and foliage it has much resemblance to the Pompone and Pæony-flowered varieties; being of slender growth, with upright palecoloured branches, sparingly furnished with dark green, oval, pointed leaves, about the size of those of the Pompone, and similarly recurved at the edges. They are likewise sharply serrated, and have a conspicuous pale-coloured midrib. The footstalks appear to be rather thicker and shorter than in the varieties just referred to, but in other respects we think them the same.

The flower buds are peculiar, being long and pointed, like the buds of the Single Red, but of a paler green colour, and more pubescent.

The flowers consist of about eight or nine roundish white petals, ranged in two rows, or even three rows, when they happen to be more numerous than we have stated; and average rather more than four inches in expansion. They are at first bell-shaped, but in the course of a few 
days the petals gradually open and spread nearly flat, as well as the cup, or column, of stamina, which is comparatively short, and divided into separate parcels. The largest petals are round, and about an inch and a half in diameter; the others are roundish oblong, and a little smaller. All of them are extremely delicate, like those of Welbank's White, represented at folio 27 .

The accompanying figure was made, by permission of Mr. Palmer, from a plant which flowered in his Conservatory in March last. 



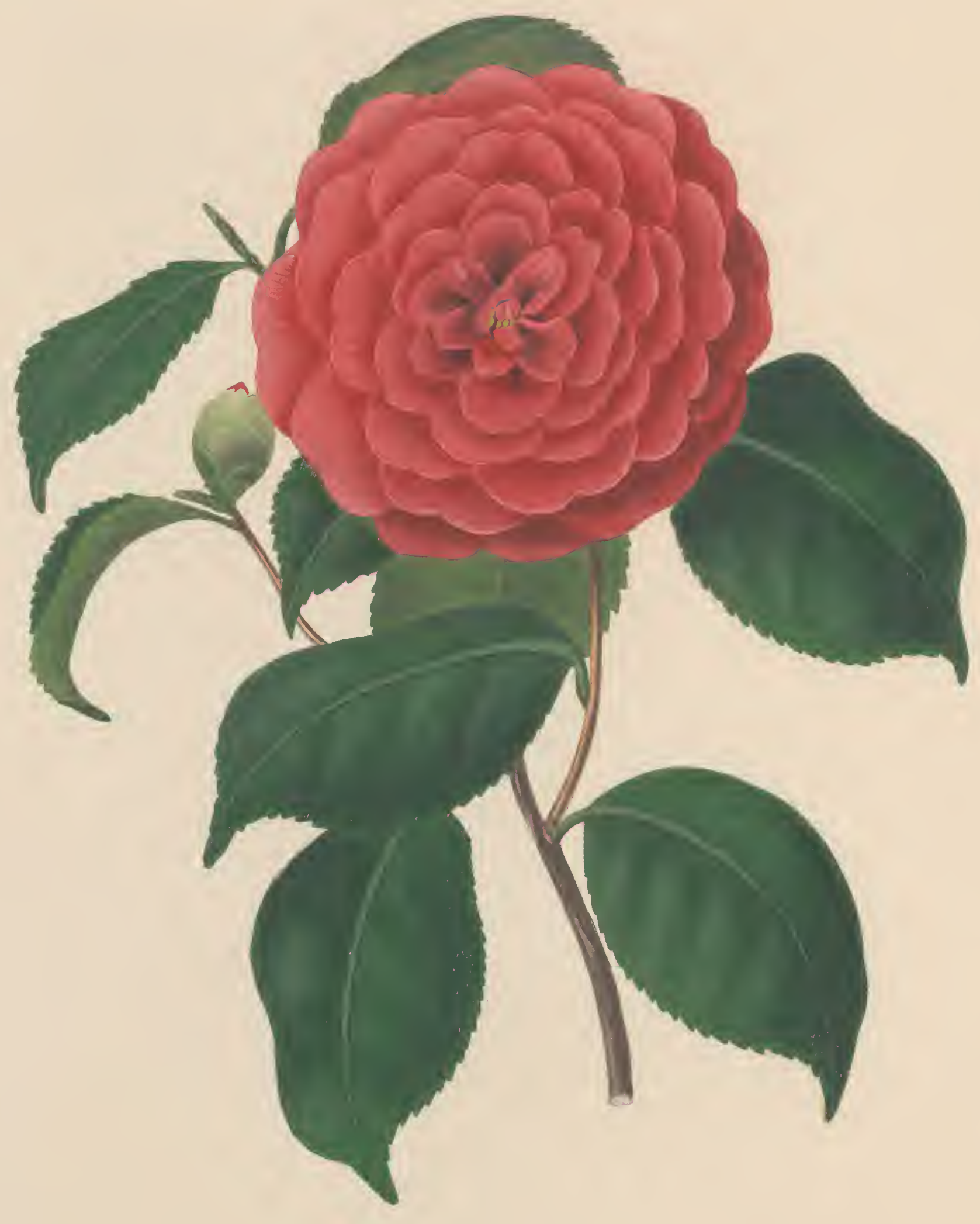

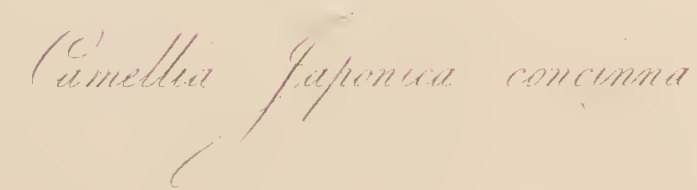




34.

CAMELLIA JAPONICA CONCINNA.

Chandler's Elegant Camellia.

THE first plant of this variety which flowered, we recollect to have seen exhibited at the meeting of the Horticultural Society, on the 17 th of April, 1827. It was raised at the Vauxhall Nursery, by Messis. Chandler, in 1819, from seed of the Waratáh, and possesses much beauty, although its flowers are not so brilliant as some we have represented. At present we believe it is little known, and in few collections; but in a short time hence, we hope to see it generally cultivated.

Its habit is rather peculiar, the branches being deeply coloured, and clothed with foliage somewhat resembling the Single Red, but smaller, and flatter, with a sharper and more recurved point, and with the round slender footstalk which characterises the Waratàh.

The flower buds are roundish oval, pale yellowish green, with the scales slightly tinged with brown at the edges, and very pubescent.

The flowers are of a fine rose colour, very regularly formed, and open well. When fully expanded, they measure rather more than three inches in diameter, and are little inferior in appearance to the flowers of Eximia, represented at folio 12, or Imbricata, at folio 22 , the petals being nearly as numerous, and arranged with equal nicety over one another, from the circumference to the centre. The exterior petals are at first concave, but by degrees spread almost flat. They are each of a roundish form, and about an inch in diameter. The interior ones are small and pointed, and rise erect, as in the flowers of the two varieties above mentioned, to which the one now before us, has considerable resemblance. We shall, however, briefly state the most obvious characters by which each of them may be distinguished. In Eximia, the 
petals are large, roundish concave, and notched; in Imbricata, they are nearly round, concave, and entire; and in Concinna, our present subject, they are for the most part nearly round and flat. The colour of each is also different, as well as the foliage, which of itself is sufficient to prevent their being confounded. 



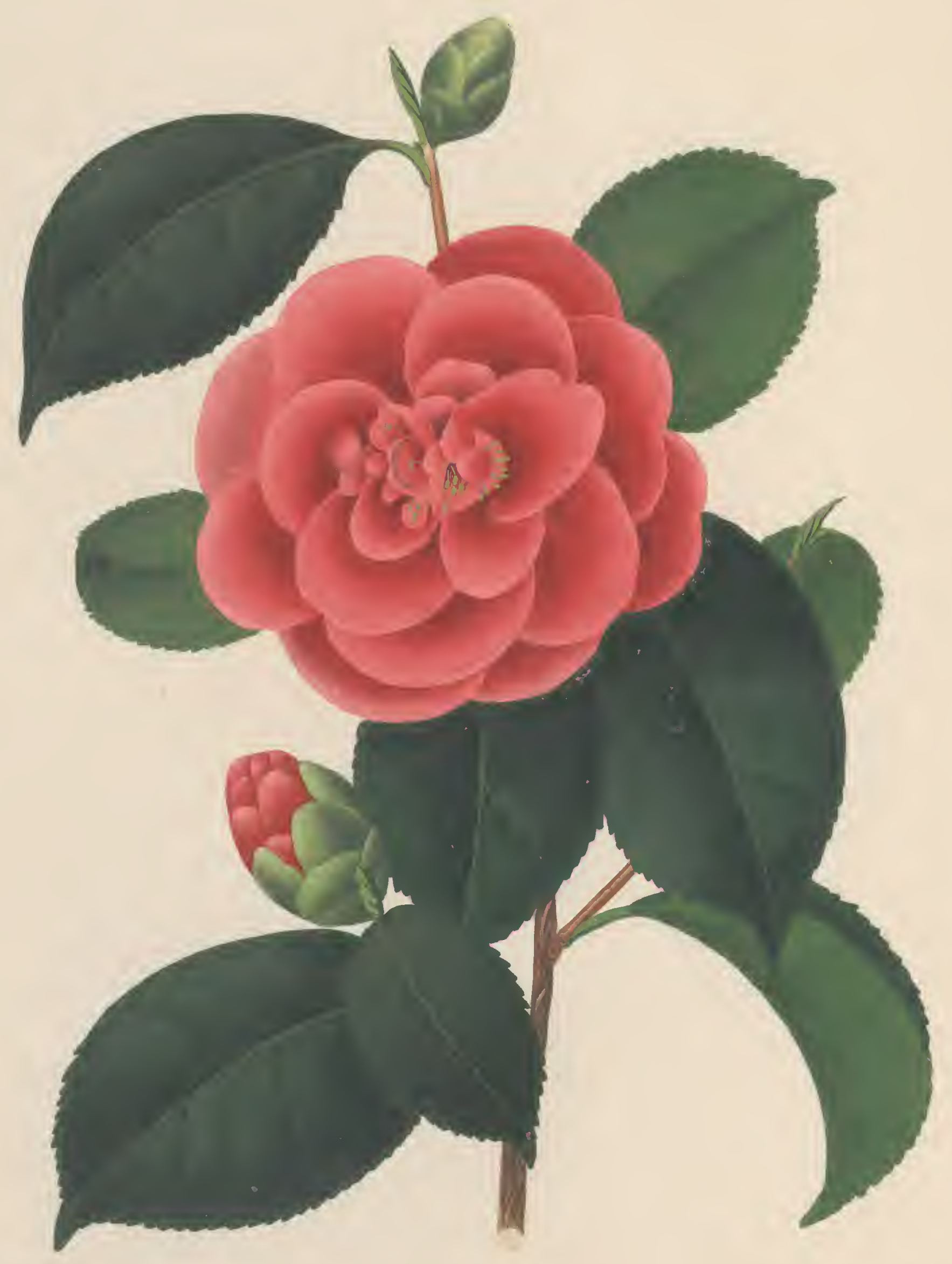

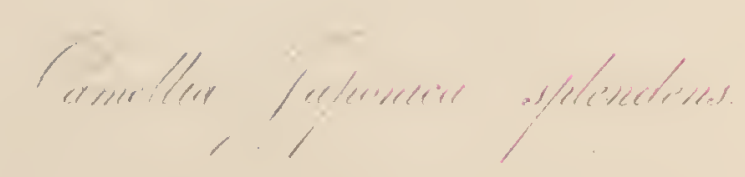



35.

CAMELLIA JAPONICA SPLENDENS.

Mr. Allnutt's Splendid Camellia.

Camellia Japonica Coccinea. Loddiges's Botanical Cabinet, t.1231. Loudon's Hortus Britannicus, p. 293. No. 28.

THIS much-admired variety was raised many years ago, by John Allnutt, Esq. of Clapham Common, in whose garden the original plant has attained a large size, and is now growing very luxuriantly. We believe it is one of the first Camellias that was obtained from seed in this country.

The habit of the plant is similar to that of the Single Red, but it seems to be rather stronger, and more bushy. The branches are upright, round, and twiggy, and of a deep brown colour.

The leaves are comparatively thin and narrow, much recurved at the point and edges, which are sharply and rather deeply serrated. Their usual size is about three inches and a half long, and two inches broad near the base, from which they taper gradually towards the point. Their colour is a rich deep green, with a prominent pale-coloured midrib and footstalk; the latter, which is nearly round, seldom exceeds half an inch in length.

The flower buds are moderately long and pointed, of a deep green until near expansion, when they become paler, and occasionally tinged with deep red. The scales are pointed and thin, but less pubescent than those of the other varieties we have described.

The flowers are particularly shewy, and produced in great abundance upon young plants, as well as old ones, which renders it a most desirable variety for every collection. They are of a brilliant red colour, and measure about three inches in expansion. The petals are not very numerous, but from the manner in which they are arranged in the centre, they cause the flowers to have the appearance of being perfectly 
double. The outer ones are slightly concave, and upwards of an inch in diameter. The inner are similar to the others, but proportionally smaller. All of them are deeply veined, and so remarkable for their roundness, as to give the flowers a peculiar character, by which the variety may be readily distinguished.

It is figured in Loddiges's Botanical Cabinet, under the name of Coccinea. We have adopted the one given to it by Mr. Allnutt, as being the name by which it is most generally known in collections about London. 



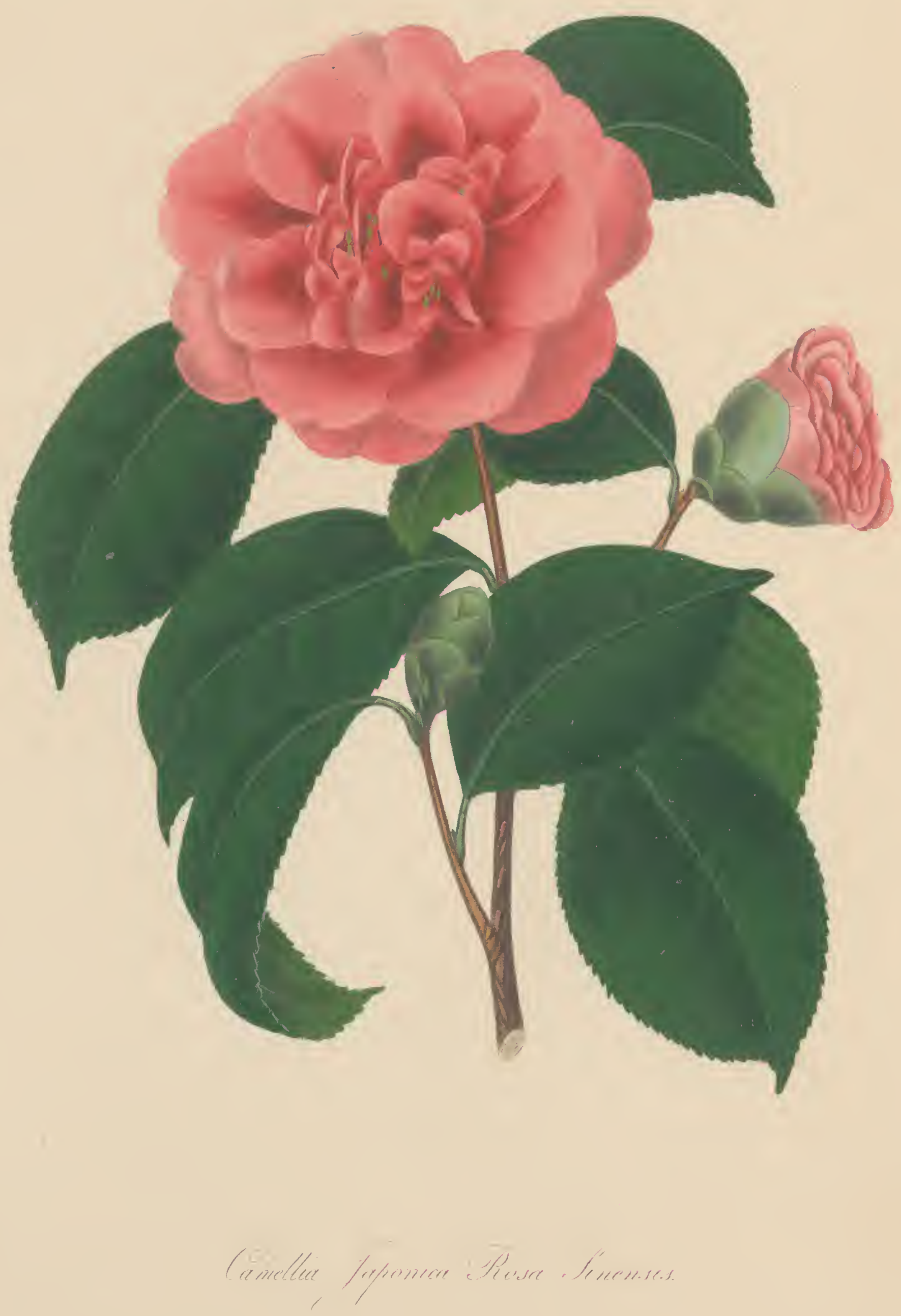




36.

CAMELLIA JAPONICA ROSA-SINENSIS.

China Rose Camellia.

Camellia Japonica Rosa-sinensis. Loddiges's Botanical Cabinet, t. 1455.

OUR present subject, which is unquestionably one of first-rate excellence, was raised by Mr. Chandler, about the year 1819. It is described in the work we have just quoted, as being a bold-flowering variety, apparently blooming freely, and, in even the present state of extended cultivation of these splendid plants, may be considered as sufficiently distinct to merit a place in any green-house.

The branches are numerous, and grow very compact and erect. The leaves are of a deep shining green colour, moderately large, roundish oval, much pointed, and sharply serrated. They usually measure about three inches in length, and rather more than an inch and a half in breadth. The midrib and veins are strong and prominent on the upper side, and of a pale yellowish green; beneath, they are less conspicuous, and of a duller colour. The footstalks are almost round, excepting the upper side, which is a little flattened. They are about half an inch in length, and of a dull green colour, like the veins and midrib.

The flower buds are large, roundish oval, and blunt at the point. The scales are also large, of a pale yellowish green colour, not very pubescent.

The flowers are extremely handsome, a good deal resembling those of Elegans, represented at folio 26, in the size and arrangement of the petals. Their colour is also similar, but when compared together, the difference is obvious and striking. That of the one now before us is more of a pale purplish red than the other, and not quite so bright. When fully open, they measure no less than four inches in expansion. The outer petals are large, flat, and spreading. The inner ones are 
small and irregularly formed; sometimes they are rolled inwards, and much twisted, with a few imperfect stamens intermixed among them. The size of the outer petals is remarkable, many of them being about an inch and a half in diameter, and some will be found even larger. They are very prettily marked with dark-coloured veins, and altogether form as elegant a flower as any which we have yet represented. 



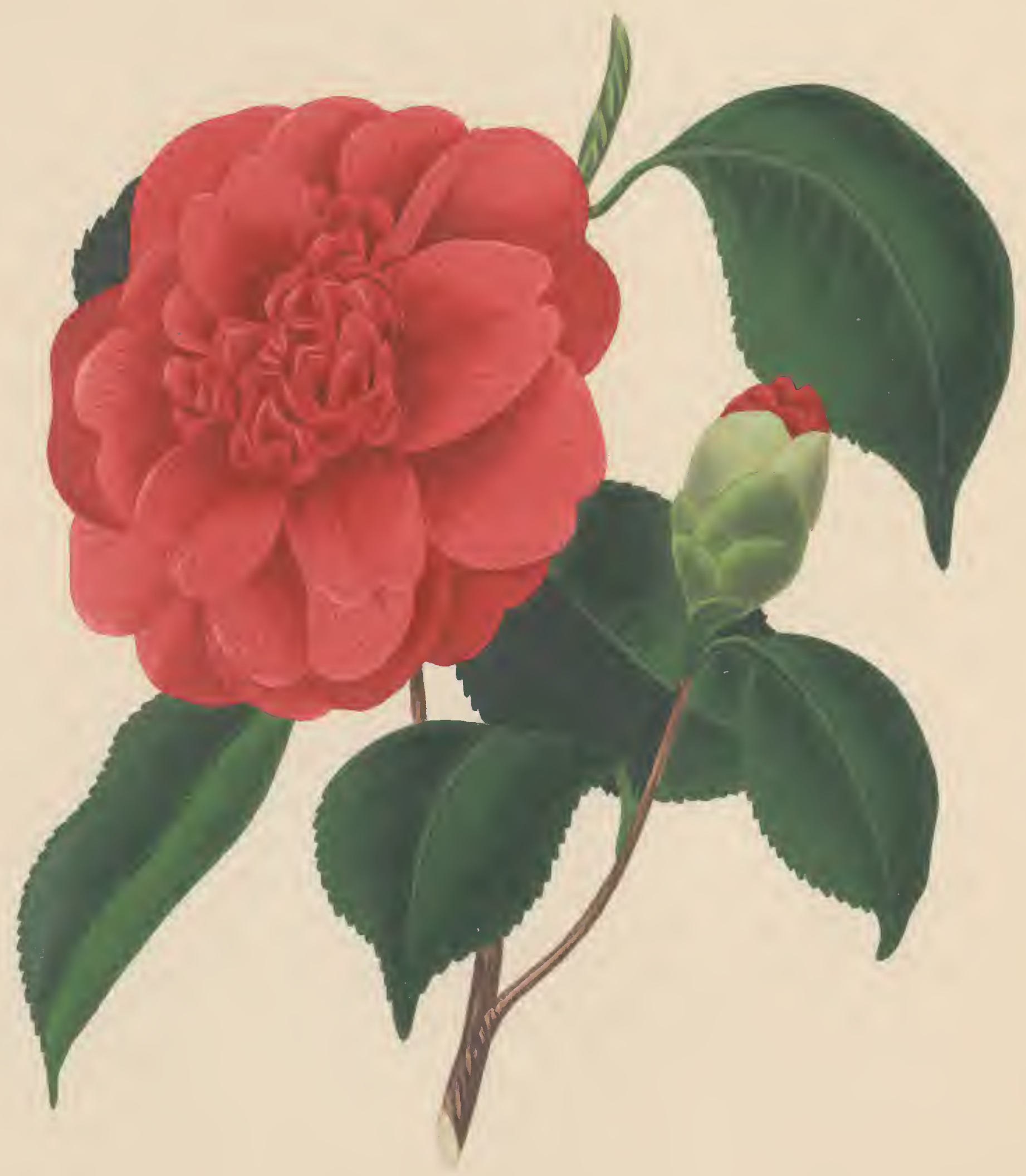

Cameltex faponece iPofor 

37.

\title{
CAMELLIA JAPONICA ROSSII.
}

\author{
Mr. Ross's Camellia.
}

Camellia Japonica Rossii. Loddiges's Botanical Cabinet, t. 1737. Loudon's Hortus Britannicus, p. 293. No. 33.

THIS desirable variety was named in honour of the late Mr. William Ross, F.L.S. and H.S., a respectable Nurseryman at Stoke Newington, of whom a brief memoir will be found in the Gardener's Magazine, vol. i, p. 95, and a notice of his Camellia in the same volume, p. 211, under the name of Ross's Camellia Gloriosa.

It is a free growing sort, with remarkably large dark green leaves, coarsely but not deeply serrated, resembling, in many respects, the foliage of Corallina, figured at folio 10. The footstalks are similar to those of its parent, the Waratah; round and slender, and of a pale brownish green.

The flower buds are large, oval, and pointed; of a deep green, until near expansion, when they become paler, and very long.

The flowers are generally very large and shewy, often measuring four inches in diameter. They have a considerable resemblance in their form to those of Elegans, represented at folio 26; but in colour they are of a much deeper, and darker red. All the petals are faintly veined; the outer ones, which expand nearly flat, are from twelve to seventeen in number, arranged in two or three distinct rows round the smaller ones which occupy the centre. The former are each roundishoblong, about an inch broad, and deeply indented at the extremity. The inner petals are seldom more than one-third the length of the others, and are similar to those of the Waratáh, being narrow, pointed, and incurved, but ranged with less regularity. 
We believe this was one of the first seedling Camellias exhibited to the Horticultural Society. It was then, in March 1824, as well as we recollect, considered so great a novelty, that a medal was awarded to Mr. Ross, for his success in raising it. 



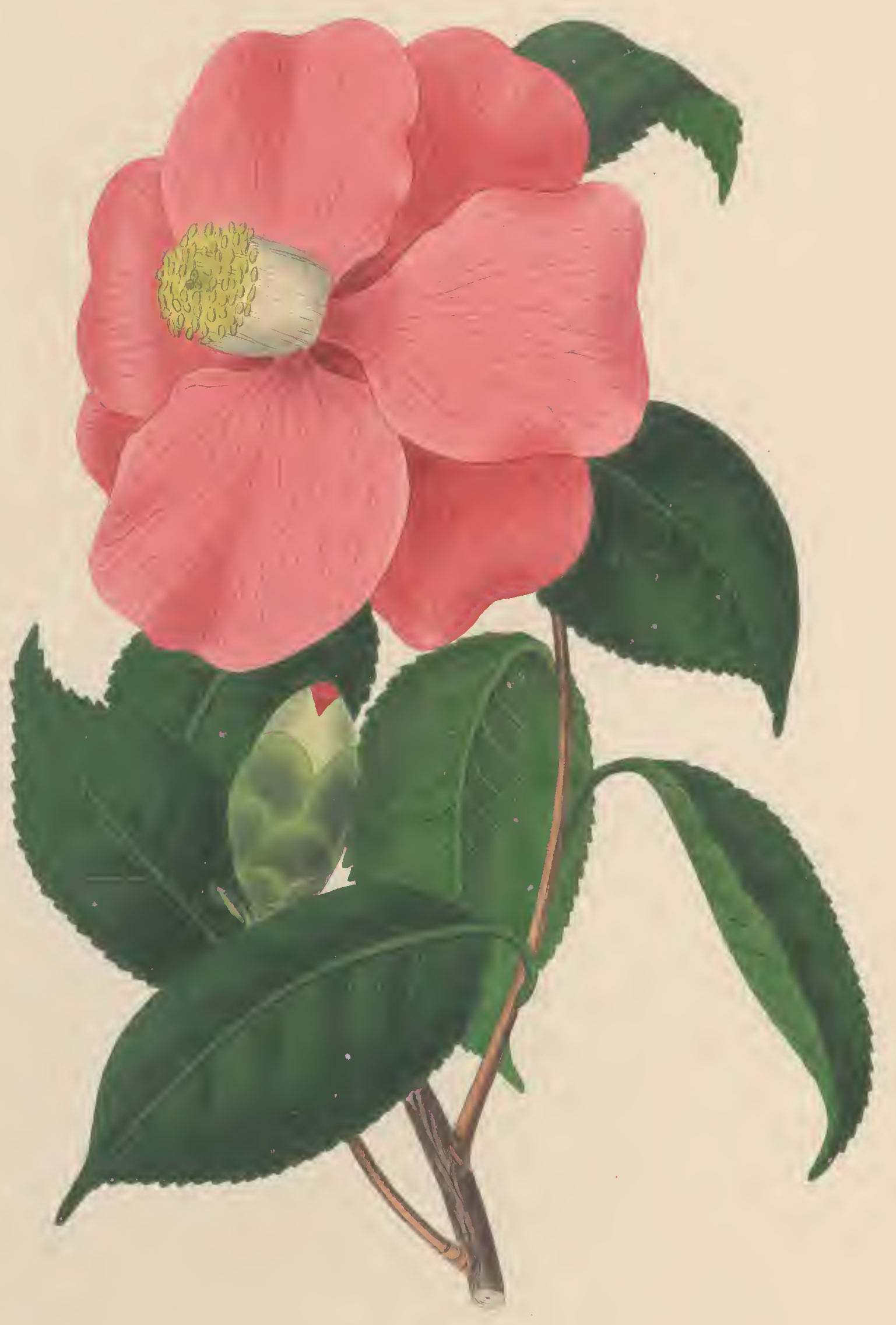

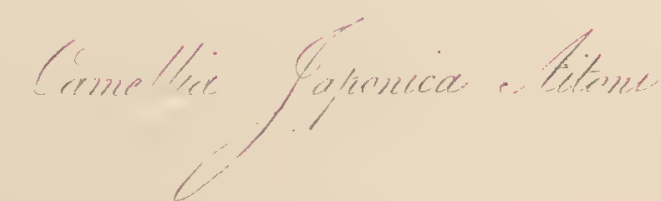




38.

\section{CAMELLIA JAPONICA AITONI.}

Mr. Aiton's Camellia.

Camellia Japonica Aitonia. Chandler's Camellia Britannica, pl. 3. Loudon's Hortus Britannicus, p. 293. No. 36.

FROM the Work we have just referred to, we learn that this Camellia, and four others, were raised at the Vauxhall Nursery, from seeds contained in a capsule of the Pompone, sown in November, 1819; and that it was named in compliment to William Townsend Aiton, Esq. of the Royal Gardens, Kew. It is, unquestionably, a very striking variety, and a most valuable one to the Camellia grower, on account of its producing seed more freely than any other kind whatever. In habit and general character it seems to resemble the Pompone; but the branches are upon the whole more vigorous, and the leaves flatter and more pointed.

The flower buds are very large before expansion, and of a deep silvery green colour. They are at first a good deal pointed, but gradually become blunt, and almost round.

The flower consists of only five or six large roundish, or roundishcordate petals, each averaging from an inch and a half to two inches in diameter. They are faintly veined, and of a bright rose colour, measuring between three and four inches across, when fully expanded. Like the other Single Camellias, they are at first bell-shaped, the petals being closely imbricated at the base, and surrounding the cup or column of stamina, which rises conspicuously in the centre; by degrees they spread open, until at last they become almost flat. The filaments are moderately strong, and of a delicate yellow colour. The anthers are remarkably large, and of a deep yellow. 




$$
5
$$



39.

CAMELLIA JAPONICA CRASSINERVIS.

\author{
Mr. Kent's Camellia. \\ Camellia Japonica Crassinervis. Loddiges's Botanical Cabinet, t. 1475. \\ Transactions of Hort. Soc. vol. 7. Loudon's Hortus Britannicus, \\ p. 293. No. 22.
}

THIS beautiful variety is believed to have been imported by Captain Rawes, about the year 1820, and to have flowered first in this country in the collection of William Kent, Esq. when at Clapton.

It is so extremely like the Waratáh, represented at folio 8 , in its flowers, as to render a minute description of them unnecessary. The only difference appears to be that, in the flowers of the variety now before us, the outer petals are more cupped, and paler in colour than those of the Waratáh. The habit and foliage of the two sorts are, however, perfectly distinct; so that, when not in flower, they may easily be distinguished from one another. The present is of free growth, peculiarly stiff and erect, with pale-coloured branches. The leaves, which are nearly flat, are comparatively thinner and rounder than those of the Waratáh; they are also more veiny on the upper side, as well as more sharply serrated, and have short, slightly-flattened (not round) and slender footstalks. In colour and other respects the two sorts appear the same.

An excellent figure is given of it in the Botanical Cabinet, above referred to, under the name we have adopted. It is, however, generally cultivated, and known by the name of "Kent's Hexangular," from its having been supposed, on its first introduction, to be the hexangular variety so much esteemed by the Chinese. 




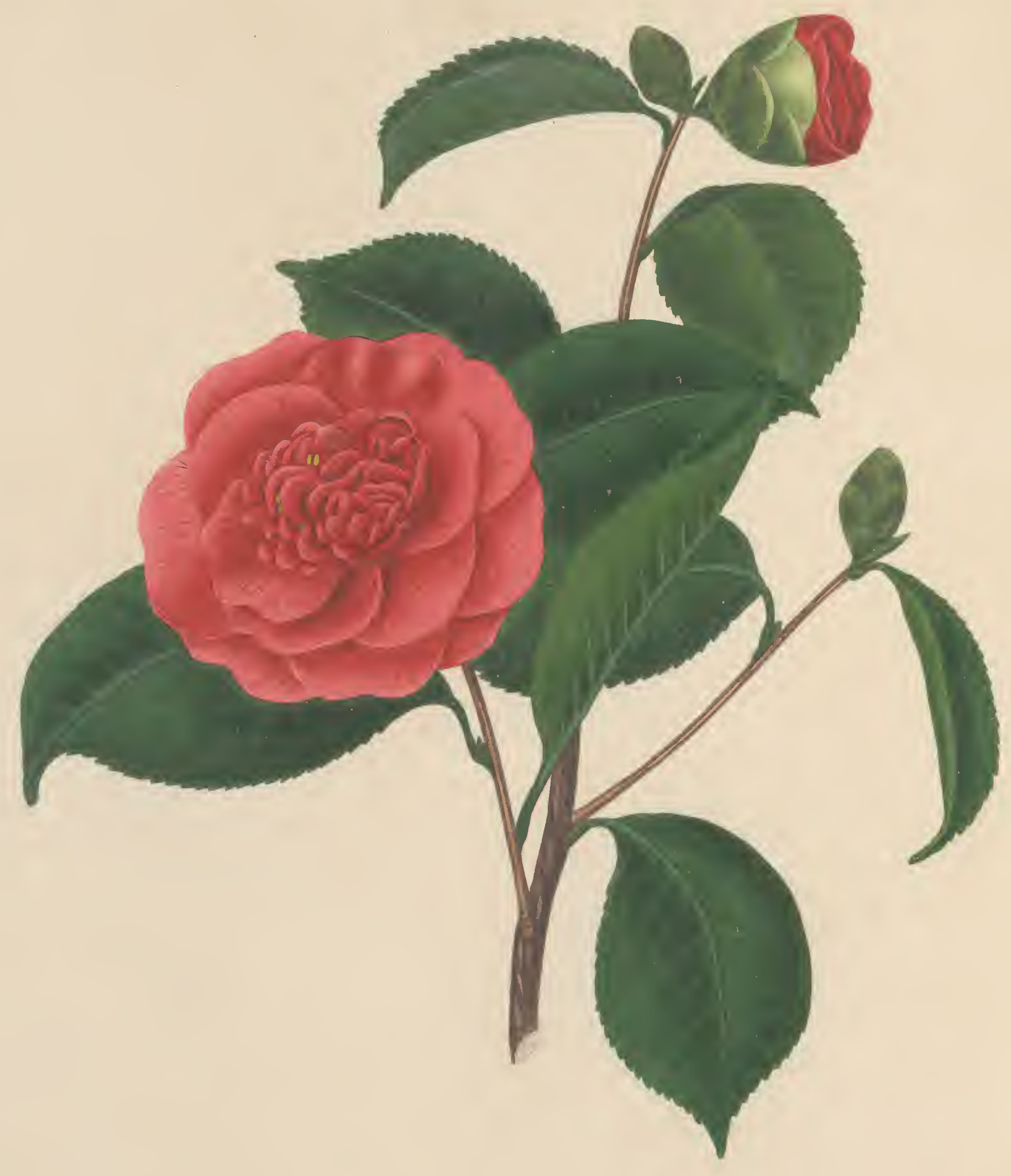

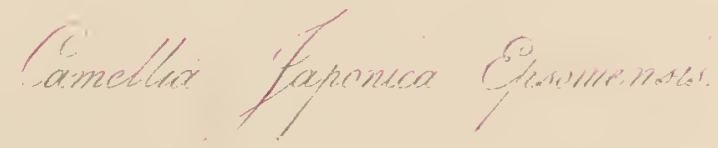




40.

\section{CAMELLIA JAPONICA EPSOMENSIS.}

Mr. Young's Semi-double Red Camellia.

WE first derived our knowledge of this very distinct variety, from seeing a plant of it in the extensive collection of the Horticultural Society; to which establishment it was presented, in 1824, by Mr. Young of Epsom, who has the merit of raising it.

The plant is of a robust liabit, surpassing in this respect most of the seedlings with which we are acquainted. The leaves are roundish oval, flat, and rather veiny on the upper side, with large serratures, and a bluntish recurved point. They generally measure about four inches in length, and three inches in breadth, in the widest part; and are besides remarkable for having a very strong, prominent, palecoloured midrib and footstalk; the latter seldom exceeds an inch in length. The colour of the leaves is a rich, deep shining green.

The flower buds are oval, somewhat pointed and pubescent, of a pale yellowish green, slightly tinged with red before opening.

The flowers are not unlike those of the common Semi-double Red, but they are of a much deeper colour, and consist of a greater number of petals; in this respect, however, they vary very much, some flowers having only ten or twelve petals arranged in two rows, while others on the same plant occasionally have the centre tolerably well filled, and appear almost double. In the former case, the exterior row of petals is large and spreading; each of them is of a roundish form, averaging an inch in diameter. The interior row is of a lesser size, but similar to the other. The cup, or column of stamina, is nearly the same as in the Single Camellias, but is deeply coloured at its base. When the petals happen to be numerous, the flowers have a neat appearance; the cup of 
stamina being then partly transformed into small, roundish, spatulate, striped red petals, all of which, as well as the large outer ones, are pretty evenly arranged over one another, and distinctly marked with darkcoloured veins. The usual colour of the flowers is a deep red, approaching to scarlet. The largest of them scarcely measures more than three inches in diameter. 
PROPAGATION AND CULTURE, \&c.

$\mathrm{O}_{\mathrm{N}}$ this subject much useful information will be found in the third volume of the Memoirs of the Caledonian Horticultural Society, where there is an excellent practical paper, by a distinguished cultivator of Camellias, Mr. Walter Henderson, F.H.S. gardener to Walter Campbell, Esq. M.P. Woodhall, Lanarkshire. The works of Curtis, Sweet, Macintosh, and Loudon, also contain much interesting matter connected with the culture and treatment of Camellias. From these we shall gather what is most important for our present purpose, and add such remarks as have occurred to us in the course of our own practice.

\section{SOIL.}

The soil which we consider best for Camellias, and in which they are grown by those who cultivate them extensively in the neighbourhood of London, is a strong, rich, yellow loam. If it is supposed to be too retentive of moisture, a portion of peat, or bog-earth, and sand, is generally mixed with it; and in this compost the plants grow vigorously. Curtis recommends about one third good bog-earth, and two thirds rich sandy loam; when there is a larger proportion of the former than of the latter in the compost, he says, the plants will make greater shoots, but are shyer in producing blossom.

Henderson's compost is as follows, viz.-One part of light brown mould, one part of river sand, one part of peat earth, one half part rotted leaves; mix them all well together; and when the Camellias require shifting, put some broken coal-char in the bottom of the pots, and some dry moss, or hypnum, over it. Instead of the coal-char being 
put in the pots for drainage, we would recommend broken potsherds, or the rough siftings of the compost.

Messrs. Loddiges formerly used loam, with a little sand and peat, for most of the sorts, but latterly they find light loam alone to answer as well, or better. This shows that Camellias will grow in what is termed a good rich soil. If they are planted in a conservatory, the soil need not be very sandy; but if kept in pots, a moderate proportion of sand is absolutely necessary.

\section{PROPAGATION.}

This is usually performed by the several methods of seeds, layers, inarching or grafting, budding, and cuttings.

By Seeds. - We have given a figure of the ripe capsule and seeds, in plate 1. They are sometimes very freely produced, but more so on certain kinds than on others. The Single-red, Aitoni, and the Waratáh, are the best we know for obtaining seed from. Curtis gives the following directions respecting the raising of Camellias from seed:They should be sown.in large pots, two inches apart. After they have been sown a week or two, and regularly kept moistened, so as to be nearly constantly damp, they should be plunged into a gentle bottom heat, of either tan or dung, until they are up; after which, they may be gradually inured to the air, and the following winter they may be potted separately into small pots, and kept with the other plants until they flower. Should any of them prove handsome, they are of course added to the collection, but if otherwise, they are set aside for stocks to graft on.

By Layers.-For those who are not skilled in grafting, this is by far the best mode of propagating Camellias. It is also a ready way for obtaining good healthy plants of particular varieties, or of such as are cultivated for stocks. The plan which is usually pursued, is as follows: A frame is prepared, and filled with the proper Camellia compost. In the autumn, the sorts which it is intended to have stools of are selected, each turned out of its pot, and planted in the centre of the bed. The shoots which cannot be brought in a posture for laying, are to be cut off, and used for cuttings. The other shoots, of not more than two years 
growth, are then to be taken, and tongued about two thirds through, and secured, with a wooden peg, an inch below the surface of the earth. In this state they must remain until they have made sufficient roots to support them, when cut off from the parent plant. When removed, it is advisable to shorten the head of each a little, and to keep them for a few days in a close frame, until they have struck root again. The stools are then to be properly cleaned, the decayed parts cut away, and the soil round the roots renewed, if required.

By Inarching, or Grafting.- - This is the usual mode of propagating the finer sorts of Camellias, and is to be performed early in spring, when the plants begin to grow. For this purpose, Curtis remarks, the stock, being a plant of the Single-red, or any other robust kind, in a pot, is to be fixed in a convenient resting-place, so contiguous to a young healthy shoot of the preceding year's growth, of the variety you wish to increase, that, by the common mode of tongue-grafting, it can be inserted into a clean part of the side of the stock; and after being firmly bound with bass matting, a small piece of clay may be attached, to exclude air from the wounded part, and over this again, a small covering of damp moss may be tied, to prevent the clay from cracking. The head of the stock should then be shortened, (but not cut off,) so as to cause a greater flow of sap to the graft; and if the stock and graft are free growing, healthy plants, in six weeks or two months the union will be so complete, that the scion may be cut from the parent plant. In this state, it is better to let it continue a week; and, in that time, if the leaves remain unaffected by the separation, the clay and matting may all be removed, and the head of the stock cut off, a few inches above the insertion of the scion. It makes the grafted part look better to bandage a fresh piece of matting round it, which in another month may be finally removed; as, without this precaution, the scion is liable to swell out and become unsightly. At the end of a month, when the adhesion has taken place, it is advisable to slacken the bandage, and bind it again. If the union seems tolerably firm, the matting, with a little damp moss, is all that will be then necessary to secure success. The young plants, when removed, should be placed in a close frame, rather shady than otherwise.

We may here observe, that instead of tongue-grafting, above men- 
tioned, side-grafting is to be preferred, in consequence of the former mode having the effect of weakening the stock. With regard to the period when the union of the scion and the stock has taken place, this will very much depend on circumstances; observation alone can dictate when it is proper to detach the scion from the parent plant, and afterwards remove the clay and bandage from it. There is an evil in allowing either to remain on too long, as well as in taking them off too soon; but it is, perhaps, better to err a little on the former side, than on the latter.

Greffe Blaikie.-Some cultivators adopt a very safe mode of inarching, minutely described in the Gardener's Magazine, vol. iv. p. 7, under the name of Greffe Blaikie. The principal of this method is, that after the scion has been bound by ligatures to the stock in the ordinary way, the inferior part of the scion is plunged in a small phial of water, which from time to time is removed, and the base of the submersed scion renewed, by cutting off its extremity. Mr. Murray, of the Glasgow Botanic Garden, has still a more simple, and equally successful method; which is, instead of using phials of water, to insert the lower extremity of the scion into a small potatoe or turnip.

Mr. Palmer's mode of grafting differs from any other we have seen in use. An account of it was communicated to the Horticultural Society, and is as follows: In May, or July, he selects cuttings of the Single-red, with two or three eyes, and grafts of the varieties intended to be propagated, nearly of equal length, and unites them as is usual in inarching - the base of the cutting being half an inch below the base of the graft. They are then planted in white sand, deep enough to cover half an inch of the graft, and struck under a hand-glass, in the common way. Mr. Palmer is of opinion that one or two seasons, and much trouble may be saved, by propagating Camellias in this manner.

$M r$. Herbert's mode of inarching is novel, and is thus described by him, in a letter to Joseph Sabine, Esq. when secretary of the Horticultural Society, who had the kindness to communicate it to us. "Much the best way," he says, " of inarching Camellias, is when the wood is green. At that time $\mathbf{I}$ have proved that the graft will unite in nineteen days. You lean the green shoot against a stock, and inarch the top bud; in about nineteen days, that is to say, the moment the green 
wood turns brown, you cut it off, and cover over the wound. The best covering is the moist dying leaf of a Hippeastrum. Immediately inarch the second bud; in nineteen days more cut it off and inarch the third bud, and so on. These single buds make vigorous shoots the next spring.

Either of the above modes of inarching or grafting may be adopted, according to the fancy of the operator. The one, however, most commonly followed, is that which we have first described.

By Budding.-This method is often resorted to by cultivators, when they have a scarce variety of great value, which they wish to increase rapidly; as a shoot with five or six eyes, which would only have made one plant by being inarched or grafted, will probably make four or five plants by budding, if the operation las been cleverly performed. It is only in particular cases when this mode is advisable; and, even then, it is necessary to be done with great care, and by an experienced cultivator. The time which they take to make good-sized plants is also against the plan of propagating them from buds, as the stock, if budded, will require a year and a half to be equally as forward as the same stock, if it had been grafted.

By Cuttings. - All the sorts of Camellias will strike from cuttings, but some are much more easily struck than others. In this class may be mentioned the Single-red, and Middlemist's Red, which will grow faster than any other kind whatever. The Double-white and the Myrtle-leaved are among the most difficult to strike, but, when obtained in this manner, they always make the handsomest plants. The best time for selecting the cuttings is in the autumn, when the young shoots are sufficiently ripe at the base. They are to be carefully prepared, by being cut smoothly over with a sharp knife at a joint, and divested of one or two leaves at the bottom, (but not shortening any, as is practised by some, ) and then planted firmly, about two inches deep, into flat pans, or wide thirty-two sized pots, filled with pure white sand, four of which can be covered by a common hand-glass. They should afterwards be well watered, and plunged in mould, not tan, in the propagating house, which ought to be kept moist, and shaded for two or three months, but not too warm, as that will endanger the whole. In this situation they will only require to have the glasses occasionally 
wiped. The following February they will be partially rooted, and beginning to grow ; when it is considered that they are sufficiently well rooted to bear removal, which will probably be about August or September, they must be potted off singly into sixty sized pots, well drained, and filled with a compost of one third light loam, one third bog or peat earth, and one third pure white sand. Afterwards they are to be sprinkled with water, and placed in a close frame, or pit, until they begin to root afresh, and by degrees exposed to the air. The succeeding season they may be potted in the same soil as the other Camellias, and similarly treated.

Henderson puts in Camellias at any time of the year, excepting when they are making young wood. He puts fifty cuttings in a pot of sand eight inches in diameter, sets them in a cool place in the back of a vinery or peach-house, for a month or six weeks, then plunges them to the brim in a hotbed, where there is a little bottom heat.

\section{TREATMENT OF ESTABLISHED PLANTS.}

The Camellia may be considered as a hardy green-house plant, requiring only a slight protection, like the myrtle, in very severe weather. But although it will thrive with this kind of treatment, yet to grow the varieties in the very best manner, a great degree of care and attention is necessary. They ought to have a house entirely devoted to them, in which they will be seen to more advantage than when mixed among other exotics. Such a house should be rather lofty than otherwise, as the plants never look so well as when six or eight feet high, trained in a conic form, and clothed with branches from the root upwards. If it is possible to set them near the glass, so much the better; in this case they are less liable to have their leaves injured by the sun. None but the best crown or patent glass should be used; where this is not attended to, it is difficult to prevent the leaves being burned or blotched. To obviate this, some cultivators recommend the house to be rather shady, but we think this is not essentially necessary, unless during the time the plants are in flower, when they ought, in addition, to be liberally supplied with water, and have a degree of heat somewhat 
more than is usually given to green-house plants. If this heat is not given in November and December, the plants will not expand their blossoms freely; and if both water and heat are not regularly applied after the blossoming season, vigorous shoots will not be produced. In summer they may either be set out of doors on a stratum of scoriæ, or on a pavement in a sheltered but open situation. At all times attention must be paid to watering them properly, the roots being very apt to get matted in the pots, so as to render the ball of earth impervious to moisture. Hence it is necessary to see that the water poured on the pots moistens all the earth, instead of the web of fibres only. This renders examining the roots, or reducing, and replanting them, at least once a year, a measure almost indispensable.

The proper season for a general shifting is when the young growth has hardened, and the blossom buds for next year can be detected at the extremity of the shoots. After shifting all those that require it, they may be placed in the open air, or retained in the Camellia-house, admitting daily as much air as possible, and occasionally sprinkling them with water over the leaves. Where there are conveniences for giving the plants different degrees of temperature, a succession of flowers may be had during all the year; but their natural time of flowering is in the months of February, March, and April. They generally flower best when grown in small pots or tubs. Some of the sorts, such as the Double-white, Double-red, and Lady Hume's Blush, are liable to shed their buds from no apparent cause; but we think it frequently arises from the plants being improperly watered, or exposed to too high a temperature.

The most common disease which affects Camellias and renders them unsightly, is the curl in the leaves. This is occasioned by a small black insect, about the size of the green fly, and similar to it in its form. They generally make their appearance on the underside of the young leaves, in the months of April and May, and soon infest the whole of the plants in a collection, unless measures are speedily taken to destroy them. The shoots and leaves are often covered with their excrescence, which is sweet and viscid, resembling what is familiarly known by the name of honey-dew. As soon as there is the least appearance of the insects upon the plants, the house should be subjected to a 
powerful smoking with tobacco in the evening, and the following morning syringed with soft water very early, or at least before the sun is of sufficient strength to do any injury to the leaves. Once smoking is all that will be necessary; but for this and similar operations, no fixed rules can be laid down. Experience and observation alone must be our guide.

END OF VOL. I.

C. BAYNES, PRINTER,

13, DURE-STREET, LINCOLN'S IVY FIELDS. 

LLOYD LIBRARY \& MUSEUM

917 PLUM STREET

CINCINNATI, OHIO 45202 USA 
20
413
015
4495
1831
$R 5 R$
$(6)$ 


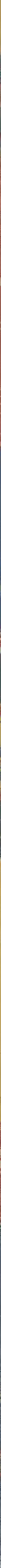


